Universidade de Brasília

Instituto de Ciências Biológicas

Departamento de Botânica

Programa de Pós Graduação em Botânica

Dissertação de Mestrado

Anatomia foliar de Allagoptera Nees (Arecaceae) como subsídio à taxonomia

André Silva Pinedo

Orientadora: Prof ${ }^{a}$ Dr $^{a}$ Sueli Maria Gomes

Brasília, março de 2015 
Universidade de Brasília

Instituto de Ciências Biológicas

Departamento de Botânica

Programa de Pós Graduação em Botânica

Dissertação de Mestrado

Anatomia foliar de Allagoptera Nees (Arecaceae) como subsídio à taxonomia

Dissertação apresentada ao Programa de PósGraduação em Botânica da Universidade de Brasília como um dos requisitos para obtenção do título de Mestre em Botânica.

André Silva Pinedo

Orientadora: Prof ${ }^{a}$ Dr $^{a}$ Sueli Maria Gomes

Brasília, março de 2015 
Universidade de Brasília

Instituto de Ciências Biológicas

Departamento de Botânica

Programa de Pós Graduação em Botânica

Banca examinadora:

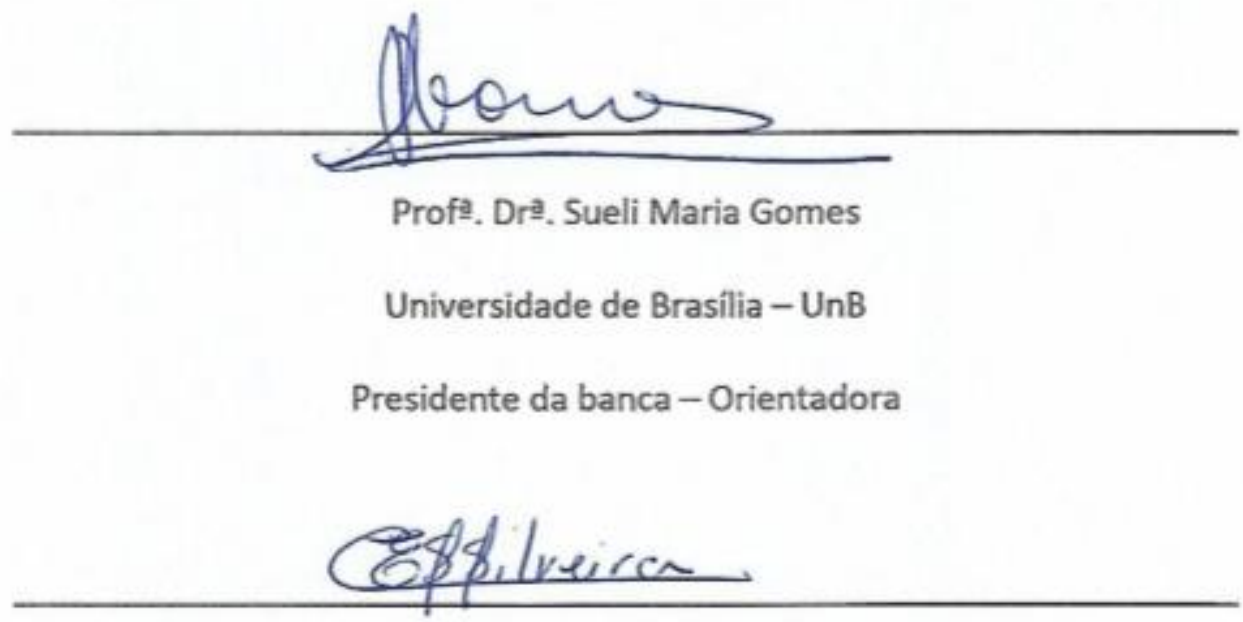

Profa. Dra . Conceição Eneida dos Santos Silveira

Universidade de Brasilia - UnB

Examinador interno

Profa. Drà. Julia Sonsin Oliveira
Universidade de Brasilia - UnB
Examinador externo

Prof. Dr. Luiz Alfredo Rodrigues Pereira

Universidade de Brasilia - UnB

Suplente 


\section{$A_{\text {gradecimentos }}$}

Primeiramente a Deus, sou eternamente grato pela minha vida, pela oportunidade proporcionada e pela capacitação de estar realizando este curso de pós-graduação, que tem sido uma grande experiência de amadurecimento para mim;

À minha orientadora, Profạ. Drạ. Sueli Maria Gomes, pela sua paciência ao me ensinar e constantes críticas construtivas que fez ao longo do período em que trabalhamos juntos, que fizeram desse mestrado uma grande oportunidade para o meu crescimento profissional;

À Profa. Drạ. Renata Corrêa Martins, por sua parceria nesse projeto, auxiliando na coleta e identificação das espécies, além de ser uma profissional extremamente prestativa;

À Profa. Dra. . Cássia Munhoz, minha orientadora em estágio de Iniciação Científica na graduação, motivando-me a trabalhar com plantas;

Ao Prof. Dr. Eduardo Gomes Gonçalves, por ter me incentivado a trabalhar com o grupo das palmeiras;

À Profạ. Drạ. Micheline Carvalho, por me instruir sobre a metodologia básica de coleta de material anatômico;

A todos os demais docentes do Programa de Pós Graduação de Botânica da UnB, por terem me aberto portas e me mostrado caminhos em que pude confiar;

Aos discentes do Programa de Pós Graduação de Botânica da UnB e participantes do Programa Institucional de Bolsas de Iniciação Científica - PIBIC, por seus auxílios e conselhos nos momentos em que precisei;

Aos curadores e funcionários dos herbários analisados no DF (IBGE, CEN, HEPH e UB), por se mostrarem acessíveis e prestativos nos momentos em que necessitei;

Aos técnicos e estagiários do laboratório de Anatomia Vegetal da UnB - Daiane Veras, Bernardo Kruchak, Cristianini Rodor, Jéssika Vieira, Lucas Paiva, Annie de Lima e Amanda Nunes - e aos demais técnicos e funcionários do Instituto de Biologia da UnB, sou grato por todo auxílio proporcionado, por tudo que aprendi e por toda a paciência, compreensão e momentos de descontração, além de terem me ensinado que a essência do meu mestrado não se encontra apenas no trabalho em si, mas também no 
conviver e no ter de lidar com diferentes situações a cada dia, o que tornou esse período da minha vida uma verdadeira escola de aprendizado;

A Profa. Dra. Rita Portela (UFRJ), por tornar possíveis as coletas das espécies que ocorrem no litoral;

Ao mateiro Adilson e ao motorista Wando Mendes, por sua disposição em acompanhar algumas coletas, tendo auxiliado a realizá-las;

Aos herbários Alexandre Leal Costa (ALCB - BA) e Universidade Estadual de Feira de Santana (HUEFS - BA), pelo empréstimo de material e autorização da retirada de pequenos segmentos foliares das exsicatas para realização dos estudos anatômicos;

À Fundação Capes, pelo auxílio financeiro proporcionado;

Aos membros da banca avaliadora - Conceição Eneida, Júlia Oliveira e Luiz Pereira -, por terem disposto de seu tempo para elaborar críticas construtivas a este projeto, auxiliando assim meu progresso como profissional qualificado;

À minha família, especialmente aos meus pais, Luiz Pinedo e Lúcia Silva, e à minha irmã, Carolina Pinedo, sem os quais não teria sequer chegado até aqui;

Aos meus tios, Tom Polacheck, Cristina Pinedo, Moacyr Neto e Olinda Silva, por seu companheirismo, críticas e sugestões aos meus trabalhos;

Aos meus avós, Helion Moreira, Laura Silva, Alberto Pinedo e Walkyria Pinedo, que permanecerão para sempre no meu coração por serem exemplos de pessoas;

Aos meus primos, Mariana Altenberd e Raphaello Mazzei, cujas vidas têm me servido de modelo sobre como superar diferentes desafios;

À minha psicóloga, Martha Briski, por ter sido a principal catalisadora do meu processo de amadurecimento;

Aos meus amigos e irmãos da Igreja Atos de Vida - a todos, mas especialmente a Vinícius Carolino, André Carolino e Noel Eudes - por eu poder encontrar a verdadeira essência da felicidade junto a vocês, pelo incentivo que me deram para mudar meu jeito de ser e por estarem presentes em alguns dos momentos mais difíceis da minha vida;

Aos meus amigos de Ensino Fundamental e Médio - Douglas Pitombo, Philipp Meyer, Gabriel Barros, Pedro Ghiraldini, Alex Almeida, Rodrigo Fernandes e Luiz Eduardo -, pela amizade de muitos anos cultivada;

A Carolina Vasconcelos e aos meus amigos do Studio Mariana Falcão e do Studio Bom Dia Pilates - Natália Ferreira, Mariana Falcão, Vinícius Falcão, Igor Eduardo e Talita Flausino -, por sempre me instruírem que o bem estar envolve não apenas a parte intelectual, mas também a parte física do corpo; 
A Andrea Sacco, por sua amizade e por seu incentivo aos meus estudos;

A todas as pessoas que passaram pela minha vida deixando marcas negativas, por terem me ajudado a amadurecer por meio dos eventuais problemas e conflitos gerados.

A todos, o meu muito obrigado! 
"Consagre ao Senhor

tudo o que você faz, e os seus planos serão bem sucedidos"

Provérbios 16, 3 


\section{$\mathbf{S}_{\text {umirio }}$}

$\begin{array}{lr}\text { Resumo } & 1\end{array}$

$\begin{array}{lr}\text { Abstract } & 2\end{array}$

Introdução geral 3

Referências bibliográficas 5

\section{Capítulo I - Anatomia foliar de Allagoptera Nees (Arecaceae)}

Resumo
Abstract
Introdução

$\begin{array}{ll}\text { Importância de Arecaceae } & 11\end{array}$

$\begin{array}{ll}\text { Morfologia de Allagoptera Nees } & 13\end{array}$

$\begin{array}{ll}\text { Anatomia de Arecaceae } & 14\end{array}$

$\begin{array}{ll}\text { Revisão bibliográfica } & 15\end{array}$

$\begin{array}{ll}\text { Arecoideae Burnett } & 15\end{array}$

$\begin{array}{ll}\text { Cocoseae Mart. } & 16\end{array}$

$\begin{array}{ll}\text { Attaleinae Drude } & 16\end{array}$

$\begin{array}{ll}\text { Allagoptera Nees } & 17\end{array}$

$\begin{array}{ll}\text { Fórmula Vascular } & 17\end{array}$

$\begin{array}{ll}\text { Hipóteses } & 18\end{array}$

$\begin{array}{ll}\text { Objetivos } & 18\end{array}$

$\begin{array}{ll}\text { Objetivo geral } & 18\end{array}$

$\begin{array}{ll}\text { Objetivos específicos } & 18\end{array}$ 
Cortes paradérmicos

Análise dos dados e terminologias

Resultados

Adequação metodológica

Descrição anatômica

Allagoptera Nees

Allagoptera arenaria (Gomes) Kuntze

Allagoptera brevicalyx M. Moraes

Allagoptera campestris (Mart.) Kuntze

Allagoptera caudescens (Mart.) Kuntze

Allagoptera leucocalyx (Drude) Kuntze

Allagoptera robusta R. C. Martins \& Filg. 
Capítulo II - Filogenia de Allagoptera Nees (Arecaceae) com base em dados morfoanatômicos

Resumo

Abstract

Introdução

Hipóteses

Objetivos

Objetivo geral

66

Objetivos específicos

66

Material e métodos

67

Análise filogenética

67

Resultados

Discussão

Conclusão

Referências bibliográficas

Anexo 


\section{§ Lista de figuras (Fig.)}

\section{Capítulo I - Anatomia foliar de Allagoptera Nees (Arecaceae)}

Fig. 1. Exemplo da metodologia realizada para os estudos anatômicos em uma espécie

Fig. 2. Esquema ilustrando as diferenças morfológicas entre as margens foliares

Fig. 3. Anatomia foliar de Allagoptera arenaria (Gomes) Kuntze (Restinga)

Fig. 4. Anatomia foliar de Allagoptera brevicalyx M. Moraes (Restinga)

Fig. 5. Anatomia foliar de Allagoptera campestris (Mart.) Kuntze (Cerrado)

Fig. 6. Anatomia foliar de Allagoptera caudescens (Mart.) Kuntze (Mata Atlântica)

Fig. 7. Anatomia foliar de Allagoptera leucocalyx (Drude) Kuntze (Cerrado)

Fig. 8. Anatomia foliar de Allagoptera robusta R. C. Martins \& Filg. (Cerrado)

Fig. 9. Análise histoquímica de compostos fenólicos em Allagoptera (Arecaceae)

Fig. 10. Análise histoquímica de taninos em Allagoptera (Arecaceae)

Fig. 11. Fórmulas Vasculares (FV) obtidas para as espécies de Allagoptera (Arecaceae)

Fig. 12. Esquemas Vasculares (EV) obtidos para as espécies de Allagoptera (Arecaceae)

Capítulo II - Filogenia de Allagoptera Nees (Arecaceae) com base em dados morfoanatômicos

Fig. 1. Relações de parentesco entre as subfamílias de Arecaceae

Fig. 2. Relações entre as subtribos e tribos da subfamília Arecoideae

Fig. 3. Árvore filogenética de Allagoptera Nees (Arecaceae), com base em 154 caracteres morfoanatômicos

Fig. 4. Distribuição geográfica de Allagoptera Nees (Arecaceae) pelo território brasileiro 
§ Lista de tabelas

Capítulo I - Anatomia foliar de Allagoptera Nees (Arecaceae)

Tabela 1. Vouchers das espécies de Allagoptera Nees (Arecaceae) analisadas quanto a sua anatomia foliar

Tabela 2. Símbolos e letras utilizados na Fórmula Vascular (FV) e seus respectivos significados

Tabela 3. Lista de símbolos utilizados no Esquema Vascular (EV) e seus respectivos significados 26

Capítulo II - Filogenia de Allagoptera Nees (Arecaceae) com base em dados morfoanatômicos

Tabela 1. Caracteres morfoanatômicos analisados pelo software PAST para Allagoptera Nees (Arecaceae) e para Phytelephas macrocarpa Ruiz \& Pav. (grupo externo, Arecaceae) 


\section{$\mathbf{R}_{\text {esuma }}$}

O gênero Allagoptera, pertencente à família Areaceae (Cocoseae, Attaleinae), é constituído por seis espécies ainda pouco exploradas quanto à anatomia foliar. Neste estudo, foi realizada uma descrição detalhada da anatomia foliar de todas as espécies de Allagoptera, bem como uma análise das relações filogenéticas entre as mesmas. Secções paradérmicas e cortes transversais dos segmentos foliares foram obtidos, tendo estes últimos sido realizados em micrótomo de mesa. Os caracteres anatômicos foram observados e registrados sob fotomicroscópio com sistema de captura de imagens. As descrições anatômicas foram utilizadas para a elaboração de uma chave de identificação. Considerando a peculiaridade anatômica do mesofilo observado em algumas espécies, é proposta uma nova categoria de classificação, denominada mesofilo dorsiventral gradativo. Diferentemente do mesofilo homogêneo - onde não há variação significativa no tamanho das células - e do mesofilo dorsiventral - onde há duas camadas de parênquima bem definidas -, no mesofilo dorsiventral gradativo há uma variação gradativa no tamanho das células do mesofilo. A abundância de compostos fenólicos no mesofilo é uma característica do gênero, que parece realocar grande parte de seus recursos para a defesa contra possíveis herbívoros. Observou-se a presença de bordos salientes nas células subsidiárias, uma característica anatômica ainda não descrita na literatura e aqui denominada cristas subsidiárias, em analogia às cristas estomáticas. É também apresentado um Esquema Vascular (EV) para a representação da anatomia foliar das plantas estudadas, com base na Fórmula Vascular (FV) que tem sido aplicada às gramíneas. Ambas as ferramentas provaram ser úteis para a distinção e comparação das espécies analisadas. A filogenia do gênero, baseada em caracteres morfo-anatômicos, destacou como espécies mais basais $A$. caudescens e $A$. arenaria. Tendo em vista que as espécies mais basais se restringem às regiões litorâneas brasileiras, o gênero possivelmente se originou neste ambiente, conquistando gradualmente biomas mais interioranos do continente sul americano.

Palavras-chave: Esquema Vascular, Fórmula Vascular, filogenia, fitogeografia, histoquímica. 


\section{$A_{\text {bstract }}$}

The genus Allagoptera, belonging to the family Arecaceae (Cocoseae, Attaleinae), is comprised by six species still little explored as to the leaf anatomy. In this study, a detailed description of the leaf anatomy of all Allagoptera species was accomplished, as well as an analysis of the phylogenetic relationships between them. Paradermic and transverse sections of the leaf segments were obtained, the later ones accomplished in a table microtome. The anatomic characters were observed and registered under photomicroscope with image capture system. The anatomical descriptions were used to the elaboration of an identification key. Given the anatomical peculiarity of the mesophyll observed in some species, a new classification category called gradative dorsiventral mesophyll is proposed. Differently from the homogeneous mesophyll - where there is no significant variation in the cell sizes and the dorsiventral mesophyll - where there are two parenchyma layers clearly defined -, in the gradative dorsiventral mesophyll there is a gradative variation in the mesophyll cell sizes. The abundance of phenolic compounds in the mesophyll is a genus characteristic, which seems to relocate much of their resources for defence against potential herbivorous. The presence of prominent sides on the subsidiary cells was observed, an anatomical characteristic still not described in the literature and called here as subsidiary ledges, in analogy to the stomatal ledges. The Vascular Scheme (VS) is also presented to the representation of the leaf anatomy of the studied plants, based on the Vascular Formula (VF), which has been applied to grasses. Both tools have proven useful for the distinction and comparison of the analysed species. The phylogeny of the genus, based on morphological and anatomical characters, highlighted $A$. caudescens and $A$. arenaria as the most basal species. In view of the most basal species are restricted to the Brazilian coastal regions, the genus possibly was originated in this environment, conquering gradually more landlocked biomes of the South American continent.

Key-words: Vascular Scheme, Vascular Formula, phylogeny, phytogeography, histochemistry. 


\section{Introdução geral}

Em termos gerais, a anatomia pode ser definida como o estudo da estrutura interna de um organismo. Nesse sentido, três tipos distintos de anatomia podem ser diferenciados: humana, animal e vegetal. O desenvolvimento do microscópio óptico, que ocorreu no final do século XVI e no início do século XVII, revolucionou toda a área da anatomia, tornando-a mais refinada como ciência moderna (Bolam, 1973).

Dentro desse contexto, a busca por uma compreensão de como os diferentes tecidos que constituem o corpo de um vegetal se organizam espacialmente foi se desenvolvendo. No século XVII, Macello Malpighi e Nehemiah Grew foram considerados os fundadores da anatomia vegetal, com as obras mais influentes na área desde os tempos de Aristóteles (Bolam, 1973). Porém, foi no século XIX com cientistas como Charles-François Brisseau de Mirbel, Johann Jacob Paul Moldenhawer e Franz Meyen que este ramo da ciência foi se estruturando (Reed, 1942). Dessa maneira, a anatomia vegetal passou a constituir uma área da ciência não somente descritiva, mas também experimental, juntamente com a genética e a fisiologia vegetal (Dengler, 2002).

A revolução filogenética, iniciada na década de 1980, transformou a biologia sistemática de tal modo que grande parte dos estudos realizados nesta área incluem um componente filogenético (Dransfield et al., 2008). Estudos filogenéticos têm se mostrado imprescindíveis para a definição de grupos taxonômicos (Chase et al., 2000; Chase, 2004; APG III, 2009; Seberg et al., 2012).

Simultaneamente a essa revolução, cientistas passaram a aplicar dados do DNA e RNA para a execução da sistemática, originando a sistemática molecular. Com esta técnica, viabilizou-se a comparação entre organismos de uma maneira mais simples e rápida (Raven et al., 2007). No entanto, é importante ressaltar que os dados moleculares não atuam independentemente na resolução de filogenias. Os dados morfológicos, anatômicos, palinológicos, fisiológicos, embriológicos e cromossômicos, dentre outros, devem ser analisados em conjunto com os dados moleculares para se chegar a um consenso sobre um determinado grupo taxonômico (Judd et al., 2009).

A anatomia pode ser uma ferramenta promissora, auxiliando a definir o posicionamento de grupos taxonômicos morfológica e ecologicamente semelhantes, como as espécies da família Cyperaceae (Hefler \& Longhi-Wagner, 2010). Para a ordem Myrtales, a anatomia também tem desempenhado importante papel taxonômico por meio da construção de cladogramas e chaves de 
identificação anatômicas, além de tornar possível levantar hipóteses sobre a ecologia e a evolução dos diferentes grupos (Kantachot et al., 2007; Gomes et al., 2009).

Para a família Arecaceae Bercht. \& J. Presl. (= Palmae Juss.), grupo pouco distinto morfologicamente, a anatomia tem se apresentado como importante alternativa para a elaboração de taxonomias mais robustas (Horn et al., 2009). Em um importante estudo com a anatomia radicular de 101 gêneros de palmeiras, Seubert (1998) relacionou seus resultados com análises morfológicas já existentes, contribuindo para a taxonomia do grupo. Outro estudo, realizado apenas com palmeiras fitelefantoides (gêneros Phytelephas Ruiz \& Pav., Palandra O. F. Cook e Ammandra O. F. Cook), Barfod (1988) relacionou aspectos anatômicos com aspectos morfoecológicos para definir uma taxonomia.

Arecaceae (cerca de 2.700 espécies; Lorenzi, 2010) ainda apresenta lacunas no conhecimento científico, podendo estas ser atribuídas principalmente à dificuldade de coleta da maioria das espécies. A metodologia de coleta das palmeiras já é bem conhecida, contando com guias e roteiros de coleta (Dransfield, 1986; Martins \& Filgueiras, 2010). No entanto, essas mesmas obras afirmam que o processo de coleta de uma palmeira exige esforço e requer aptidão e disposição do coletor. Essas afirmações indicam que, apesar da abundância de espécies na natureza, o registro nos herbários é relativamente limitado. Além disso, conforme já observado por alguns autores (Dransfield et al., 2008; Horn et al., 2009), a separação entre gêneros e espécies é uma tarefa mais criteriosa quando aspectos morfológicos são analisados em conjunto com características não-morfológicas.

Apesar desses e de outros trabalhos, Tomlinson et al. (2011) observam que muitos gêneros de Arecaceae ainda não são bem compreendidos em termos anatômicos. Estes mesmos autores apontam Arecoideae Burnett, a subfamília mais diversificada dentro de Arecaceae (14 tribos e 97 gêneros), como aquela em que há uma maior necessidade de estudos. Com efeito, a análise dos trabalhos realizados para essa subfamília até o ano de 2008 indica que mais de um quarto dos gêneros já foram estudados sob algum aspecto anatômico (anatomia da raiz, do estipe, da flor e/ou do fruto), porém ainda não quanto a sua anatomia foliar (Dransfield et al., 2008).

Conforme ressaltado, há uma carência de estudos anatômicos para a tribo Cocoseae Mart., o que representa uma lacuna para a taxonomia da subfamília Arecoideae e da família Arecaceae em geral. Um dos grupos que têm sido pouco explorados é o gênero Allagoptera Nees. Para as espécies desse grupo, a revisão taxonômica de Moraes (1996) continua sendo a obra mais completa e atualizada, muito embora duas novas espécies - A. caudescens Mart. (Kuntze) e A. robusta R. C. Martins \& Filg. - tenham sido acrescentadas ao gênero desde então (Dransfield et al., 2005; Martins et al., 2015).

Uma fórmula vascular, proposta inicialmente para distinguir gêneros e espécies de gramíneas (Silva, 2012), também tem se mostrado aplicável a palmeiras (Gomes \& Borges, 2013). Dessa maneira, buscou-se com este estudo compreender a anatomia foliar de Allagoptera e, com base nos caracteres anatômicos observados, montar uma chave de identificação e traçar a filogenia do gênero. 


\section{$\mathbf{R}_{\text {eferencias biblibograficas }}$}

APG III. 2009. An update of the Angiosperm Phylogeny Group classification for the orders and families of flowering plants: APG III. Botanical Journal of the Linnean Society 141:399-436.

Barfod, A. 1988. Leaf anatomy and its taxonomic significance in phytelephantoid palms (Arecaceae). Nordic Journal of Botany, 8(4):341-348.

Bolam, J. 1973. The botanical works of Nehemiah Grew, FRS (1641-1712). Notes and Records of the Royal Society of London, 219-231.

Chase, M. W., De Bruijn, A. Y., Cox, A. V., Reeves, G., Rudall, P. J., Johnson, M. A., Eguiarte, L. E. 2000. Phylogenetics of Asphodelaceae (Asparagales): an analysis of plastid rbcL and trnL-F DNA sequences. Annals of Botany, 86(5):935-951.

Chase, M. W. 2004. Monocot relationships: an overview. American Journal of Botany, 91(10):16451655.

Dengler, N. G. 2002. An integral part of botany. American Journal of Botany, 89(2):369-374.

Dransfield, J. 1986. A guide to collecting palms. Annals of the Missouri Botanical Garden, 73:166-176.

Dransfield, J., Uhl, N. W., Asmussen, C. B., Baker, W. J., Harley, M. M., Lewis, C. E. 2005. A new phylogenetic classification of the palm family, Arecaceae. Kew Bulletin, 60:559-569.

Dransfield, J., Uhl, N. W., Asmussen, C. B., Baker, W. J., Harley, M. M., Lewis, C. E. 2008. Genera Palmarum. Royal Botanic Gardens Kew, Kew UK.

Gomes, S. M., Borges, J. B. 2013. Fórmula vascular (FV) na descrição anatômica foliar de Syagrus glazioviana (Arecaceae). 64 Congresso Nacional de Botânica. 10 a 15 de Novembro de 2013: Belo Horizonte.

Gomes, S. M., Somavilla, N. S. D. N., Gomes-Bezerra, K. M., Miranda, S. D. C. D., Carvalho, P. S., Graciano-Ribeiro, D. 2009. Leaf anatomy of Myrtaceae species: contributions to the taxonomy and phylogeny. Acta Botanica Brasilica, 23(1):224-238.

Hefler, S. M., Longhi-Wagner, H. M. 2010. Contribution of leaf anatomy to the taxonomy Cyperus L. subg. Cyperus (Cyperaceae) species from southern Brazil. Acta Botanica Brasilica, 24(3):708-717.

Horn, J. W., Fisher, J. B., Tomlinson, P. B., Lewis, C. E., Laubengayer, K. 2009. Evolution of lamina anatomy in the palm family (Arecaceae). American journal of Botany, 96(8):1462-1486. 
Judd, W. S., Campbell, C. S., Kellog, E. A., Stevens, P. F., Donoghue, M. J. 2009. Sistemática vegetal: um enfoque filogenético. Editora Artmed: São Paulo.

Kantachot, C. H. O. R. T. I. P., Chantaranothai, P. R. A. N. O. M., Thammathaworn, A. C. H. R. A. 2007. Contributions to the leaf anatomy and taxonomy of Thai Myrtaceae. The Natural History Journal of Chulalongkorn University, 7(1):35-45.

Lorenzi, H. 2010. Flora brasileira: Arecaceae (Palmeiras). Instituto Plantarum de Estudos da Flora.

Martins, R. C., Filgueiras, T. S. 2010. Roteiro morfológico para coleta de palmeiras no Cerrado. Heringeriana, 4(1):51-59.

Martins, R. C., Filgueiras, T. S., Graciano-Ribeiro, D., Somavilla, N. S. 2015. A new species of Allagoptera (Arecaceae) from the Cerrado of central Brazil. Phytotaxa, 197(2):115-124.

Moraes, M. 1996. Allagoptera (Palmae). Flora Neotropica, 73:1-34.

Raven, P. H., Evert, R. F., Eichhorn, S. E. 2007. Biologia Vegetal. Sétima Edição. Editora Guanabara Koogan: Rio de Janeiro.

Reed, H. S. 1942. A Short History of the Plant Sciences. New York: Ronald Press.

Seberg, O., Petersen, G., Davis, J. I., Pires, J. C., Stevenson, D. W., Chase, M. W., Fay, M. F., Devey, D. S., Jørgensen, T., Sytsma, K. J., Pillon, Y. 2012. Phylogeny of the Asparagales based on three plastid and two mitochondrial genes. American Journal of Botany, 99(5):875-889.

Seubert, E. 1998. Root anatomy of palms IV. Arecoideae, part 2, Systematic implications. Feddes Repertorium, 109(1-2):89-127.

Silva, A. L. H. D. 2012. Anatomia do colmo e lâmina foliar de espécies de Paspalum L.(Poaceae: Panicoideae: Paniceae): novos caracteres taxonômicos e proposta de uma fórmula vascular para representação dos feixes vasculares da lâmina foliar. Brasília, Instituto de Ciências Biológicas, Departamento de Botânica da Universidade de Brasília. 86 p. Dissertação de Mestrado.

Tomlinson, P. B., Horn, J. W., Fisher, J. B. 2011. The anatomy of palms. Arecaceae - Palmae. USA: Oxford University Press. 


\section{Capítulo I}

Anatomia foliar de Allagoptera Nees (Arecaceae) 
Allagoptera é um gênero que pertence à família Arecaceae composto por quatro espécies, tendo duas novas espécies - $A$. caudescens e $A$. robusta - sido acrescentadas a essa lista. $O$ gênero pode ser utilizado para fins alimentícios e ornamentais, com algumas espécies relevantes na medicina, no artesanato e na indústria. Allagoptera ainda apresenta grandes lacunas quanto à sua anatomia, apesar de algumas espécies de Arecaceae já terem sido satisfatoriamente abordadas quanto a este quesito. 0 objetivo desse estudo foi descrever a anatomia foliar das espécies de Allagoptera e identificar caracteres úteis à taxonomia do gênero. Quatro espécimes de cada espécie foram coletados. Secções transversais foram efetuadas em micrótomo de mesa no terço mediano dos segmentos foliares. Cortes paradérmicos foram obtidos por dissociação ácida. As imagens foram registradas em fotomicroscópio associado ao computador. Caracteres comuns a todas as espécies foram presença de papilas em uma ou em ambas as faces foliares, grupos de fibras restritos à face adaxial, células buliformes restritas à face abaxial, células do mesofilo com compostos fenólicos abundantes e feixes vasculares envolvidos por uma bainha esclerenquimática, confirmando os dados da literatura. Os feixes vasculares de terceira e quarta ordens apresentaram-se ligados abaxialmente por grupos de fibras para a maioria das espécies, enquanto os feixes de primeira e segunda ordens ligaram-se a ambas as faces por extensões da bainha do feixe. O mesofilo variou de dorsiventral (em A. brevicalyx) a homogêneo (em A. robusta). No entanto, constatou-se que, em algumas espécies, a altura das células variou muito no mesmo mesofilo. É proposta uma nova classificação do mesofilo em dorsiventral clássico, presente em A. brevicalyx e $A$. caudescens, e dorsiventral gradativo, que ocorreu em A. arenaria e A. leucocalyx. Uma padronização da terminologia "células buliformes", utilizada para Poaceae, é também sugerida, bem como a aplicação do nome "cristas subsidiárias" para denominar projeções observadas nas células subsidiárias. Com base na Fórmula Vascular, um Esquema Vascular é proposto para esquematizar a disposição dos feixes vasculares na lâmina, tendo ambos se mostrarado aplicáveis às espécies e sintetizado os caracteres anatômicos. O formato, a frequência e o número de fibras em cada grupo, o padrão vascular e o formato dos grupos de fibras marginais foram caracteres que variaram entre as espécies do gênero, constituindo bons caracteres para uso taxonômico. Os caracteres anatômico-foliares distinguiram as espécies de Allagoptera e, quando interpretados de acordo com o ambiente de cada uma das espécies, acrescentam informações relevantes ao conhecimento de Arecaceae.

Palavras-chave: caracteres anatômicos, classificação do mesofilo, fórmula vascular. 
Allagoptera is a genus which belongs to the family Arecaceae composed by four species, and two new species - A. caudescens and $A$. robusta - were added to this list. The genus can be used for food and ornamental purposes, with some species important in the medicine, in the handicraft and in the industry. Allagoptera still presents great gaps as to its anatomy, although some Arecaceae species have already been satisfactorily addressed as to this issue. The objective of this study was to describe the leaf anatomy of Allagoptera species and identify useful characters to the genus taxonomy. Four specimens of each specie were collected. Transverse sections were performed on a table microtome in the middle third of the leaf segments. Paradermic sections were obtained by acid dissociation. The images were registered on a photomicroscope associated to the computer. Characters shared by all Allagoptera species were presence of papillae in one or in both leaf faces, fiber groups restricted to the adaxial surface, bulliform cells restricted to the abaxial surface, mesophyll cells with abundant phenolic compounds and vascular bundles involved by a schlerenchymatic sheath, confirming the literature data. The vascular bundles of third and fourth orders were connected abaxially by fiber groups for most of the species, while the bundles of first and second orders were connected to both faces by bundle sheath extensions. The mesophyll varied from dorsiventral (in A. brevicalyx) to homogeneous (in A. robusta). However, it was observed that, in some species, the height of the cells varied greatly on the same mesophyll. It is proposed a new classification of the mesophyll in dorsiventral classical, present in $A$. brevicalyx and A. caudescens, and dorsiventral gradative, which ocorred in A. arenaria and A. leucocalyx. A standardization of the terminology "bulliform cells", used for Poaceae, is also suggested, as well as the application of the name "subsidiary ridges" to denominate projections observed on the subsidiary cells. Based on the Vascular Formula, a Vascular Scheme is proposed to diagram the vascular bundles disposition in the lamina, and both showed to be applicable to the species and synthetized the anatomical characters. The shape, the frequency and the number of fibers on each group, the vascular pattern and the shape of the marginal fiber groups were characters that varied among the species of the genus, constituting good characters for taxonomic use. The leaf anatomical characters distinguished the Allagoptera species and, when interpreted according to each species environment, add relevant informations to Arecaceae knowledge.

Key-words: anatomical characters, mesophyll classification, Vascular Formula. 


\section{ntrodução}

As monocotiledôneas constituem um grupo de angiospermas reconhecido desde o século XVII, cuja principal característica é a presença de um único cotilédone (Chase, 2004). Embora com menos famílias que as eudicotiledôneas, as monocotiledôneas apresentam extrema importância, principalmente pela ampla utilização agrícola e ornamental, bem como para fins medicinais e forrageiros (Souza \& Lorenzi, 2012).

Dentre as monocotiledôneas, Poaceae Barnhart (= Gramineae Juss.) destaca-se pela sua ampla utilização agrícola e forrageira (Raven et al., 2007). A presença das gramíneas é cada vez mais evidente em nosso dia-a-dia, haja vista a abundância de alimentos à base de milho (Zea mays L.), trigo (Triticum aestivum L.), arroz (Oryza sativa L.), sorgo (Sorghum bicolor (L.) Moench), cana-de-açúcar (Saccharum officinarum L.), centeio (Secale cereale L.) e aveia (Avena sativa L.), além de espécies utilizadas como forrageiras em pastagens.

Araceae Juss. é outra família de monocotiledôneas que se destaca pela sua diversidade e pelo seu potencial ornamental. Muitas espécies, como o antúrio (Anthurium sp. Schott), o filodendro (Philodendron sp. Schott), o copo-de-leite (Zantedeschia aethiopica (L.) Spreng.), a costela-de-adão (Monstera deliciosa Liebm.) e a jiboia (Epipremnum pinnatum Schott) são utilizadas no paisagismo (Souza \& Lorenzi, 2012).

Juntamente com as famílias Poaceae e Araceae, Arecaceae Bercht. \& J. Presl (= Palmae Juss.) constitui uma das famílias de monocotiledôneas mais utilizadas e exploradas pelo homem (Lorenzi, 2010; Souza \& Lorenzi, 2012). Arecaceae é o grupo conhecido popularmente por palmeiras ou coqueiros. As espécies do grupo são facilmente reconhecíveis e bem distintas quando comparadas às demais monocotiledôneas, porém as diferenças não são tão evidentes entre as espécies que compõem a família devido à sua grande semelhança morfológica. Há uma estimativa de mais de duas mil espécies de Arecaceae no mundo, das quais aproximadamente 260 são brasileiras (Souza \& Lorenzi, 2012). De acordo com a Flora do Brasil (Leitman et al., 2015), 39 gêneros e 264 espécies ocorrem no país, sendo 108 espécies endêmicas. 


\section{Importância de Arecaceae}

Arecaceae é uma família que se destaca pela importância econômica dos produtos que podem ser obtidos a partir de suas espécies, com usos alimentícios, medicinais, combustíveis, madeireiros e industriais (Balick, 1988; Johnson, 1989; Muñiz-Miret et al., 1996; Mollet et al., 2000; d'Almeida et al., 2006; Zambrana et al., 2007). A família possui ainda uma grande importância ecológica, além de ser utilizada amplamente para fins paisagísticos e ornamentais (Lorenzi, 2010).

Como uso alimentício, merecem destaque palmeiras que produzem um meristema apical comestível - como Euterpe edulis Mart. (palmito) - ou frutos - como Cocos nucifera L. (coqueiro), Elaeis guineenses Jacq. (dendezeiro) e Euterpe oleracea Mart. (açaí) (Souza \& Lorenzi, 2012). Estas duas últimas espécies estão intimamente relacionadas à cultura da região onde ocorrem, sendo o dendê e o açaí marcas culturais dos povos que habitam o nordeste e o norte brasileiro.

Muitas espécies da família são utilizadas contra problemas digestivos, além de servirem como anestésicos para dores agudas (Sosnowska \& Balslev, 2008), sendo o exemplo mais clássico o coqueiro, cuja água é utilizada como purgativo e contra problemas gastrointestinais (Carvalho et al., 2006).

Algumas palmeiras fornecem ainda excelentes alternativas como fontes de energia limpa, merecendo destaque nesse quesito a macaubeira ou macaúba (espécies do gênero Acrocomia Mart.; Aoqui, 2012). O óleo extraído das espécies desse gênero é utilizado na produção de biodiesel, podendo ser uma interessante alternativa às fontes de energia não renováveis (de Melo, 2012; Martins et al., 2014).

Muitas tribos e povos ligados diretamente às florestas tropicais dependem destas plantas. Em um levantamento realizado com 37 espécies de palmeiras da Amazônia Equatorial, constatou-se que todas eram utilizadas pelos povos nativos, tendo como principal importância a construção de casas e o fornecimento de alimentos (Macía, 2004).

Embora ainda pouco exploradas, as fibras de Attalea funifera Mart. ex Spreng. apresentam importantes aplicações industriais, sendo sua composição e suas propriedades comparáveis às fibras de coco (d'Almeida et al., 2006). Estes mesmos autores sugerem ainda que sobras de piassava de $A$. funifera podem ser utilizadas como reforço para materiais compostos com matriz de resina.

Arecaceae pode ainda estar envolvida em importantes processos de conservação ecossistêmicos. No Cerrado, podemos citar como principal exemplo o buriti (Mauritia flexuosa L. f.), espécie que possui potencial para o fornecimento de produtos florestais não madeireiros. É necessária, no entanto, uma exploração controlada destas plantas, visto que a espécie contribui para a manutenção dos recursos hídricos do Cerrado (Sampaio, 2012; Martins et al., 2012). 
Com frequência as palmeiras se destacam na vegetação nativa brasileira por sua beleza e exuberância, sendo assim muito exploradas para fins ornamentais e paisagísticos (Lorenzi, 2010). Contudo, no Brasil, poucos são os gêneros de palmeiras explorados com fins ornamentais; das cinco subfamílias de Arecaceae, apenas duas (Coryphoideae Burnett e Arecoideae Burnett) são intensamente utilizadas na ornamentação e paisagismo urbano e residencial (Lorenzi \& Souza, 2010), sendo os gêneros Phoenix L. e Chamaedorea Willd. os mais utilizados para esse quesito.

A tribo Cocoseae Mart. é uma das que possui maior importância dentro das Arecaceae, e dentro desta tribo, a subtribo Attaleineae Drude é a que mais se destaca por englobar gêneros com importância ornamental, econômica, medicinal, alimentícia, madeireira e industrial, como Allagoptera Nees, Syagrus Mart. e Cocos L. (Dransfield et al., 2008).

As espécies do gênero Allagoptera apresentam grande valor ornamental e alimentício (Lorenzi \& Souza, 2010). Algumas espécies podem ainda ser exploradas para fins medicinais, artesanais e industriais (Moraes, 1996). Dessa maneira, embora as espécies que compõem o gênero sejam pouco numerosas, estas possuem importância econômica nas regiões onde ocorrem.

Nas Restingas de Marambaia, Rio de Janeiro, Allagoptera arenaria (Gomes) Kuntze se destaca como sendo a espécie com o maior número de indivíduos (Afonso et al., 2007), tornando a paisagem homogênea devido à sua importância fitossociológica na área (Menezes \& Araújo, 2000). A espécie possui bom potencial ornamental, produz frutos comestíveis e suas folhas podem ser utilizadas para a confecção de cestos e obras trançadas (Lorenzi, 2010).

Allagoptera brevicalyx M. Moraes é uma espécie endêmica à vegetação xeromórfica das dunas arenosas litorâneas e pequenos trechos de Cerrado do nordeste do estado da Bahia (Moraes, 1993). Lorenzi (2010) alerta que, por ocorrer em locais tão específicos, a espécie encontra-se ameaçada devido à especulação imobiliária na região. Este mesmo autor aponta que a espécie possui bom potencial ornamental e paisagístico, além de produzir frutos comestíveis. A espécie possui ainda um bom potencial para a extração de cera (Moraes, 1996).

Allagoptera campestris (Mart.) Kuntze produz frutos comestíveis, consumidos in natura pela fauna regional (Martins, 2012), além de apresentar bom potencial na ornamentação. A espécie fornece também importante matéria-prima para a produção de vassouras e produz um suco utilizado para o tratamento de infeç̧ões oftalmológicas (Plotkin \& Balick, 1984). A espécie apresenta ainda o segundo maior valor de importância fitossociológica em área de Cerrado do Parque Nacional da Serra do Cipó, Minas Gerais (Neto \& Júnior, 2002).

Dada a redução das populações de Euterpe edulis Mart. nos últimos anos, a espécie Allagoptera caudescens (Mart.) Kuntze tem sido amplamente utilizada na alimentação, devido ao seu palmito muito consumido e apreciado pelo homem (Rolim et al., 2006). A espécie pode ainda ter usos na ornamentação e no paisagismo (Lorenzi, 2010). 
De acordo com Martins (2012), Allagoptera leucocalyx (Drude) Kuntze possui potencial ornamental e produz frutos que servem como fonte de alimento para a fauna, sendo o mesocarpo e as sementes partes comestíveis. Essa mesma autora aponta que a partir das folhas dessa espécie, é possível confeccionar vassouras e outros objetos artesanais. A espécie também possui aplicações medicinais, sendo utilizada pela tribo Kalunga ao norte do estado de Goiás para o tratamento de problemas digestivos (Martins et al., 2014).

Allagoptera robusta R. C. Martins \& Filg. produz frutos com polpa e sementes comestíveis. A espécie possui ainda bom potencial ornamental, sendo selecionada para a conservação em áreas onde se faz retirada da vegetação (Martins et al., 2015).

\section{Morfologia de Allagoptera Nees}

A descrição morfológica a seguir teve como base os trabalhos de Moraes (1996), Lorenzi (2010) e Martins (2012).

Plantas de 0,3 a 2,0 m de altura, monoicas e acaules, ou curto-caulescentes (exceção Allagoptera caudescens, de até $10 \mathrm{~m}$ de altura); estipe subterrâneo ou muito curto, solitário ou cespitoso; número de folhas variável entre espécies e por vezes até entre espécimes; folhas pinadas, dispostas de maneira espiralada nas plantas; bainha foliar persistente e tubular; pecíolo glabro, coberto por fibras ou por um indumento lanoso na face abaxial; raque foliar glabra ou lanoso-cerosa na face abaxial; segmentos foliares discolores e linear-lanceolados, cobertos ou não por uma ramenta, em grupos inseridos irregularmente em diferentes planos na raque (exceção $A$. caudescens, segmentos foliares regularmente inseridos no mesmo plano na raque); nervura principal em geral proeminente na face adaxial e deprimida abaxialmente; bráctea peduncular lenhosa e persistente; inflorescência interfoliar, não ramificada e espiciforme; flores dispostas de forma congesta em tríades; flores estaminadas sésseis ou curto-pediceladas, trímeras e assimétricas, restritas ao terço superior da inflorescência; sépalas conadas na base; pétalas livres e irregulares; número de estames variável entre espécies e por vezes também entre espécimes; flores pistiladas sésseis, trímeras e globosas, restritas à metade basal da inflorescência; sépalas livres, com superfície lisa ou rugosa; pistilo sincárpico e cônico; óvulos basais, hemianátropos; gineceu oval ou oboval; frutos de coloração amarelo-esverdeada e formato oval, oboval a elipsoide; mesocarpo fibroso e suculento, de coloração amarelo-alaranjada; endocarpo rígido e ósseo; micrópila lateral; endosperma homogêneo; uma única semente por fruto, em geral. 


\section{Anatomia de Arecaceae}

A maior parte da informação utilizada na identificação de plantas é obtida a partir de caracteres morfológicos (Judd et al., 2009). No entanto, embora a maioria dos pesquisadores busquem tais características para a construção de chaves de identificação, nem todas as espécies podem ser diferenciadas morfologicamente, sendo então necessário agregar caracteres anatômicos, ontogenéticos, fisiológicos, embriológicos, cromossômicos, palinológicos ou ecológicos para subsidiar a distinção entre espécies (Herr, 1984; Keating, 1984; Sanders, 1987; Blackmore et al., 1995).

A anatomia tem servido como importante ferramenta à taxonomia de diferentes grupos de plantas (Craene, 2002; Ma \& Saunders, 2003; Gomes et al., 2005), auxiliando na identificação de espécies cujas características morfológicas se confundem. Mesmo quando os caracteres morfológicos são suficientes para a distinção das espécies, as características anatômicas enriquecem a taxonomia, tornando os dados mais consistentes. Tendo em vista a dificuldade de identificação com base em dados morfológicos, estudos anatômicos sobre espécies de Arecaceae têm se apresentado como alternativa interessante para melhor compreensão da taxonomia do grupo (Barfod, 1988; Rudall et al., 2003; Tomlinson et al., 2011).

A partir do trabalho clássico de Tomlinson (1961), uma série de estudos acerca da anatomia das palmeiras foi sendo desenvolvida (Glassman, 1972; Barfod, 1988; Mathew \& Bhat, 1997; Rudall et al., 2003). Sua mais nova versão (Tomlinson et al., 2011) reúne dados de diversos estudos já publicados sobre o tema, tais como Seubert (1996a,b, 1997, 1998a,b), Dransfield et al. (2008) e Horn et al. (2009), facilitando o acesso às informações sobre este grupo de plantas.

Apesar dos estudos que tratam da anatomia radicular (Seubert, 1998a,b) e foliar (Alvarado \& Jáuregui, 2011) de Arecoideae, esta subfamília ainda carece de informações para que relações filogenéticas e de parentesco sejam traçadas (Tomlinson et al., 2011). Attaleinae, uma das principais subtribos de Arecoideae, é caracterizada por uma lâmina espessa, com mesofilo e hipoderme bem desenvolvidos e epiderme com parede externa espessada, principalmente na face adaxial (Tomlinson et al., 2011). Os autores destacam que há uma grande necessidade de que mais estudos anatômicos sejam realizados com os diferentes gêneros dessa importante subtribo.

Para o gênero Allagoptera (Arecoideae, Attaleinae), os estudos são ainda muito escassos. Um trabalho mais geral é apresentado por Moraes (1996), abordando uma revisão taxonômica do gênero e fornecendo contribuições anatômico-foliares, morfológicas, palinológicas e citológicas, dentre outras. Devido à grande abrangência e profundidade do trabalho, as descrições são muito suscintas na parte de anatomia foliar e não foram efetuados cortes paradérmicos das espécies. A autora também faz uma análise apenas da região da lâmina foliar, não analisando caracteres relevantes da margem e do feixe 
vascular principal. O trabalho também não traz micrografias, mas sim desenhos esquemáticos, abordando as quatro espécies que compunham o gênero na época em que foi desenvolvido. Além disso, Moraes afirma que Allagoptera possui células com taninos abundantes, porém não faz uso de nenhuma análise histoquímica em seu trabalho para embasar essa constatação.

Os demais trabalhos que contemplam a anatomia do gênero são focados em anatomia da raiz (Seubert, 1998a,b) e desenvolvimento dos estames (Uhl \& Moore, 1980). Um importante trabalho analisou três espécies do gênero que ocorrem no Cerrado - Allagoptera campestris, A. leucocalyx e $A$. robusta -, comparando-as em aspectos morfoanatômicos (Martins et al., 2015). No entanto, o uso desses caracteres não foi capaz de revelar diferenças significativas entre estas três espécies. A biometria de duas espécies de Allagoptera que ocorrem no Distrito Federal (A. campestris e A. robusta) também não obteve resultados significativos para sua distinção (Martins, 2012). Dessa forma, com base na análise da literatura, podemos ver que caracteres anatômicos parecem ser mais promissores que dados morfológicos para a taxonomia de Allagoptera e, possivelmente, da família Arecaceae como um todo.

\section{Revisão bibliográfica}

Um breve resumo do que é apresentado na literatura científica sobre as diferentes categorias taxonômicas de Allagoptera é apresentada abaixo.

\section{§ Arecoideae Burnett}

Arecoideae não apresenta muitos caracteres anatômicos que permitam a distinção do grupo, o que implica em sinapomorfias ainda não identificadas para a subfamília (Tomlinson et al., 2011). Contudo, podemos diferenciar dois caracteres que parecem estar restritos a Arecoideae: a) os elementos de tubo crivado dos pecíolos e caules são geralmente orientados transversalmente e possuem placas crivadas compostas com um arranjo estrelado de áreas crivadas cuneiformes; b) presença de um tipo de feixe vascular distinto, observado na posição mediana-abaxial dos pecíolos de muitos taxa (Tomlinson et al., 2011). Caracteres da anatomia da lâmina foliar potencialmente distintivos para a subtribo, no entanto, ainda não foram identificados. 


\section{$\S$ Cocoseae Mart.}

Tomlinson (1961) apontou o seguinte conjunto de caracteres anatômicos para a tribo Cocoseae:

a) epiderme com paredes geralmente não sinuosas;

b) tricomas dispersos em ambas as superfícies epidérmicas, ou ausentes;

c) células-guarda com duas saliências externas cutinizadas e proeminentes, podendo às vezes apresentar duas saliências internas menos proeminentes;

d) hipoderme bem desenvolvida, geralmente 1-2 camadas abaixo de cada superfície epidérmica;

e) mesofilo isobilateral ou dorsiventral;

f) fibras abundantes, em agrupamentos regulares ou irregulares na hipoderme adaxial;

g) feixes vasculares situados mais abaxialmente no mesofilo, em contato com a epiderme ou hipoderme abaxial;

h) células de expansão (= células buliformes) geralmente em bandas abaxiais conspícuas, ocupando quase toda a espessura da lâmina.

\section{§ Attaleinae Drude}

Tomlinson et al. (2011) descreveram como caracteres anatômicos diagnósticos para a subtribo Attaleinae:
a) lâmina espessa, mesofilo com muitas camadas de células;
b) epiderme com parede externa espessada;
c) tricomas com uma ou poucas células basais;
d) hipoderme bem desenvolvida;
e) mesofilo isobilateral ou dorsiventral, com camada de células paliçádicas bem desenvolvida;
f) fibras contíguas a hipoderme;
g) feixes vasculares longitudinais em contato com uma ou ambas as faces epidérmicas;
h) feixes transversais amplos, com bainha fibrosa bem desenvolvida;
i) células silicosas (estegmata) com corpos silicosos esféricos;
j) feixes vasculares do pecíolo com um vaso de metaxilema e dois crivos de floema. 


\section{§ Allagoptera Nees}

Moraes (1996) descreveu como caracteres anatômicos diagnósticos para o gênero Allagoptera:
a) epiderme uniestratificada, com parede externa espessada - principalmente na face adaxial;
b) cutícula fina;
c) estômatos restritos às regiões intercostais da superfície abaxial;
d) hipoderme com 3-4 camadas adaxialmente e 1-2 camadas abaxialmente;
e) mesofilo dorsiventral;
f) células com taninos abundantes;
g) feixes mais proeminentes abaxialmente;
h) distância entre os feixes vasculares variável entre as espécies.

\section{Fórmula Vascular}

No trabalho clássico de Türpe (1967) com espécies argentinas do gênero de gramíneas Paspalum L. (Poaceae), a autora foi capaz de elaborar uma forma bastante eficaz para diferenciar os feixes vasculares maiores dos menores, classificando-os em feixes de primeira, segunda e terceira ordem, de acordo com seu calibre. Além disso, o trabalho traz a distinção dos feixes vasculares em travados (extensões de bainha de feixe ligadas à hipoderme), semi-travados (uma fileira de células entre as extensões de bainhas de feixe e a hipoderme) e livres (extensões de bainhas de feixe não ligadas à hipoderme), sintetizando assim o modo de descrever a anatomia das espécies.

Com base nos conceitos apresentados por Türpe (1967), foi constatado que os gêneros Paspalum e Arundo L. apresentam um padrão vascular que se repete ao longo das alas da lâmina foliar (Silva, 2012). Aliado a outras características anatômicas dos feixes vasculares, foi sugerida uma fórmula vascular, uma nova proposta baseada no padrão vascular das espécies de gramíneas e que se mostrou bastante útil para a sua distinção (Silva, 2012).

Embora aplicável primeiramente às gramíneas, a fórmula vascular parece ser aplicável também a outros grupos com nervuras paralelódromas, tendo se mostrado aplicável à espécie de Arecaceae Syagrus glazioviana (Dammer) Becc (Gomes \& Borges, 2013). Se aplicável ao gênero Allagoptera, a fórmula vascular pode ser de grande auxílio à taxonomia, reunindo de maneira simplificada dados e informações anatômicas de espécies, e até mesmo de gêneros, e facilitando a comparação entre os grupos (Silva, 2012). 


\section{$\mathbf{H}_{\text {ipotseses }}$}

- Existem caracteres anatômicos foliares no gênero Allagoptera que podem subsidiar a taxonomia no gênero.

- As células de Allagoptera são abundantes em compostos fenólicos, principalmente taninos (hipótese baseada em Moraes, 1996).

- Allagoptera apresenta padrão vascular, que pode ser representado em uma fórmula vascular.

\section{Objetivo geral}

- Analisar a anatomia foliar das espécies de Allagoptera Nees (Arecaceae).

\section{Objetivos específicos}

- Descrever a anatomia foliar das espécies de Allagoptera.

- Identificar caracteres anatômicos da folha de Allagoptera, inclusive da epiderme, que possam ser utilizados na taxonomia do gênero.

- Identificar a presença de possíveis compostos fenólicos (especificamente taninos) nas folhas de Allagoptera.

- Verificar se existe um padrão vascular nas folhas de Allagoptera e se o mesmo pode ser representado em uma fórmula vascular. 


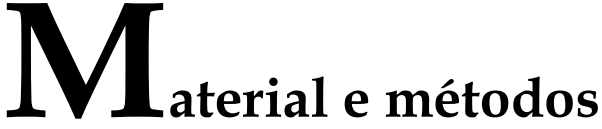

\section{Coleta do material}

Expedições foram realizadas a diferentes localidades do Brasil de modo a coletar as espécies do gênero Allagoptera. O material foi coletado em diferentes localidades do Distrito Federal, Goiás e Rio de Janeiro, além de ter sido obtido empréstimo de material de herbários da Bahia para a espécie Allagoptera brevicalyx. Todas as espécies coletadas encontram-se depositadas no herbário da Universidade de Brasília (UB).

Seguiu-se o roteiro de Martins \& Filgueiras (2010) para a coleta das palmeiras, tendo sido coletadas folhas e inflorescências para a confecção das exsicatas, que foram depositadas no Herbário UB. O gênero Allagoptera foi diferenciado no campo de Syagrus Mart. pela inflorescência espiciforme e pelo tamanho irregular dos frutos (Martins, 2012).

Para os estudos anatômicos, foram coletados segmentos foliares de pelo menos quatro indivíduos, de modo a garantir uma representatividade da espécie. Para cada indivíduo, utilizou-se uma replicata de quatro amostras a execução das análises anatômicas. O material coletado foi fixado ainda no campo em FAA50, permanecendo nesta solução durante dois a sete dias, quando foi então transferido para etanol $70 \%$, conforme o procedimento clássico realizado em anatomia vegetal (Johansen, 1940).

Para Allagoptera brevicalyx, foram retiradas amostras das folhas das exsicatas provenientes de empréstimo do Herbário da Universidade Federal da Bahia, mediante autorização da curadora Nádia Roque (ALCB). As amostras foram reidratadas em solução de água destilada com glicerina por $48 \mathrm{~h}$ na estufa a cerca de $60^{\circ} \mathrm{C}$ e só então conservadas em etanol $70 \%$.

As amostras foram retiradas do terço mediano dos segmentos foliares, situados na região mediana da folha, tanto para os materiais provenientes de coletas próprias quanto para os oriundos de exsicatas de herbários. A Tabela 1 apresenta os locais de coleta das espécies e seus respectivos vouchers nos herbários. 
Tabela 1. Vouchers das espécies de Allagoptera Nees (Arecaceae) analisadas quanto a sua anatomia foliar. $\left({ }^{*}\right)$ Espécie analisada exclusivamente a partir de material herborizado. ALCB - Herbário Alexandre Leal Costa; HUEFS - Herbário da Universidade Estadual de Feira de Santana; UB - Herbário da Universidade de Brasília.

\begin{tabular}{|c|c|c|}
\hline Espécie & Voucher & Locais de coleta \\
\hline Allagoptera arenaria & Pinedo, A. S. & Reserva Biológica de Jurubatiba - RJ \\
\hline (Gomes) Kuntze & UB $(8,9,10)$ & $22^{\circ} 14^{\prime} \mathrm{S} 41^{\circ} 35^{\prime} \mathrm{W}$ (Restinga) \\
\hline Allagoptera brevicalyx & Guedes, M. L. et al. & Área de preservação UNIDUNAS - BA \\
\hline \multirow[t]{7}{*}{ M. Moraes $\left({ }^{*}\right)$} & ALCB (19334) & $12^{\circ} 14^{\prime} \mathrm{S} 37^{\circ} 51^{\prime} \mathrm{W}$ (Restinga) \\
\hline & Loureiro, D. M. et al. & Mata de São João - BA \\
\hline & ALCB (755) & $12^{\circ} 32^{\prime} \mathrm{S} 38^{\circ} 17^{\prime} \mathrm{W}$ (Restinga) \\
\hline & Guedes, M. L. & Dunas do aeroporto de Salvador-BA \\
\hline & ALCB (1213) & $12^{\circ} 55^{\prime} \mathrm{S} 38^{\circ} 19^{\prime} \mathrm{W}$ (Restinga) \\
\hline & Matos \& Vidal & Mata de São João - BA \\
\hline & HUEFS (797) & $12^{\circ} 32^{\prime} \mathrm{S} 38^{\circ} 17^{\prime} \mathrm{W}$ (Restinga) \\
\hline Allagoptera campestris & Pinedo, A. S. & Jardim Botânico de Brasília - DF \\
\hline (Mart.) Kuntze & UB $(2,4)$ & $15^{\circ} 52^{\prime} \mathrm{S} 47^{\circ} 50^{\prime} \mathrm{W}$ (Campo sujo, Cerrado) \\
\hline Allagoptera caudescens & Pinedo, A. S. & Reserva Ecológica Poço das Antas - RJ \\
\hline (Mart.) Kuntze & UB $(6,7)$ & $22^{\circ} 35^{\prime} \mathrm{S} 42^{\circ} 20^{\prime} \mathrm{W}$ (Mata Atlântica) \\
\hline Allagoptera leucocalyx & Pinedo, A. S. \& Silvestre, L. F. F. & Córrego Quebra Coco, Cavalcante - GO \\
\hline (Drude) Kuntze & UB $(11,12)$ & $13^{\circ} 36^{\prime} \mathrm{S} 47^{\circ} 28^{\prime} \mathrm{W}$ (Cerradão, Cerrado) \\
\hline Allagoptera robusta & Pinedo, A. S. \& Martins, R. C. & Setor de Mansões Park Way - DF \\
\hline R. C. Martins \& Filg. & UB $(1,3)$ & $15^{\circ} 53^{\prime} \mathrm{S} 47^{\circ} 55^{\prime} \mathrm{W}$ (Cerradão, Cerrado) \\
\hline
\end{tabular}




\section{Estudos anatômicos}

\section{Secções transversais}

Tanto para os espécimes coletados quanto para os recebidos de herbários, amostras de aproximadamente $2 \mathrm{~cm}^{2}$ do terço médio do segmento foliar foram reidratadas e seccionadas transversalmente em micrótomo de mesa do tipo Ranvier. Foi utilizado isopor como suporte para a obtenção dos cortes.

As seç̧̃̃es foliares obtidas foram colocadas em placa de petri com água e clarificadas com hipoclorito de sódio $2,5 \%$. Os cortes foram lavados cinco vezes com água destilada e receberam dupla coloração alcoólica com azul de Alcian e safranina 4:1 por cerca de 5 min. Utilizou-se etanol 50\%, etanol comercial $(92,8 \%)$ e etanol absoluto $(99,2 \%)$ para retirar o excesso de corante dos cortes. Feito isso, as secções seguiram para a montagem das lâminas.

A montagem das lâminas foi realizada em gelatina glicerinada, que foi aquecida e colocada na lâmina, em cima da qual foram organizadas cinco a oito secções foliares. Cada lâmina foi então coberta por uma lamínula e, havendo necessidade, realizou-se um rápido aquecimento da lâmina na lamparina para evitar bolhas e acomodar melhor a gelatina. O bordo das lâminas semi-permanentes foi fechado com esmalte incolor (marca Colorama).

A análise histoquímica foi realizada para localização de compostos fenólicos e de taninos nos tecidos. Secções transversais foliares foram submetidas ao cloreto férrico aquoso $10 \%$, por 2 min, que resulta em coloração preta em presença de compostos fenólicos (Arduin \& Krauss, 1997). Para a deteç̧ão de taninos, utilizou-se tanto vanilina $10 \%$ quanto solução aquosa concentrada de sulfato ferroso a 1\%. Para a vanilina, após 2 min na solução as secções reagiam, resultando em coloração castanho-amarronzada nas regiões onde há presença de taninos. Para o sulfato ferroso, as secções reagiram apenas após 10 min, evidenciando coloração próxima ao azul-escuro nas reações positivas (Arduin \& Krauss, 1997). O controle foi feito com as seç̧ões montadas com solução de glicerina com água destilada na proporção 1:1. Observou-se que a vanilina não foi um reagente eficaz para a análise histoquímica, uma vez que o corante reagiu com os taninos e produz uma coloração marrom acastanhada, tom muito semelhante à das espécies em estudo. Dessa maneira, optou-se pela utilização apenas de sulfato ferroso a $1 \%$ para a detecção de taninos nos segmentos foliares.

As análises anatômicas e histoquímicas foram realizadas em microscópio óptico marca Zeiss e as imagens foram registradas com fotomicroscópio marca Leika associado ao microcomputador com sistema de captura de imagens LAS EZ. 


\section{Cortes paradérmicos}

Para a obtenção dos cortes paradérmicos, amostras foliares com cerca de $1 \mathrm{~cm}^{2}$ foram colocadas em vidros de penicilina contendo solução de Franklin 30\% (Johansen, 1940), de modo que o material ficasse totalmente imerso na solução. Os vidros contendo as amostras foram então colocados em estufa a $60^{\circ} \mathrm{C}$ por dois a cinco dias, ou até a epiderme se dissociar, o que normalmente ocorreu quando havia perda de coloração da estrutura e esta ficava transparente. A solução de Franklin foi então descartada e as amostras foram lavadas em água destilada cinco vezes para a retirada do excesso da solução.

Com o auxílio de pincéis, os resquícios de mesofilo foram removidos, isolando assim os cortes paradérmicos. As amostras passaram pelo corante safranina por um minuto e então foram lavadas três vezes para a retirada do excesso de corante. Em seguida, foram colocadas na lâmina, sendo cobertas com gelatina e lamínula, selada com esmalte incolor. O registro das imagens foi realizado em fotomicroscópio associado ao microcomputador com sistema de captura de imagens LAS EZ.

A Fig. 1 esquematiza todo o procedimento realizado para o estudo anatômico. Foram analisados ao menos quatro indivíduos por espécie. As amostras retiradas do terço médio do segmento foliar mediano foram cortadas em pequenas seç̧ões de aproximadamente $1 \mathrm{~cm}^{2}$ para a realização dos cortes paradérmicos e de aproximadamente $2 \mathrm{~cm}^{2}$ para a obtenção das seç̧ões transversais. Para cada indivíduo, utilizou-se uma replicata de quatro amostras para efetuar as análises anatômicas e compilar os dados para a obtenção da fórmula vascular.

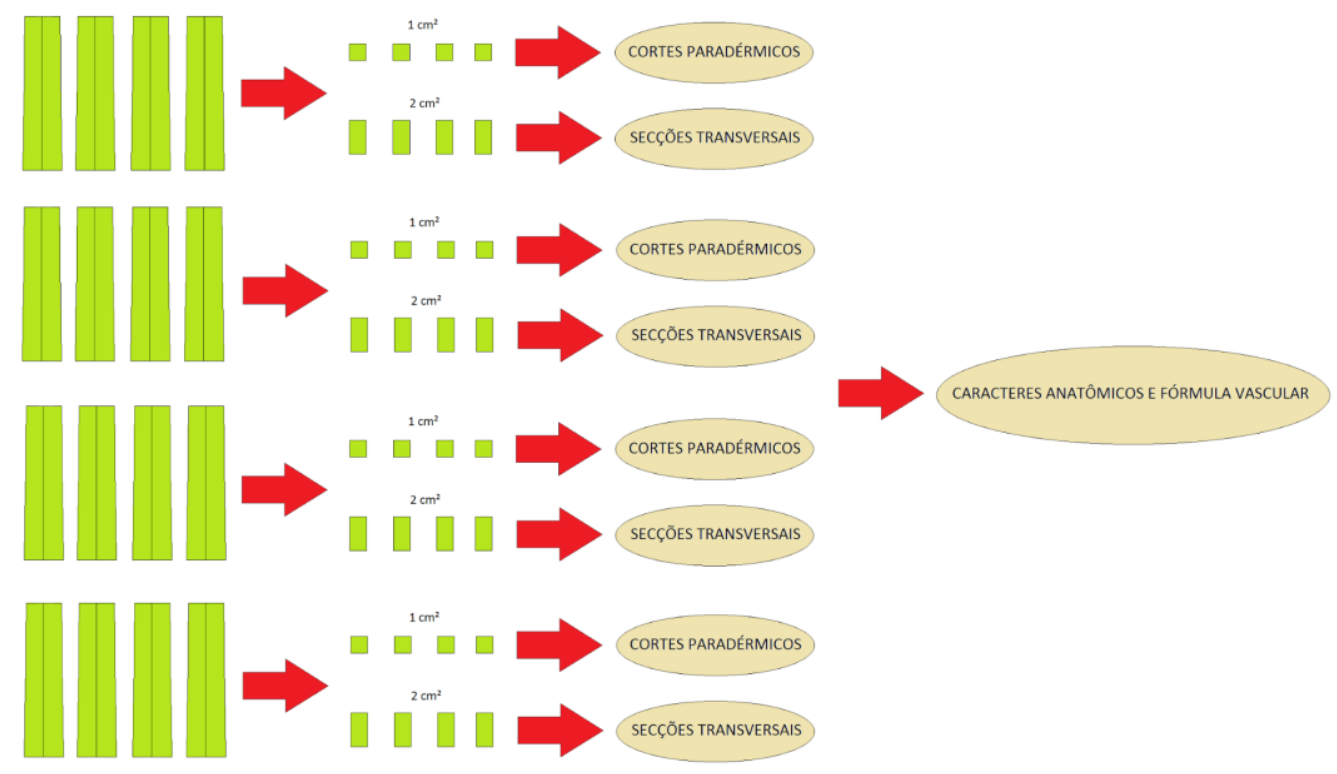

Fig. 1. Exemplo da metodologia realizada para os estudos anatômicos em uma espécie. 


\section{Análise dos dados e terminologias}

Foram compilados os caracteres anatômicos foliares usados por diferentes autores que analisaram espécies de Arecaceae (ver Tabela 4 em anexo). À medida que as lâminas foram analisadas, selecionaram-se os caracteres aplicáveis às espécies de Allagoptera, a fim de compor as descrições. As regiões da epiderme e as células comuns, o complexo estomático, as células-guarda e as células subsidiárias foram analisadas por meio dos cortes paradérmicos, com exceção dos caracteres formato e relação altura versus largura das células comuns, formato e posição das células-guarda e formato das células subsidiárias, que foram analisados em secção transversal.

As análises quantitativas foram realizadas tomando-se pelo menos quatro vezes as medidas de dois segmentos foliares de três indivíduos da mesma espécie e calculando-se a média.

A terminologia "células buliformes" (Appezzato-da-Glória \& Carmello-Guerreiro, 2009), adotada para gramíneas, foi adotada em detrimento de "tecido de expansão" (Silva \& Potiguara, 2008; Sanín \& Galeano, 2011; Martins, 2012), "células de expansão" (Millán \& Kahn, 2010; Alvarado \& Jáuregui, 2011; Tomlinson et al., 2011), ou “tecido de expansão celular" (Glassman, 1972; Noblick, 2013).

A terminologia "feixe(s)" foi reservada apenas para feixes vasculares, sendo esta denominação substituída para "grupo(s)" quando se refere a fibras (grupos de fibras). A terminologia "segmentos foliares" foi adotada em lugar de "pinas" para designar cada uma das estruturas fotossintetizantes que compõem a folha pinada. Foram adotadas as terminologias de Türpe (1967) para denominação dos feixes vasculares em travados, semi-travados ou livres. Foram considerados travados os feixes em contato direto com a hipoderme, semi-travados os feixes ligados à hipoderme por uma camada de células e livres os feixes não ligados à hipoderme (Türpe, 1967). Adotou-se adicionalmente a denominação de feixes vasculares de quarta ordem para designar todos os feixes de menor calibre.

As margens foliares foram classificadas como arredondadas ou inclinadas, de acordo com sua morfologia (Fig. 2).

As descrições anatômicas seguiram o padrão geral usado em Taxonomia Vegetal, sem verbos, e com base nos seguintes critérios: a) os caracteres anatômicos em comum entre as espécies constaram apenas na descrição do gênero, não sendo incluídos na descrição das espécies; b) a faixa de variação dos caracteres entre as espécies foi apontada na descrição do gênero (por exemplo, mesofilo dorsiventral a homogêneo); c) caracteres anatômicos que se mostraram divergentes entre duas espécies ou mais foram incluídos na descrição de cada uma das espécies. 


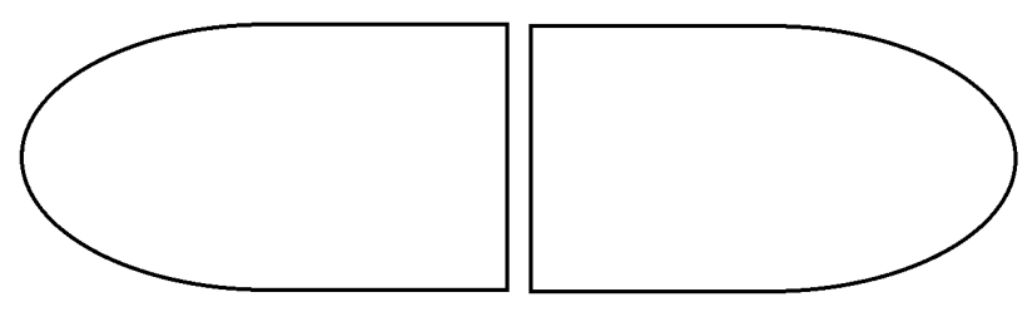

MARGEM ARREDONDADA

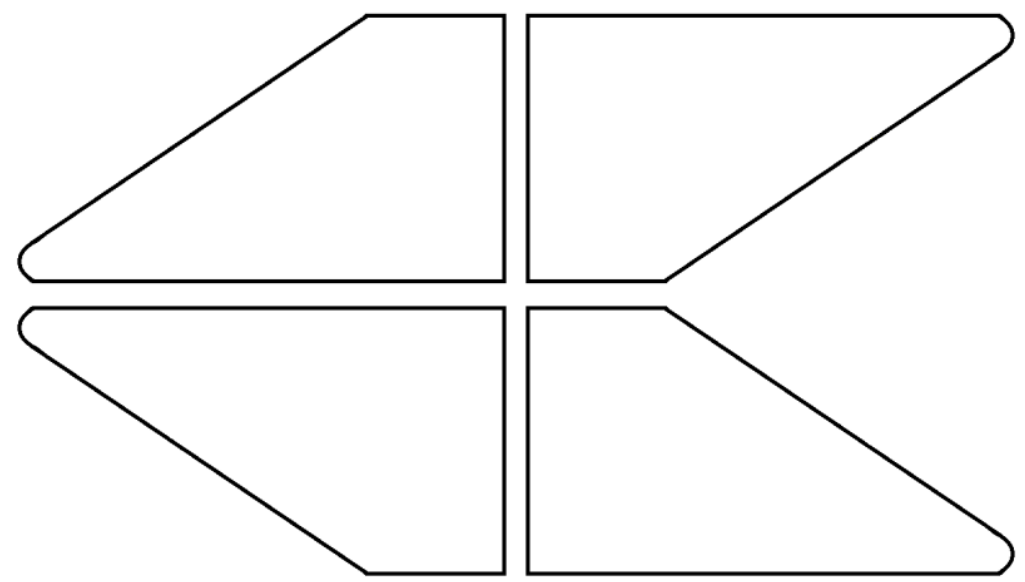

MARGEM INCLINADA

Fig. 2. Esquema ilustrando as diferenças morfológicas entre as margens foliares. Cada par representa as margens de um mesmo segmento foliar.

\section{Fórmula e Esquema Vascular}

A fórmula vascular (FV), proposta por Silva (2012) para espécies de Paspalum (Poaceae), foi testada para as espécies de Allagoptera estudadas neste trabalho. Para isso, as secções anatômicas foliares obtidas a partir de diferentes indivíduos, foram analisadas, com a finalidade de verificar a existência de um padrão vascular. Em caso afirmativo, foi aplicada a FV para a descrição deste padrão, bem como de outras caraterísticas anatômicas foliares. Os dados obtidos para determinar a FV de cada espécie foram obtidos por meio de uma média aritmética simples feita com duas amostras de quatro indivíduos da mesma espécie. Os símbolos e letras utilizados na FV encontram-se na Tabela 2. Foram realizadas alterações na tabela original de Silva (2012), a fim de incluir feixes de quarta ordem e separar o mesofilo dorsiventral clássico do dorsiventral gradativo. É também proposto aqui um Esquema Vascular (EV), que segue o mesmo princípio da Fórmula Vascular (FV) proposta por Silva (2012), porém faz o uso de outra simbologia para esquematizar o padrão vascular. Esta simbologia é apresentada na Tabela 3. 
Tabela 2. Símbolos e letras utilizados na Fórmula Vascular (FV) e seus respectivos significados (adaptado de Silva, 2012). Caracteres incluídos no presente trabalho estão indicados com asterisco $(*)$.

\begin{tabular}{|c|c|c|c|}
\hline Símbolo / letra & Significado & Símbolo / letra & Significado \\
\hline $\mathrm{P}$ & feixes vasculares de primeira ordem & $x^{E}$ & bainha esclerenquimática \\
\hline $\mathrm{S}$ & feixes vasculares de segunda ordem & $x^{p}$ & bainha parenquimática \\
\hline $\mathrm{T}$ & feixes vasculares de terceira ordem & $\bar{X}$ & feixe semi-travado adaxialmente \\
\hline$Q^{*}$ & feixes vasculares de quarta ordem* & $\overline{\bar{X}}$ & feixe travado adaxialmente \\
\hline ( ) & bainha completa (ausência significa bainha incompleta) & $\underline{X}$ & feixe semi-travado abaxialmente \\
\hline [ ] & isola um grupo de feixes com as mesmas características & $\underline{\underline{X}}$ & feixe travado abaxialmente \\
\hline\{\} & isolamento de grupos de feixes com características semelhantes & $\underline{\overline{\bar{X}}}$ & feixe travado adaxial e abaxialmente \\
\hline+ & une duas representações diferentes da mesma área & $\underline{\bar{X}}$ & feixe semi-travado adaxial e abaxialmente \\
\hline$\left.\right|^{*} \mid$ & clorênquima radial & $x$ & feixe livre adaxial e abaxialmente \\
\hline$\|\left.\right|^{*}$ & mesofilo homogêneo* & $X_{\text {subscrito }}$ & número de feixes entre um feixe de uma ordem e outro \\
\hline$|-|$ & mesofilo isolateral & $\approx$ & total aproximado de feixes entre uma margem e outra \\
\hline$|\mathrm{T}|$ & mesofilo dorsiventral clássico & $\geq$ & $\begin{array}{l}\text { número proximal / medial ou maior do total dos feixes entre } \\
\text { uma margem e outra }\end{array}$ \\
\hline$|J|^{*}$ & mesofilo dorsiventral gradativo* & $\infty$ & incontáveis ou inúmeros feixes entre uma margem e outra \\
\hline
\end{tabular}


Tabela 3. Lista de símbolos utilizados no Esquema Vascular (EV) e seus respectivos significados.

\begin{tabular}{|c|c|c|}
\hline & feixe vascular de primeira ordem & feixe travado/semi-travado adaxial e abaxialmente \\
\hline & feixe vascular de segunda ordem & feixe travado adaxialmente e travado/semi-travado abaxialmente \\
\hline & feixe vascular de terceira ordem & feixe travado/semi-travado adaxialmente e travado abaxialmente \\
\hline $\mathbf{I}$ & feixe vascular de quarta ordem & feixe travado/semi-travado adaxialmente e travado/livre abaxialmente \\
\hline & mesofilo isobilateral & feixe travado/livre adaxialmente e travado/semi-travado abaxialmente \\
\hline & mesofilo dorsiventral clássico (ausência = homogêneo) & feixe travado/livre adaxial e abaxialmente \\
\hline - & mesofilo dorsiventral gradativo & feixe semi-travado adaxialmente e livre abaxialmente \\
\hline ! & feixe livre adaxial e abaxialmente & feixe semi-travado/livre adaxialmente e livre abaxialmente \\
\hline$\underline{I}$ & feixe semi-travado adaxial e abaxialmente & feixe travado adaxialmente e livre abaxialmente \\
\hline I & feixe semi-travado adaxilamente e semi-travado/livre abaxialmente & feixe travado/semi-travado adaxialmente e livre abaxialmente \\
\hline$\underline{1}$ & feixe semi-travado/livre adaxialmente e semi-travado abaxialmente & feixe travado/livre adaxialmente e livre abaxialmente \\
\hline I & feixe semi-travado/livre adaxial e abaxialmente & feixe livre adaxialmente e semi-travado abaxialmente \\
\hline$\underline{\underline{I}}$ & feixe travado adaxial e abaxialmente & feixe livre adaxialmente e semi-travado/livre abaxialmente \\
\hline
\end{tabular}




\section{continuação.}

\begin{tabular}{|c|c|c|c|}
\hline$\underline{!}$ & feixe livre adaxialmente e travado abaxialmente & $\prod_{= \pm}$ & feixe semi-travado adaxialmente e travado/livre abaxialmente \\
\hline$\frac{1}{x}$ & feixe livre adaxialmente e travado/semi-travado abaxialmente & $\underline{\underline{I}}$ & feixe semi-travado/livre adaxialmente e travado abaxialmente \\
\hline$\left.\right|_{: z}$ & feixe livre adaxialmente e travado/livre abaxialmente & $\underline{I}$ & feixe semi-travado/livre adaxialmente e travado/semi-travado abaxialmente \\
\hline$\overline{\bar{l}}$ & feixe travado adaxialmente e semi-travado abaxialmente & $\mid$ & feixe semi-travado/livre adaxialmente e travado/livre abaxialmente \\
\hline$=$ & feixe travado/semi-travado adaxialmente e semi-travado abaxialmente & & feixe vascular principal* \\
\hline I & feixe travado/livre adaxialmente e semi-travado abaxialmente & | & bainha parenquimática \\
\hline & feixe travado adaxialmente e semi-travado/livre abaxialmente & $\|$ & bainha esclerenquimática \\
\hline & $\begin{array}{l}\text { feixe travado/semi-travado adaxialmente e semi-travado/livre } \\
\text { abaxialmente }\end{array}$ & $\approx$ & número proximal / medial do total de feixes na lâmina foliar \\
\hline î & feixe travado/livre adaxialmente e semi-travado/livre abaxialmente & $\geq$ & número proximal / medial ou maior do total dos feixes na lâmina foliar \\
\hline$\underline{I}$ & feixe semi-travado adaxialmente e travado abaxialmente & $\infty$ & incontáveis ou inúmeros feixes na lâmina foliar \\
\hline$\underline{\mathrm{I}}$ & feixe semi-travado adaxialmente e travado/semi-travado abaxialmente & + & indica a existência de mais de um EV, que será indicado a seguir \\
\hline
\end{tabular}

*o feixe vascular principal também é classificado em travado, semi-travado e livre, com as mesmas notações dos feixes vasculares de diferentes ordens de grandeza. 


\section{$\mathbf{R}_{\text {suluados }}$}

\section{Adequação metodológica}

Ao longo da realização deste trabalho, constatou-se que os segmentos foliares eram demasiado largos, o que impossibilitou a utilização do caule de medula de embaúba como suporte para obtenção dos cortes em micrótomo de mesa. Dessa maneira, embora o isopor seja uma técnica menos prática, optou-se por sua utilização, visto que este material pôde abarcar toda a extensão foliar das amostras.

Para as espécies analisadas, as secções transversais obtidas, ainda que estivessem bem finas, demandaram muito tempo para clarificar. Por isso, a clarificação foi uma etapa que demandou mais tempo do que as outras (cerca de duas horas no total), e a concentração de hipoclorito utilizada foi maior (de $1,25 \%$ a $2,5 \%$ ).

O verniz vitral funcionou bem como meio de montagem para algumas espécies, mas não tão bem para outras - Allagoptera arenaria, A. leucocalyx e A. robusta-, que engruvinharam ao entrar em contato com este reagente. Optou-se, portanto pela padronização da montagem das lâminas em gelatina de modo a evitar o enrugamento das amostras, obtendo-se assim lâminas semi-permanentes. 


\section{Descrição anatômica}

\section{Allagoptera Nees}

Lâmina foliar convexa adaxialmente e plana a convexa abaxialmente; epiderme uniestratificada; complexo cutícula-parede periclinal externa da mesma espessura ou mais espesso que o protoplasto (mais delgado em A. campestris); células comuns da epiderme de contorno regular (exceto em $A$. caudescens), formatos variados; tricomas ausentes; papilas globosas em uma ou em ambas as faces foliares; compostos fenólicos abundantes nas células do mesofilo; epiderme na face adaxial 5,9-14,7 $\mu \mathrm{m}$ de espessura, lâmina sem ondulações aparentes, fibras subepidérmicas em uma faixa contínua ou em grupos isolados; epiderme na face abaxial 4,4-14,9 $\mu \mathrm{m}$ de espessura, lâmina reta a acentuadamente sulcada; folhas hipoestomáticas, complexo estomático tetracítico, estômatos dispostos regularmente em fileiras; câmaras subestomáticas ausentes ou presentes ( $A$. robusta); cristas subsidiárias presentes; células-guarda reniformes, em depressões (23,5-40,2 $\mu \mathrm{m}$ de comprimento e 9,9-17,4 $\mu \mathrm{m}$ de largura); células subsidiárias com formatos variáveis; células buliformes restritas à face abaxial, 2-3 camadas de células; mesofilo dorsiventral a homogêneo, 4-8 camadas celulares $(112,4-337,3 \mu \mathrm{m}$ de espessura), grupos de fibras subepidérmicas restritos à face adaxial, células do mesofilo com taninos abundantes (Fig. 9 e Fig. 10); células do parênquima clorofiliano 1-4 vezes mais altas que largas; parênquima lacunoso com mais de 3 camadas celulares; idioblastos ausentes; hipoderme uniestratificada, mais espessa que a epiderme, células adaxiais ligeiramente maiores que abaxiais, ou menores ( $A$. caudescens), circulares, ovoides ou retangulares; hipoderme adaxial 11,3-21,1 $\mu \mathrm{m}$ de espessura; hipoderme abaxial 7,9-21,8 $\mu \mathrm{m}$ de espessura; feixes vasculares em geral de até 4 a ordem, raro até 3a (A. brevicalyx); bainha dos feixes vasculares esclerenquimática; região da nervura principal com células hipodérmicas de formato semelhante às das demais regiões da lâmina; disposição em atactostelo ( $A$. caudescens); feixe vascular principal colateral ou bicolateral, circular ou ovóide; metaxilema ao centro da nervura; floema em grupos com células esclerenquimáticas; feixes vasculares de primeira ordem ovoides, travados ou semi-travados adaxialmente e travados, semi-travados ou livres abaxialmente; feixes vasculares de segunda ordem ovoides, travados, semi-travados ou livres adaxialmente, travados, semi-travados ou livres abaxialmente; feixes vasculares de terceira ordem ovoides, travados ou livres adaxialmente, travados ou semi-travados abaxialmente; feixes vasculares de quarta ordem circulares, livres adaxialmente (travados em $A$. campestris), travados abaxialmente (semi-travados em $A$. leucocalyx); bainha dos feixes vasculares de primeira e segunda ordens completa; bainha dos feixes vasculares de terceira e quarta ordem incompleta (exceto $A$. campestris e $A$. robusta); grupos de fibras adjacentes ou internos à hipoderme (A. caudescens), obtriangulares ou elípticos deitados, número de fibras variável; margem foliar inclinada ou arredondada; fórmula vascular variável entre as espécies. 
Lâmina foliar convexa adaxialmente e plana a côncava abaxialmente, face abaxial com leves depressões (Fig. 3A); epiderme da face adaxial mediana $(9,3 \pm 1,3 \mu \mathrm{m}$ de espessura), mais delgada que a epiderme da face abaxial, fibras subepidérmicas organizadas em uma faixa quase contínua (Fig. 3D); papilas presentes adaxialmente; células comuns da epiderme da face adaxial retangulares a trapezoides, tamanho variável entre si, 2-3 vezes mais largas do que altas (Fig. 3G); epiderme da face abaxial espessa $(12,9 \pm 2,0 \mu \mathrm{m}$ de espessura); células comuns da epiderme da face abaxial retangulares, tamanho variável entre si, 2-3 vezes mais largas do que altas (Fig. 3I); estômatos na região intercostal, em três ou mais fileiras contíguas entre si (Fig. $3 \mathrm{H})$; cristas estomáticas presentes; células-guarda 2-3 vezes mais compridas que largas $(28,5 \pm 3,0 \mu \mathrm{m}$ de comprimento e $13,9 \pm 1,5 \mu \mathrm{m}$ de largura); células subsidiárias em formato de "V"; células buliformes retangulares, em grupos 2 vezes mais largos que altos, 3 camadas celulares (Fig. 3B); mesofilo dorsiventral gradativo, 5-8 camadas de células $(289,3 \pm 28,9 \mu \mathrm{m}$ de espessura) (Fig. 3A); parênquima paliçádico com 2-3 camadas de células, 3-4 vezes mais altas que largas; parênquima lacunoso com células braciformes; hipoderme adaxial espessa $(17,6 \pm 3,5 \mu \mathrm{m}$ de espessura), células ovoides (Fig. 3D); hipoderme abaxial mediana (14,3 $\pm 2,3 \mu \mathrm{m}$ de espessura), células isodiamétricas (Fig. 3E); feixe vascular principal colateral, circular, travado ou semi-travado, tanto adaxial quanto abaxialmente; protoxilema voltado para a face adaxial; um único vaso de metaxilema; floema restrito à região inferior do xilema (Fig. 3B); feixes vasculares de primeira ordem semi-travados, tanto adaxial quanto abaxialmente; feixes vasculares de segunda ordem semi-travados adaxialmente e semi-travados ou livres abaxialmente; feixes vasculares de terceira ordem livres adaxialmente e travados ou semi-travados abaxialmente; feixes vasculares de quarta ordem livres adaxialmente e travados abaxialmente (Fig. 3A); feixes vasculares comissurais localizados adaxialmente na lâmina; grupos de fibras abundantes, formato elíptico deitado a obtriangular, mais de 10 fibras por grupo, adjacentes à hipoderme adaxial em uma faixa quase contínua (Fig. 3A); fibras do mesofilo de formato distinto daquelas da bainha dos feixes vasculares; margem foliar inclinada; grupos de fibras marginais ovoides ou circulares, 1 ou mais (Fig. 3C).

$$
\begin{aligned}
& |\underline{\underline{P}}\{\underline{\underline{Q}} \underline{\underline{T}} \underline{\underline{Q}}\} \underline{\bar{S}}\{\underline{\underline{Q}} \underline{\underline{T}} \underline{\underline{Q}}\} \underline{\bar{P}}|^{\mathrm{E}}|\mathrm{J}| \approx 100
\end{aligned}
$$

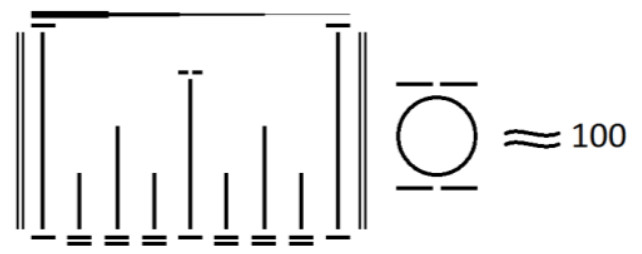



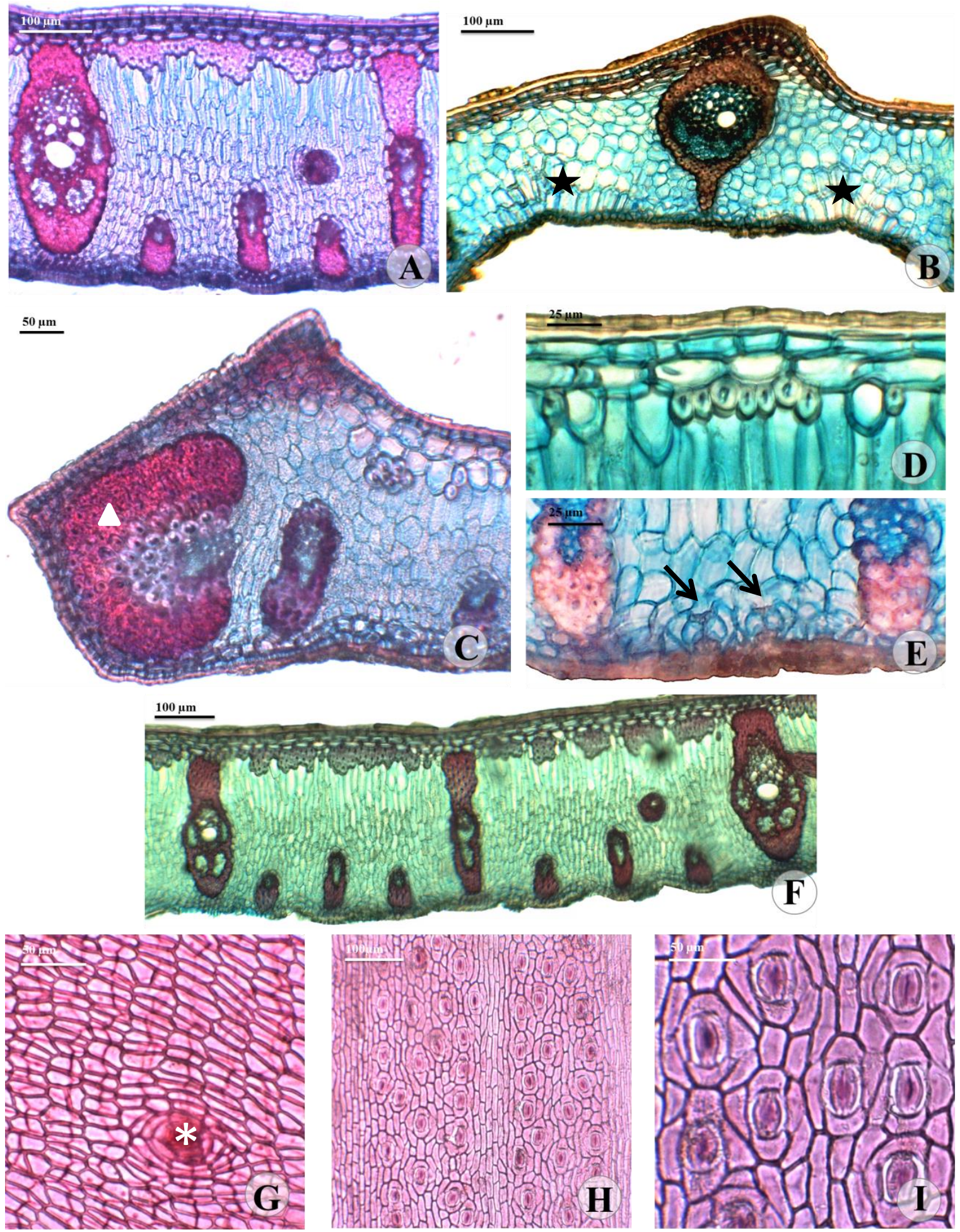

Fig. 3. Anatomia foliar de Allagoptera arenaria (Gomes) Kuntze (Restinga) A-F: Secções transversais; G-I: Cortes paradérmicos. A. Visão geral da lâmina foliar (mesofilo dorsiventral gradativo). B. Feixe vascular principal do segmento, evidenciando as células buliformes (estrelas). C. Margem do segmento foliar com grupo de fibras marginais (triângulo). D. Face adaxial do segmento. E. Face abaxial do segmento com complexo estomático (setas). F. Padrão dos feixes vasculares. G. Epiderme na face adaxial com uma papila (asterisco). H. Epiderme na face abaxial com a disposição dos estômatos. I. Complexo estomático. Escalas: A-C, F, H: $100 \mu \mathrm{m} ; \mathrm{G}, \mathrm{I}: 50 \mu \mathrm{m}$; D-E: $25 \mu \mathrm{m}$. 
Lâmina foliar convexa adaxialmente e plana abaxialmente, face abaxial levemente sulcada (Fig. $4 \mathrm{~A})$; epiderme da face adaxial espessa $(13,0 \pm 1,7 \mu \mathrm{m}$ de espessura), tamanho semelhante à epiderme da face abaxial, fibras subepidérmicas organizadas em grupos isolados (Fig. 4D); papilas presentes em ambas as faces (mais abundantes abaxialmente); células comuns da epiderme da face adaxial predominantemente retangulares, tamanho semelhante entre si, 1-2 vezes mais altas do que largas (Fig.

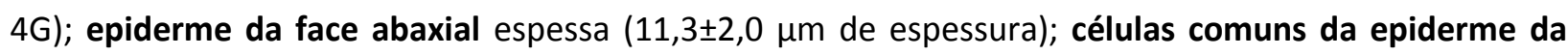
face abaxial predominantemente retangulares, de tamanho semelhante entre si, 1-2 vezes mais altas que largas (Fig. 4I); estômatos na região intercostal, em fileiras estomáticas contíguas (Fig. 4H); cristas estomáticas ausentes; células-guarda $2-3$ vezes mais compridas que largas $(32,5 \pm 2,0 \mu \mathrm{m}$ de comprimento e 14,1 $\pm 1,0 \mu \mathrm{m}$ de largura); células subsidiárias reniformes; células buliformes retangulares, em grupos 2 vezes mais largo que alto, 2 camadas celulares (Fig. 4B); mesofilo dorsiventral clássico, 6-8 camadas de células (190,3 $\pm 26,5 \mu \mathrm{m}$ de espessura) (Fig. 4A); parênquima paliçádico com 2 camadas de células, mais de 4 vezes mais altas do que largas; parênquima lacunoso com células isodiamétricas; hipoderme adaxial espessa $(17,9 \pm 2,6 \mu \mathrm{m}$ de espessura), células ovoides (Fig. 4D); hipoderme abaxial delgada $(11,8 \pm 1,8 \mu \mathrm{m}$ de espessura), células ovoides (Fig. 4E); feixe vascular principal colateral, ovoide, livre ou semi-travado, tanto adaxial quanto abaxialmente; protoxilema voltado para a face adaxial; 1-2 vasos de metaxilema; floema situado apenas na parte inferior do xilema (Fig. 4B); feixes vasculares de primeira ordem travados, tanto adaxial quanto abaxialmente; feixes vasculares de segunda ordem travados, tanto adaxial quanto abaxialmente; feixes vasculares de terceira ordem livres adaxialmente e travados abaxialmente (Fig. 4A); feixes vasculares comissurais equidistantes de ambas as faces epidérmicas; grupos de fibras raros, formato obtriangular, 5-10 fibras por grupo, adjacentes à hipoderme adaxial em uma faixa descontínua (Fig. 4A); fibras do mesofilo de formato semelhante àquelas que ocorrem na bainha dos feixes vasculares; margem foliar arredondada; grupos de fibras marginais circulares, 1 único grupo ou 2 ou mais grupos de fibras (Fig. 4C).

$$
|\underline{\overline{\mathrm{P}}}\{\underline{\underline{\mathrm{T}}} \underline{\overline{\overline{\mathrm{S}}}} \underline{\underline{\mathrm{T}}}\} \underline{\underline{\overline{\mathrm{P}}}}|^{\mathrm{E}}|\mathrm{T}| \approx 50
$$

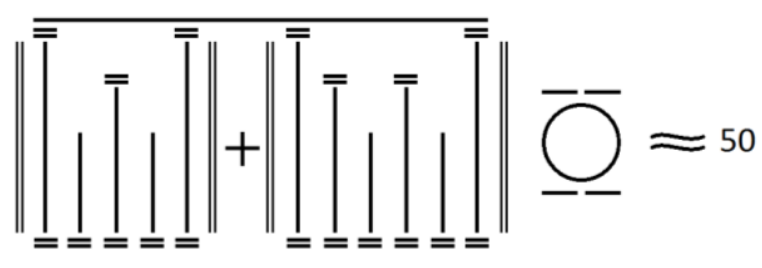

(Fig. 4F) 


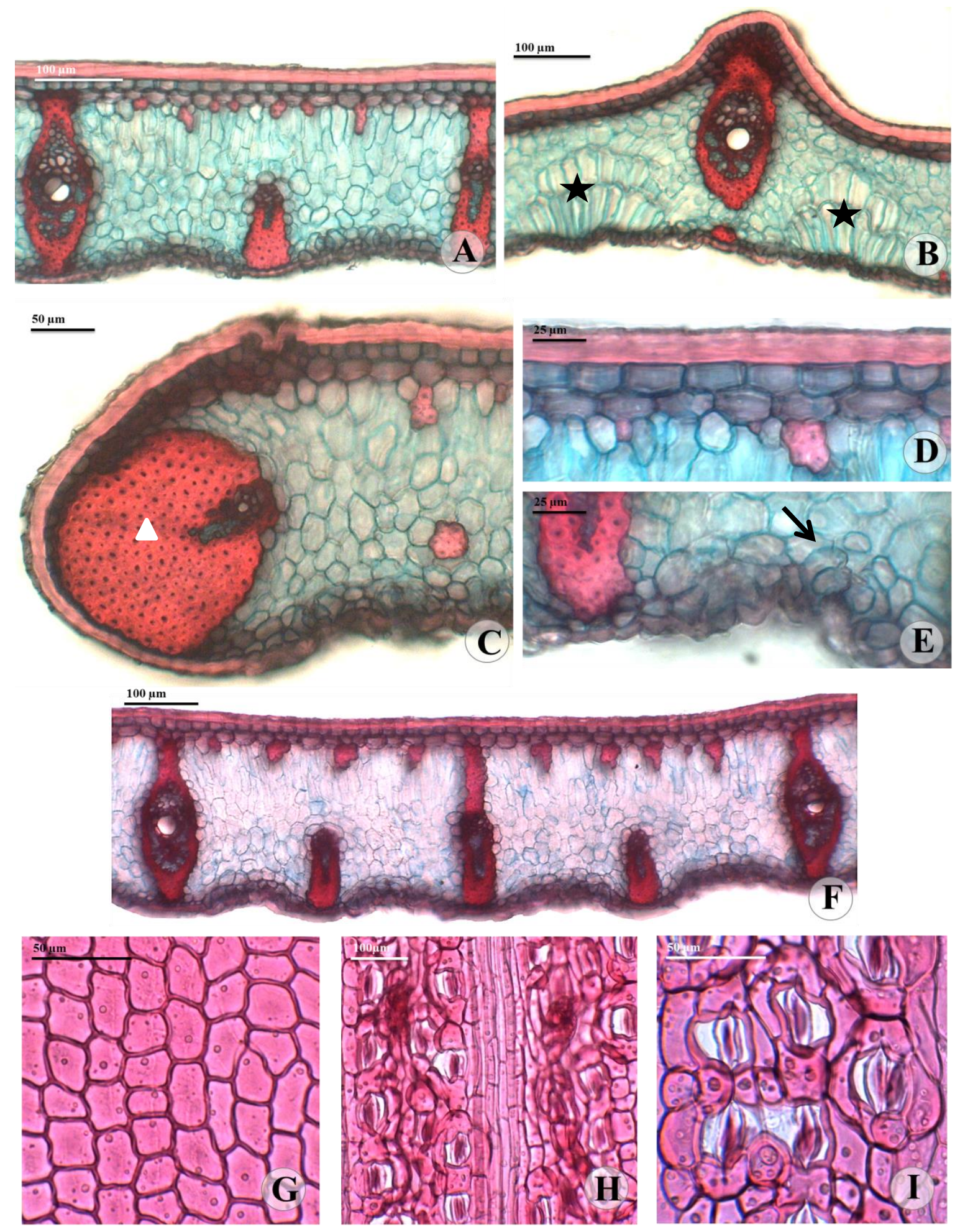

Fig. 4. Anatomia foliar de Allagoptera brevicalyx M. Moraes (Restinga) A-F: Secções transversais; G-I: Cortes paradérmicos. A. Visão geral da lâmina foliar (mesofilo dorsiventral clássico). B. Feixe vascular principal do segmento, evidenciando as células buliformes (estrelas). C. Margem do segmento foliar com grupo de fibras marginais (triângulo). D. Face adaxial do segmento. E. Face abaxial do segmento com complexo estomático (seta). F. Padrão dos feixes vasculares. G. Epiderme na face adaxial. H. Epiderme

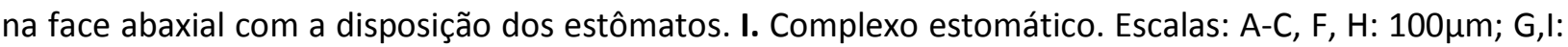
$50 \mu \mathrm{m} ; \mathrm{D}-\mathrm{E}: 25 \mu \mathrm{m}$. 
Lâmina foliar convexa adaxialmente e plana abaxialmente, face abaxial sem ondulações (Fig. $5 \mathrm{~A})$; epiderme da face adaxial mediana $(7,9 \pm 1,1 \mu \mathrm{m}$ de espessura), tamanho semelhante à epiderme da face abaxial, fibras subepidérmicas organizadas em uma faixa contínua (Fig. 5D); papilas presentes adaxialmente; células comuns da epiderme da face adaxial retangulares, tamanho variável entre si, relação altura:largura das células variável (Fig. 5G); epiderme da face abaxial delgada $(7,4 \pm 1,0 \mu \mathrm{m}$ de espessura); células comuns da epiderme da face abaxial quadrangulares a retangulares, tamanho variável entre si, 2-3 vezes mais altas que largas (Fig. 5I); estômatos nas regiões costal e intercostal, em uma única fileira estomática (Fig. $5 \mathrm{H}$ ); cristas estomáticas ausentes; células-guarda 2-3 vezes mais compridas que largas $(32,5 \pm 3,5 \mu \mathrm{m}$ de comprimento e 15,1 $\pm 2,0 \mu \mathrm{m}$ de largura); células subsidiárias em formato de cone; células buliformes hexagonais, em grupos tão largos quanto altos, 2 camadas celulares (Fig. 5B); mesofilo homogêneo, 5-7 camadas de células (184,0 $\pm 15,2 \mu \mathrm{m}$ de espessura) (Fig. 5A); parênquima clorofiliano sem espaços intercelulares; hipoderme adaxial mediana $(15,4 \pm 2,3 \mu \mathrm{m}$ de espessura), células ovoides (Fig. 5D); hipoderme abaxial delgada $(9,6 \pm 0,6 \mu \mathrm{m}$ de espessura), células retangulares a ovoides (Fig. 5E); feixe vascular principal bicolateral, circular, travado adaxial e semitravado abaxialmente; protoxilema situado ao centro da nervura e adaxialmente; 1-2 vasos de metaxilema; floema situado apenas na parte inferior do xilema (Fig. 5B); feixes vasculares de primeira ordem travados adaxialmente e travados ou semi-travados abaxialmente; feixes vasculares de segunda ordem travados, tanto adaxial quanto abaxialmente; feixes vasculares de terceira ordem travados, tanto adaxial quanto abaxialmente; feixes vasculares de quarta ordem travados ou livres adaxialmente e travados abaxialmente (Fig. 5A); feixes vasculares comissurais localizados mais adaxialmente na lâmina; grupos de fibras abundantes, formato obtriangular, mais de 10 fibras por grupo, adjacentes à hipoderme adaxial em uma faixa contínua (Fig. 5A); fibras do mesofilo de formato semelhante àquelas que ocorrem na bainha dos feixes vasculares; margem foliar inclinada; grupos de fibras marginais triangulares, 1 único grupo de fibras (Fig. 5C).

$$
\begin{aligned}
& \left|\underline{\overline{\mathrm{P}}}\{\underline{\underline{\mathrm{Q}}} \overline{\overline{\mathrm{T}}} \underline{\underline{Q}}\}_{3} \underline{\overline{\mathrm{S}}}\{\underline{\underline{\mathrm{Q}}} \overline{\overline{\mathrm{T}}} \underline{\underline{Q}}\}_{3} \underline{\overline{\mathrm{P}}}\right|^{\mathrm{E}}|\mathrm{I}| \approx 100
\end{aligned}
$$

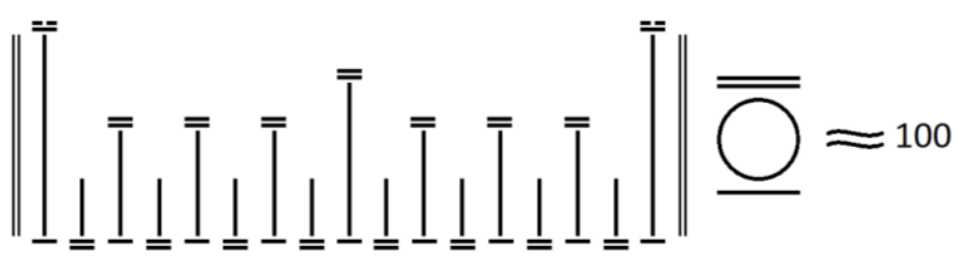

(Fig. 5F) 

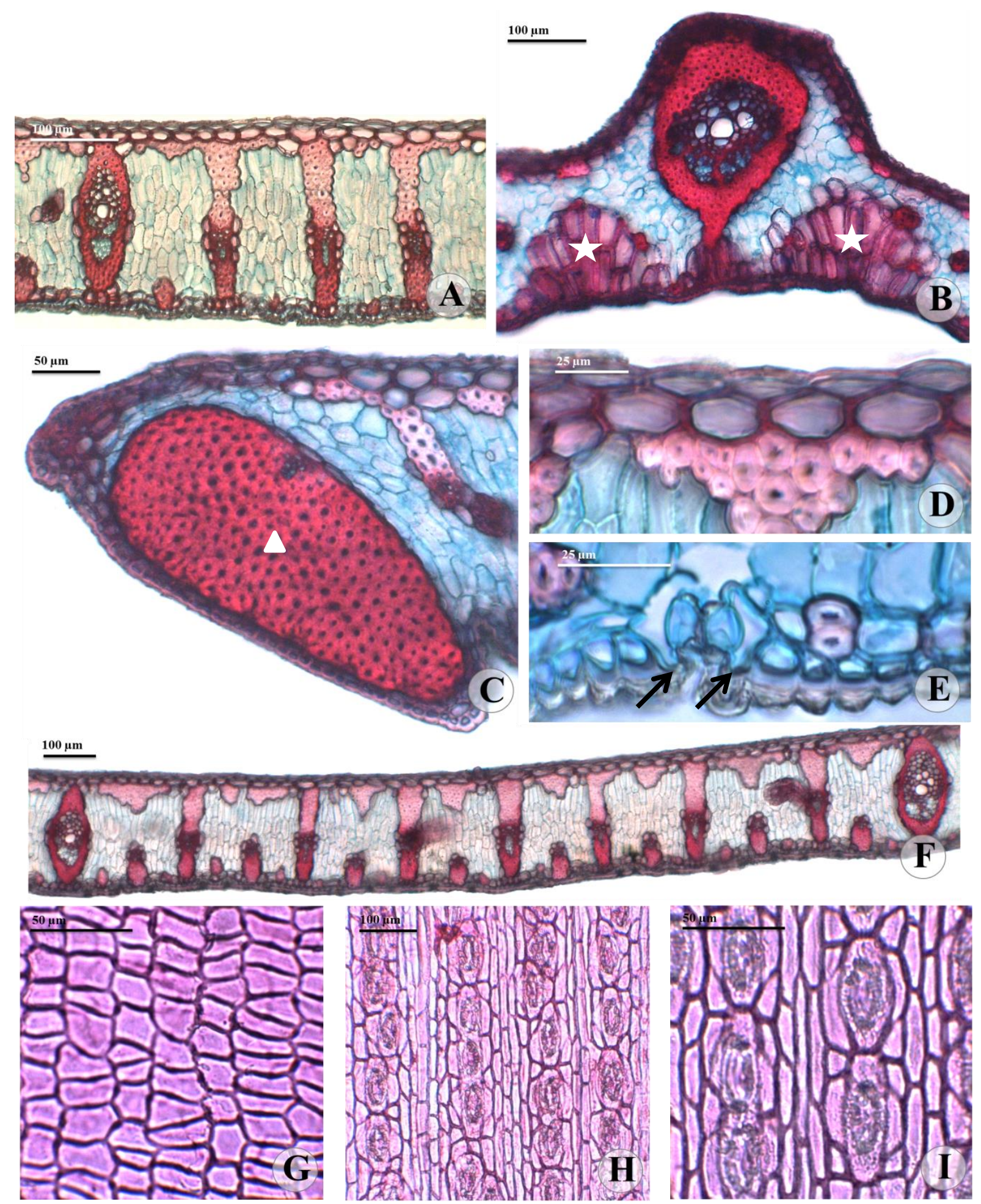

Fig. 5. Anatomia foliar de Allagoptera campestris (Mart.) Kuntze (Cerrado) A-F: Secções transversais; G-I: Cortes paradérmicos. A. Visão geral da lâmina foliar (mesofilo homogêneo). B. Feixe vascular principal do segmento, evidenciando as células buliformes (estrelas). C. Margem do segmento foliar com grupos de fibras marginais (triângulo). D. Face adaxial do segmento. E. Face abaxial do segmento com complexo estomático e cristas subsidiárias (setas). F. Padrão dos feixes vasculares. G. Epiderme na face adaxial. H. Epiderme na face abaxial com a disposição dos estômatos. I. Complexo estomático. Escalas: A-C, F, H: $100 \mu \mathrm{m} ; \mathrm{G}, \mathrm{I}: 50 \mu \mathrm{m} ; \mathrm{D}-\mathrm{E}: 25 \mu \mathrm{m}$. 
Lâmina foliar convexa adaxialmente e côncava abaxialmente, face abaxial acentuadamente sulcada (Fig. 6A); epiderme da face adaxial delgada $(7,4 \pm 1,3 \mu \mathrm{m}$ de espessura), tamanho semelhante à epiderme da face abaxial, fibras subepidérmicas organizadas em grupos isolados (Fig. 6D); papilas presentes abaxialmente; células comuns da epiderme da face adaxial predominantemente retangulares, tamanho semelhante entre si, 2-3 vezes mais largas que altas (Fig. 6G); epiderme da face abaxial mediana $(8,3 \pm 1,5 \mu \mathrm{m}$ de espessura); células comuns da epiderme da face abaxial ovoides a retangulares, tamanho variável entre si, relação altura:largura variável (Fig. 6I); estômatos na região intercostal, em 2 fileiras estomáticas (Fig. 6H); cristas estomáticas ausentes; células-guarda 2-3 vezes mais compridas que largas $(27,1 \pm 3,6 \mu \mathrm{m}$ de comprimento e $12,7 \pm 3,4 \mu \mathrm{m}$ de largura); células subsidiárias curto triangulares; células buliformes retangulares, em grupos 3 vezes mais largos que altos, 3 camadas celulares (Fig. 6B); mesofilo dorsiventral clássico, 5-8 camadas de células $(185,5 \pm 35,4$ $\mu \mathrm{m}$ de espessura) (Fig. 6A); parênquima paliçádico com 1-2 camadas de células, 2-3 vezes mais altas que largas; parênquima lacunoso com células isodiamétricas; hipoderme adaxial mediana $(14,1 \pm 1,4 \mu \mathrm{m}$ de espessura), células circulares a ovoides (Fig. 6D); hipoderme abaxial espessa $(18,5 \pm 3,3 \mu \mathrm{m}$ de espessura), células circulares (Fig. 6E); feixe vascular principal com organização do tipo atactostelo, ovoide, travado adaxial e livre abaxialmente; protoxilema situado ao centro da lâmina e adaxialmente; um único vaso de metaxilema; floema na parte inferior do xilema e entre os vasos xilemáticos adaxiais (Fig. 6B); feixes vasculares de primeira ordem semi-travados adaxialmente e livres abaxialmente; feixes vasculares de segunda ordem livres adaxialmente e semi-travados abaxialmente; feixes vasculares de terceira ordem livres adaxialmente e travados abaxialmente; feixes vasculares de quarta ordem livres adaxialmente e travados abaxialmente (Fig. 6A); feixes vasculares comissurais equidistantes de ambas as faces; grupos de fibras frequentes, formato obtriangular, 5-10 fibras por grupo, adjacentes à hipoderme adaxial em uma faixa descontínua (Fig. 6A); fibras do mesofilo de formato distinto daquelas que ocorrem na bainha dos feixes vasculares; margem foliar arredondada; grupos de fibras marginais ausentes (Fig. 6C).

$$
\mid \underline{\overline{\mathrm{P}}}\left\{\underline { \underline { \mathrm { Q } } } \underline { \underline { \mathrm { Q } } } \underline { \underline { \underline { \mathrm { S } } } } \left\{\left.\underline{\underline{\mathrm{Q}}}\{\underline{\underline{\mathrm{T}}} \underline{\underline{\mathrm{Q}}}\} \underline{\overline{\mathrm{P}}}\right|^{\mathrm{E}}|\mathrm{T}| \approx 120\right.\right.
$$

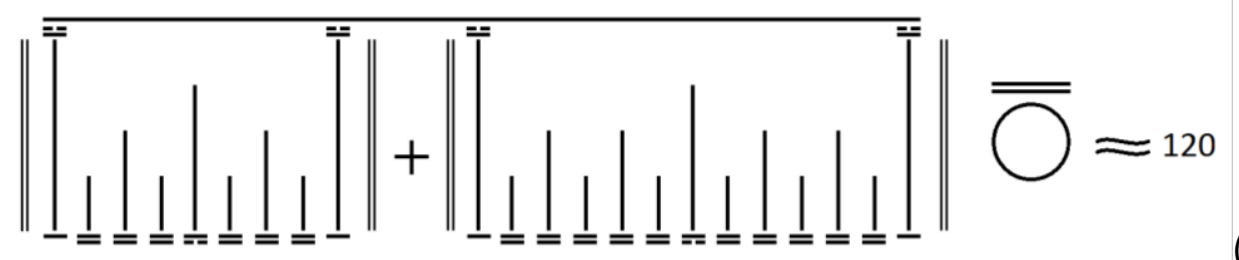

(Fig. 6F) 

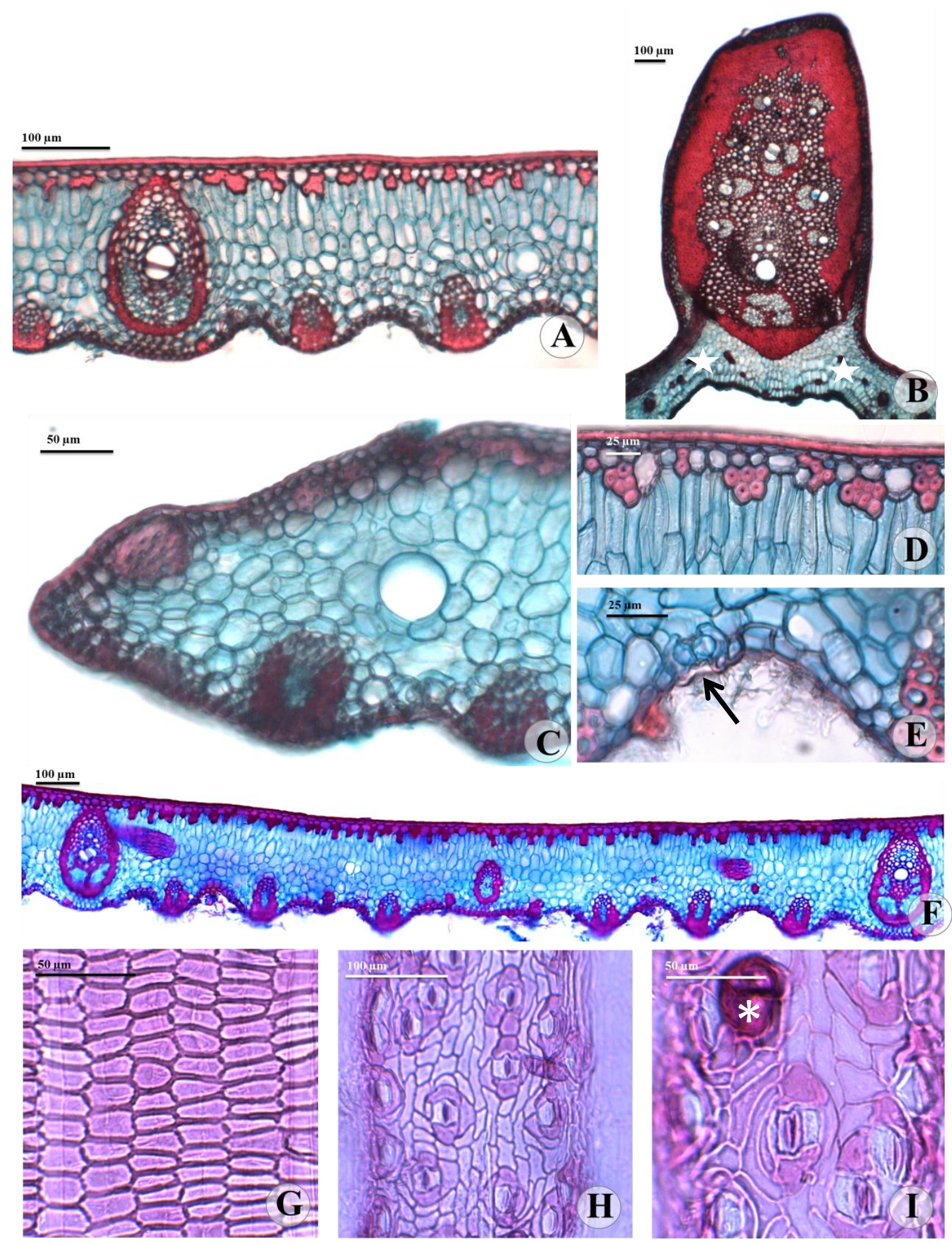

Fig. 6. Anatomia foliar de Allagoptera caudescens (Mart.) Kuntze (Mata Atlântica) A-F: Secções transversais; G-I: Cortes paradérmicos. A. Visão geral da lâmina foliar (mesofilo dorsiventral clássico). B. Feixe vascular principal do segmento, evidenciando as células buliformes (estrelas). C. Margem do segmento foliar. D. Face adaxial do segmento. E. Face abaxial do segmento com complexo estomático (seta). F. Padrão dos feixes vasculares. G. Epiderme na face adaxial. H. Epiderme na face abaxial com a

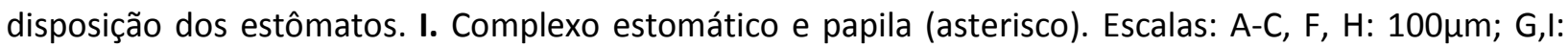
$50 \mu \mathrm{m} ; \mathrm{D}-\mathrm{E}: 25 \mu \mathrm{m}$. 
Lâmina foliar convexa adaxialmente e côncava adaxialmente, face abaxial sem ondulações (Fig. $7 \mathrm{~A})$; epiderme da face adaxial delgada $(6,9 \pm 1,0 \mu \mathrm{m}$ de espessura), tamanho semelhante à epiderme da face abaxial, fibras subepidérmicas organizadas em grupos isolados (Fig. 7D); papilas presentes adaxialmente; células comuns da epiderme da face adaxial quadrangulares a retangulares, tamanho semelhante entre si, 1 -2 vezes mais largas que altas (Fig. $7 G$ ); epiderme da face abaxial delgada $(5,7 \pm 1,3$ $\mu \mathrm{m}$ de espessura); células comuns da epiderme da face abaxial predominantemente retangulares, tamanho semelhante entre si, 2-3 vezes mais altas que largas (Fig. 7l); estômatos na região intercostal, em 1-2 fileiras estomáticas (Fig. 7H); cristas estomáticas ausentes; células-guarda 2-3 vezes mais compridas que largas $(28,0 \pm 0,9 \mu \mathrm{m}$ de comprimento e $11,1 \pm 1,2 \mu \mathrm{m}$ de largura); células subsidiárias em forma de "V"; células buliformes retangulares, em grupos 2 vezes mais largos que altos, 2 camadas celulares (Fig. 7B); mesofilo dorsiventral gradativo, 4-6 camadas de células $(126,3 \pm 13,9 \mu \mathrm{m}$ de espessura) (Fig. 7A); parênquima clorofiliano com espaços intercelulares ausentes; hipoderme adaxial delgada (13,1 $\pm 1,8 \mu \mathrm{m}$ de espessura), células ovoides (Fig. 7D); hipoderme abaxial delgada $(10,0 \pm 2,1 \mu \mathrm{m}$ de espessura), células circulares a ovoides (Fig. 7E); feixe vascular principal bicolateral, ovoide, travado adaxial e travado ou semi-travado abaxialmente; protoxilema situado ao centro da lâmina e adaxialmente; 2 vasos de metaxilema; floema na parte inferior do xilema e entre os vasos xilemáticos adaxiais (Fig. 7B); feixes vasculares de primeira ordem travados, tanto adaxial quanto abaxialmente; feixes vasculares de segunda ordem travados ou semi-travados adaxialmente e travados abaxialmente; feixes vasculares de terceira ordem livres adaxialmente e semi-travados abaxialmente; feixes vasculares de quarta ordem livres adaxialmente e semi-travados abaxialmente (Fig. 7A); feixes vasculares comissurais equidistantes de ambas as faces; grupos de fibras raros, formato obtriangular e elíptico deitado, menos de 5 fibras por grupo, adjacentes à hipoderme adaxial em uma faixa descontínua (Fig. 7A); fibras do mesofilo de formato distinto daquelas que ocorrem na bainha dos feixes vasculares; margem foliar inclinada; grupos de fibras marginais ovoides, 1 único grupo de fibras (Fig. 7C).

$$
\begin{aligned}
& |\underline{\overline{\mathrm{P}}}\{\underline{\mathrm{Q}} \underline{\mathrm{T}} \underline{\mathrm{Q}}\} \overline{\mathrm{S}}\{\underline{\mathrm{Q}} \underline{\mathrm{T}} \underline{\mathrm{Q}}\} \underline{\overline{\mathrm{P}}}|^{\mathrm{E}}|\mathrm{J}| \approx 70 \\
& \|\|_{1}\left|I_{1}\right| I_{1} \| \overline{\underline{O}}=0
\end{aligned}
$$



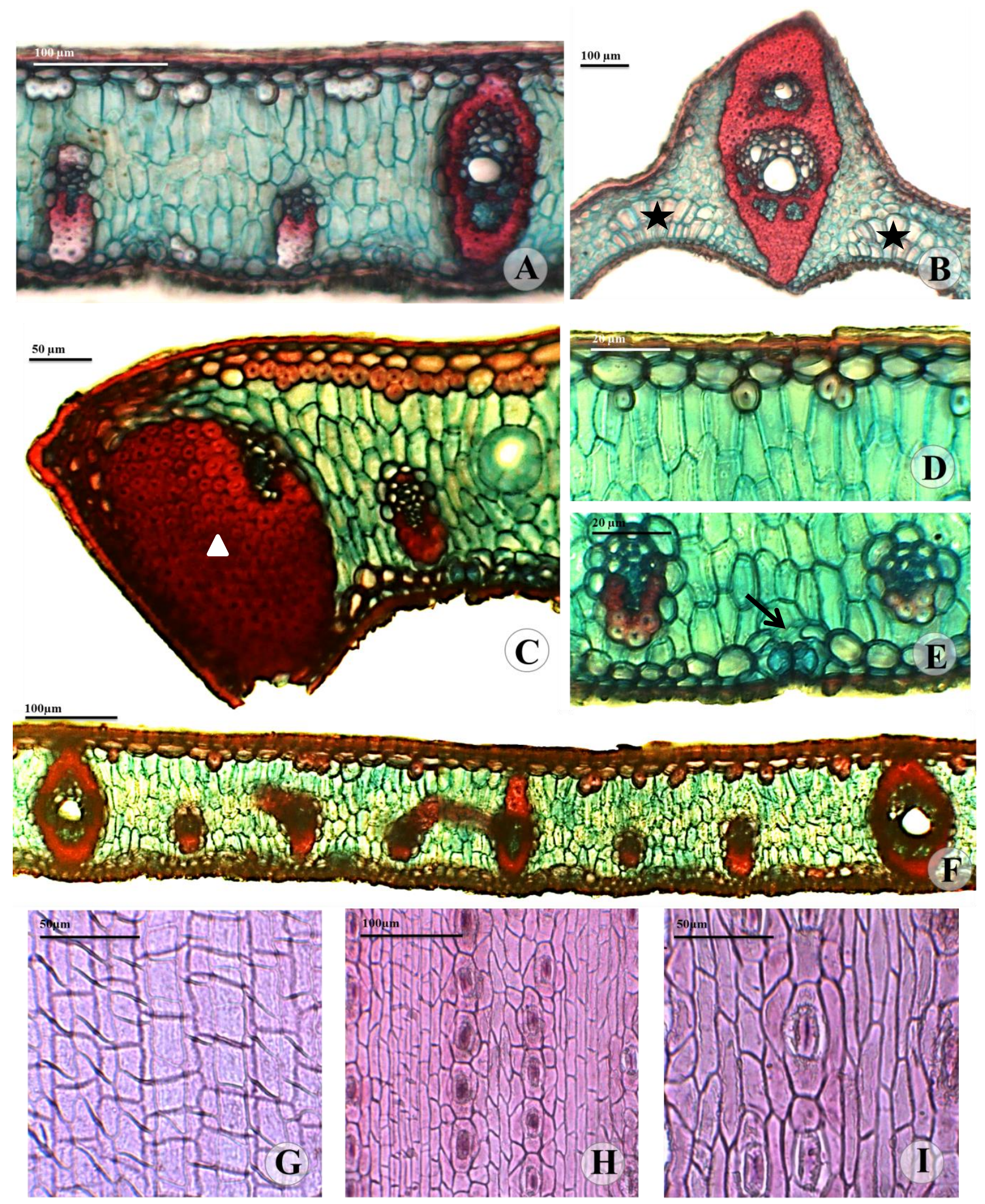

Fig. 7. Anatomia foliar de Allagoptera leucocalyx (Drude) Kuntze (Cerrado) A-F: Secções transversais; G-I: Cortes paradérmicos. A. Visão geral da lâmina foliar (mesofilo dorsiventral gradativo). B. Feixe vascular principal do segmento, evidenciando as células buliformes (estrelas). C. Margem do segmento foliar com grupos de fibras marginais (triângulo). D. Face adaxial do segmento. E. Face abaxial do segmento com complexo estomático (seta). F. Padrão dos feixes vasculares. G. Epiderme na face adaxial. H. Epiderme

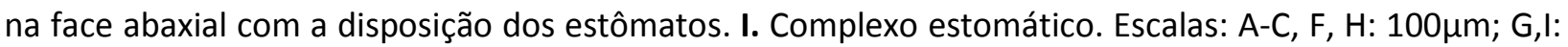
$50 \mu \mathrm{m} ; \mathrm{D}-\mathrm{E}: 20 \mu \mathrm{m}$. 
Lâmina foliar convexa adaxialmente e plana abaxialmente, face abaxial sem ondulações (Fig. $8 \mathrm{~A})$; epiderme da face adaxial mediana $(8,2 \pm 1,1 \mu \mathrm{m}$ de espessura), mais delgada que a epiderme da face abaxial, fibras subepidérmicas organizadas em uma faixa contínua (Fig. 8D); papilas presentes adaxialmente; células comuns da epiderme da face adaxial retangulares a ovoides, tamanho semelhante entre si, relação largura:altura variável (Fig. 8G); epiderme da face abaxial espessa (11,0 $\pm 1,6 \mu \mathrm{m}$ de espessura); células comuns da epiderme da face abaxial retangulares, tamanho semelhante entre si, mais de 3 vezes mais altas que largas (Fig. 8I); estômatos na região intercostal, em 2-3 fileiras estomáticas (Fig. 8H); cristas estomáticas presentes; células-guarda 2-3 vezes mais compridas que largas $(38,8 \pm 1,4 \mu \mathrm{m}$ de comprimento e $16,6 \pm 0,8 \mu \mathrm{m}$ de largura); células subsidiárias reniformes; células buliformes retangulares, em grupos tão largos quanto altos, 3 camadas celulares (Fig. 8B); mesofilo homogêneo, 4-7 camadas de células $(292,6 \pm 44,7 \mu \mathrm{m}$ de espessura) (Fig. 8A); parênquima clorofiliano com espaços intercelulares presentes; hipoderme adaxial espessa $(16,1 \pm 2,3$ $\mu \mathrm{m}$ de espessura), células ovoides (Fig. 8D); hipoderme abaxial mediana $(14,4 \pm 2,6 \mu \mathrm{m}$ de espessura), células circulares a ovoides (Fig. 8E); feixe vascular principal colateral ou bicolateral, circular, travado adaxial e livre ou semi-travado abaxialmente; protoxilema situado ao centro da lâmina e adaxialmente; 1-2 vasos de metaxilema; floema apenas na parte inferior do xilema (Fig. 8B); feixes vasculares de primeira ordem semi-travados, tanto adaxial quanto abaxialmente; feixes vasculares de segunda ordem travados ou semi-travados, tanto adaxial quanto abaxialmente; feixes vasculares de terceira ordem travados adaxialmente e semi-travados abaxialmente; feixes vasculares de quarta ordem livres adaxialmente e travados abaxialmente (Fig. 8A); feixes vasculares comissurais equidistantes de ambas as faces; grupos de fibras abundantes, formato obtriangular e elíptico deitado, mais de 10 fibras por grupo, adjacentes à hipoderme adaxial em uma faixa contínua (Fig. 8A); fibras do mesofilo de formato semelhante àquelas que ocorrem na bainha dos feixes vasculares; margem foliar inclinada; grupos de fibras marginais ovoides, 1 único grupo de fibras (Fig. 8C).

$$
\begin{aligned}
& |\underline{\underline{P}}\{\underline{\underline{Q}} \overline{\bar{T}} \underline{\underline{Q}}\} \underline{\bar{S}}\{\underline{\underline{Q}} \overline{\bar{T}} \underline{\underline{Q}}\} \underline{\bar{P}}|^{E}|I| \approx 70
\end{aligned}
$$

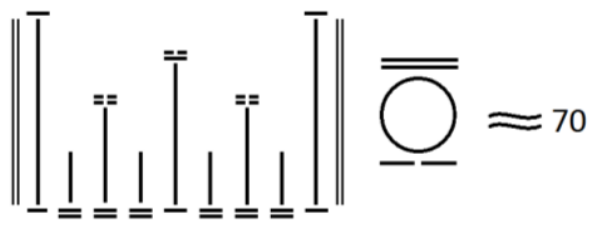

(Fig. 8F) 

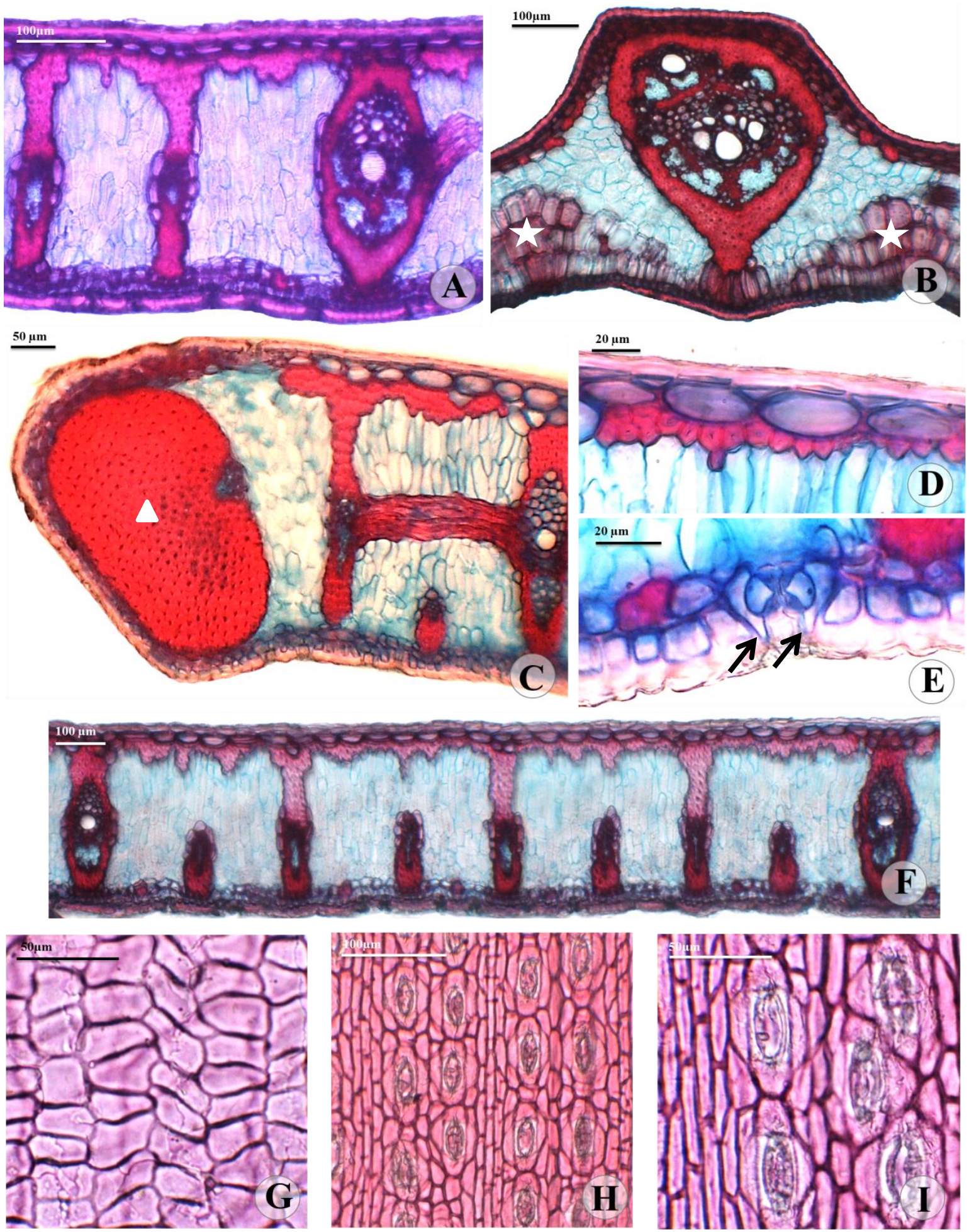

Fig. 8. Anatomia foliar de Allagoptera robusta Martins R. C. \& Filg. (Cerrado) A-F: Secções transversais; G-I: Cortes paradérmicos. A. Visão geral da lâmina foliar (mesofilo homogêneo). B. Feixe vascular principal do segmento, evidenciando as células buliformes (estrelas). C. Margem do segmento foliar com grupos de fibras marginais (triângulo). D. Face adaxial do segmento. E. Face abaxial do segmento com complexo estomático e cristas subsidiárias (setas). F. Padrão dos feixes vasculares. G. Epiderme na face adaxial. H. Epiderme na face abaxial com a disposição dos estômatos. I. Complexo estomático. Escalas: A-C, F, H: $100 \mu \mathrm{m} ; \mathrm{G}, \mathrm{I}: 50 \mu \mathrm{m} ; \mathrm{D}-\mathrm{E}: 20 \mu \mathrm{m}$. 


\section{Análises histoquímicas}

As análises histoquímicas indicaram a presença de muitos compostos fenólicos, e os testes também deram positivos para a análise específica de taninos (Fig. 9 e Fig. 10).
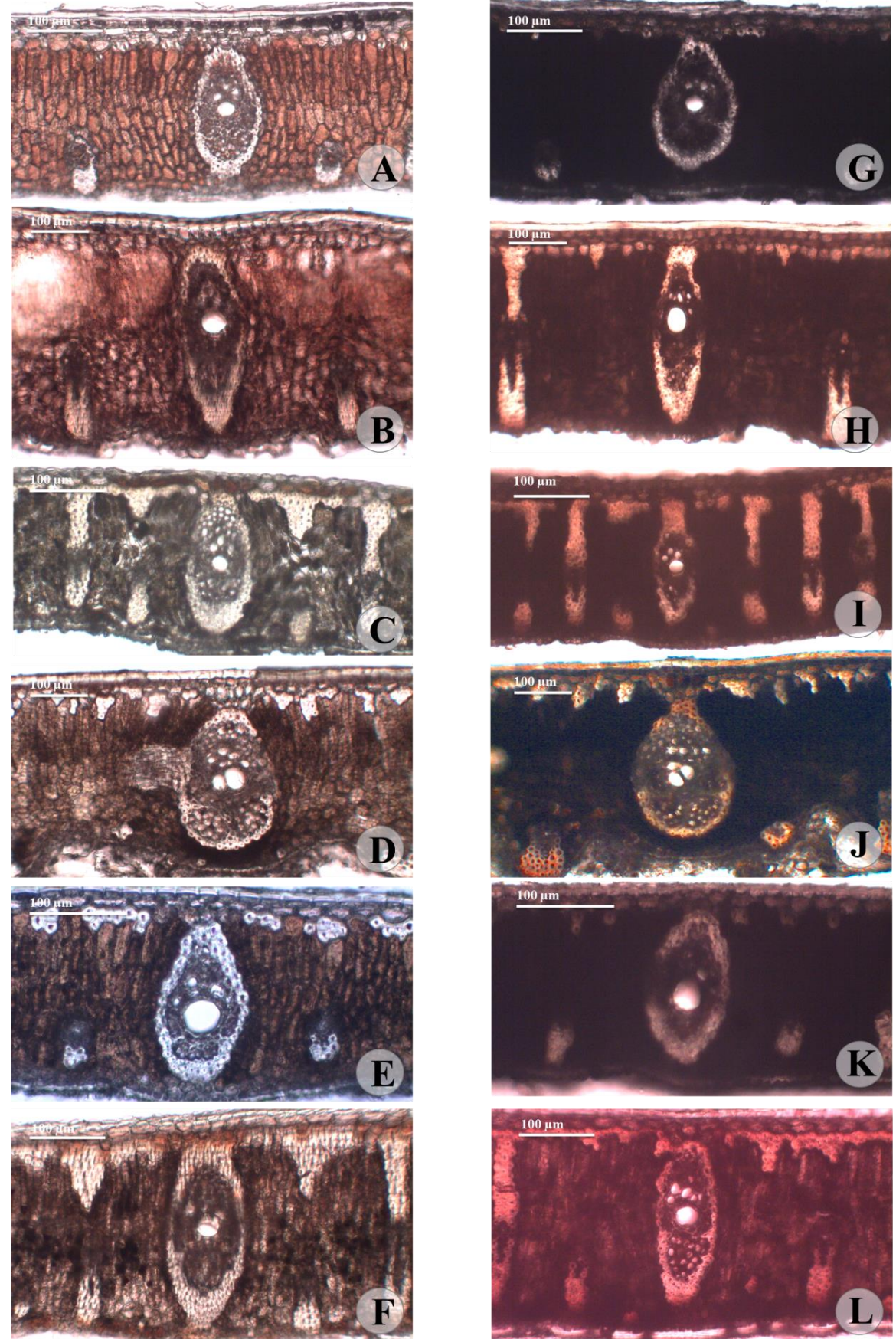

Fig. 9. Análise histoquímica de compostos fenólicos em Allagoptera (Arecaceae). A-F: controle; G-L: coloração com cloreto de ferro a $10 \%$, evidenciando os compostos fenólicos. A, G - Allagoptera arenaria (Gomes) Kuntze; B, H - Allagoptera brevicalyx M. Moraes; C, I -Allagoptera campestris (Mart.) Kuntze; D, J - Allagoptera caudescens (Mart.) Kuntze; E, K - Allagoptera leucocalyx (Drude) Kuntze; F, L Allagoptera robusta Martins \& Filgueiras. Escala: $100 \mu \mathrm{m}$ 

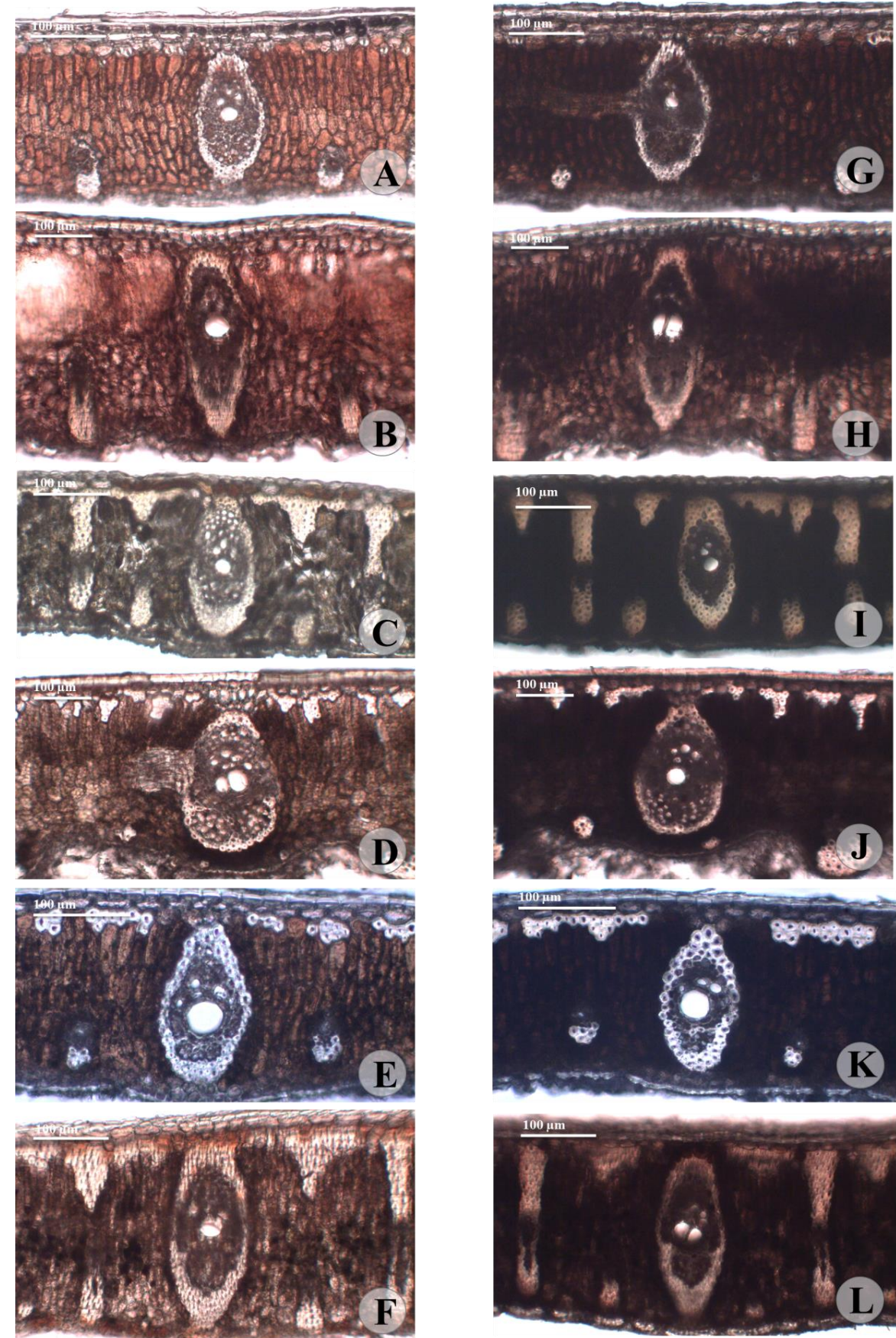

Fig. 10. Análise histoquímica de taninos em Allagoptera (Arecaceae). A-F: controle; G-L: coloração com solução aquosa concentrada de sulfato ferroso, evidenciando os taninos. A, G - Allagoptera arenaria (Gomes) Kuntze; B, H - Allagoptera brevicalyx M. Moraes; C, I - Allagoptera campestris (Mart.) Kuntze; D, J - Allagoptera caudescens (Mart.) Kuntze; E, K - Allagoptera leucocalyx (Drude) Kuntze; F, L Allagoptera robusta Martins \& Filgueiras. Escala: $100 \mu \mathrm{m}$ 


\section{Chave de identificação anatômica das espécies de Allagoptera Nees}

1. Lâmina foliar sem ondulações abaxialmente, mesofilo homogêneo, grupos de fibras abundantes, em uma faixa contínua

2. Epiderme nas duas faces com espessuras semelhantes entre si, células comuns da epiderme de tamanho fortemente desuniforme entre si, estômatos em uma única fileira, feixe vascular principal bicolateral

Allagoptera campestris

2'. Epiderme na face adaxial mais delgada que na abaxial, células comuns da epiderme de tamanho semelhante entre si, estômatos em 2-3 fileiras, feixe vascular principal colateral ou bicolateral

Allagoptera robusta

1'. Lâmina foliar sulcada ou com leves depressões abaxialmente, mesofilo dorsiventral clássico ou dorsiventral gradativo, grupos de fibras raros ou frequentes, isolados ou em uma faixa quase contínua

3. Lâmina foliar sulcada abaxialmente, papilas presentes na face abaxial, estômatos em duas fileiras

4. Lâmina foliar côncavo-convexa, hipoderme adaxial de tamanho semelhante ou mais delgada que hipoderme abaxial, feixes vasculares de quatro ordens de grandeza, sendo o feixe vascular principal do tipo atactostelo, grupos de fibras marginais ausentes

Allagoptera caudescens

4'. Lâmina foliar plano-convexa, hipoderme adaxial de tamanho semelhante ou mais espessa que hipoderme abaxial, feixes vasculares de três ordens de grandeza, sendo o feixe vascular principal do tipo colateral, grupos de fibras marginais presentes

Allagoptera brevicalyx

3'. Lâmina foliar com leves depressões abaxialmente, papilas ausentes na face abaxial, estômatos em 1 ou 3 fileiras 
5. Epiderme com espessura $>7,5 \mu \mathrm{m}$, hipoderme com espessura $>14,0 \mu \mathrm{m}$, células comuns da epiderme de tamanho variável entre si, mesofilo dorsiventral clássico, feixe vascular principal do tipo colateral, grupos de fibras frequentes, em uma faixa praticamente contínua

Allagoptera arenaria

5'. Epiderme com espessura $<7,5 \mu \mathrm{m}$, hipoderme com espessura $<14,0 \mu \mathrm{m}$, células comuns da epiderme de tamanho semelhante entre si, mesofilo dorsiventral gradativo, feixe vascular principal do tipo bicolateral, grupos de fibras raros, em grupos isolados

Allagoptera leucocalyx 
Epiderme uniestratificada em ambas as faces foliares, com parede externa espessada adaxialmente, foi observada em todas as espécies do gênero, tal como observado por Moraes (1996) para A. arenaria, A. brevicalyx - espécies de Restinga -, A. campestris e A. leucocalyx - espécies de Cerrado. A cutícula fina descrita para o gênero por esta autora, no entanto, é um caracter um tanto subjetivo. Pôde-se observar que, para A. campestris, o complexo cutícula-parede periclinal externa foi realmente muito delgado, porém esta estrutura apresentou-se bastante espessa em $A$. brevicalyx, principalmente na epiderme adaxial (comparar Fig. 4D e Fig. 5D).

Para todas as espécies, não foram observadas ondulações, nem irregularidades na superfície da lâmina adaxialmente, ao passo que abaxialmente constatou-se uma variação entre as espécies. A ausência de ondulações e a maior espessura do complexo cutícula-parede periclinal externa na epiderme da face adaxial pode ser explicada pela maior irradiação luminosa a que esta face está exposta (Fahn, 1982). Abaxialmente, as ondulações observadas em algumas espécies formam um padrão em que os estômatos situam-se nas depressões. Ambas as espécies de Restinga (A. arenaria e A. brevicalyx) apresentaram este padrão, além da espécie de Mata Atlântica A. caudescens. Estes resultados nos levam a pensar que a Restinga pode impor restrições hídricas a determinadas espécies ainda mais severas que o Cerrado.

A espessura da epiderme variou muito entre as espécies, sendo mais espessa nas duas espécies de Restinga - A. brevicalyx adaxialmente e $A$. arenaria abaxialmente - e mais delgada em uma espécie de Cerrado - A. leucocalyx, tanto adaxial quanto abaxialmente. Santiago et al. (2001) sugerem que a espessura da epiderme está diretamente relacionada com a exposição ou não da planta ao sol, o que é corroborado pelos resultados verificados, posto que A. brevicalyx e A. arenaria são plantas que crescem em pleno sol, enquanto $A$. leucocalyx é uma espécie de sub-bosque (Moraes, 1996).

O complexo cutícula-parede periclinal externa apresentou-se da mesma espessura ou um pouco mais espesso que o protoplasto, tanto adaxial quanto abaxialmente, com exceção de A. campestris, onde a estrutura foi muito delgada. Em A. brevicalyx, foi observado um complexo cutícula-parede periclinal externa bastante espesso adaxialmente. Os ambientes em que as espécies foram coletadas ( $A$. campestris: Cerrado; A. brevicalyx: Restinga) estão ambos sujeitos a períodos de estresse hídrico, o que pode explicar a maior espessura do complexo cutícula-parede periclinal externa com relação ao protoplasto (Fahn, 1982; Barfod, 1988). No entanto, não podemos fazer afirmações com segurança a respeito dessa estrutura para $A$. brevicalyx, tendo em vista que, para esta espécie, as análises foram 
realizadas a partir de material herborizado. A. campestris parece ter preferência por locais mais sombreados (Martins, 2012), o que pode estar relacionado com a cutícula mais delgada nessa espécie.

Todas as espécies apresentaram papilas na epiderme adaxial, com exceção de $A$. caudescens, cujas papilas foram restritas à epiderme abaxial. Para A. brevicalyx, as papilas ocorreram em ambas as faces da epiderme foliar. Embora nenhuma das espécies tenha apresentado tricomas visíveis sob microscópio óptico, essas estruturas podem ser observadas sob microscopia eletrônica em algumas das espécies (Martins et al., 2015). De um modo geral, papilas são estruturas observadas em folhas de plantas xeromórficas (Cutler et al., 2008), o que pode explicar a presença dessas estruturas nas células das espécies analisadas. A presença dessas estruturas nas duas faces da epiderme foliar de A. brevicalyx, espécie de Restinga, indica que o ambiente em que esta espécie se encontra está sujeito a condições mais extremas que o ambiente onde ocorrem as demais espécies, o que reforça a ideia de que, para determinadas espécies, a Restinga é um ambiente mais hostil que o Cerrado. Já para A. caudescens, espécie de Mata Atlântica, as papilas restritas à face abaxial foi algo curioso, que pode ilustrar a descrição de Fahn (1982) de que papilas nem sempre estão relacionadas com adaptações a ambientes secos, podendo se especializar para desempenhar outras funções.

O complexo estomático do tipo tetracítico, observado para todas as espécies de Allagoptera, revelou ser típico de palmeiras (células-guarda rodeadas por quatro células subsidiárias - duas laterais e duas terminais). Embora Martins et al. (2015) relate estômatos do tipo anomocito para A. campestris, tal tipo de complexo estomático não foi observado para os espécimes analisados. Embora Tomlinson et al. (2011) tenham relatado que os estômatos das palmeiras não necessariamente ocorram em fileiras longitudinais regulares e contínuas, tal constatação não foi observada para Allagoptera. As fileiras estomáticas apresentaram uma variação entre as espécies, quanto à posição e quanto à distribuição.

Em geral, as cristas são encontradas nas células-guarda dos estômatos, sendo denominadas cristas estomáticas (Appezzato-da-Glória \& Carmello-Guerreiro, 2009), sendo constituídas por projeções cuticulares nas células-guarda, na face voltada para o ostíolo. Cristas estomáticas foram observadas por Tomlinson (1961) para as células-guarda da tribo Cocoseae e também ocorrem nas plantas aqui estudadas. Porém, uma característica interessante observada foi a presença de cristas nas células subsidiárias estomáticas, aqui denominadas cristas subsidiárias. Estas estruturas são constituídas por projeções das células subsidiárias que "abraçam" as células-guarda e se elevam, formando um bordo saliente ao redor das células-guarda (Fig. 5E e Fig. 8E). Esta parece ser uma nova característica anatômica, ainda não descrita na literatura, embora possam ser identificadas nas ilustrações de alguns trabalhos anatômico-foliares (Appezzato-da-Glória \& Carmello-Guerreiro, 2009; Oliveira \& Machado, 2009), notadamente nos gêneros Iris L. (Iridaceae Juss.) e Cymbopogon Spreng. (Poaceae). Em Arecaceae, estas estruturas foram observadas nos gêneros Chamaerops L., Trachycarpus H. Wendl. (Coryphoideae; Tomlinson et al., 2011) e Oenocarpus Mart. (Arecoideae; Silva \& Potiguara, 2008). As 
cristas subsidiárias parecem ser mais comuns que as cristas estomáticas em Arecaceae, evidenciando-se como uma peculiaridade anatômica de algumas espécies da família, sendo possivelmente uma sinapomorfia para determinados grupos.

A posição das células-guarda em depressões é uma característica que possibilita a existência de um microambiente úmido, reduzindo a taxa de transpiração foliar (Esau \& Morretes, 1974). Tanto as cristas estomáticas quanto as subsidiárias parecem ampliar o microambiente úmido e diminuir ainda mais a transpiração foliar, proporcionando economia de água.

Constatou-se que as células que compõem o tecido logo abaixo da região da nervura principal, denominadas nesse estudo "células buliformes", constituem estruturas homólogas às das Poaceae e apresentam a mesma função de expandir ou dobrar a lâmina foliar. Assim, é proposta uma padronização do uso dessa terminologia para a família Arecaceae. Diferentemente das células buliformes das gramíneas, no entanto, que em geral ocorrem na face adaxial da lâmina foliar, as células buliformes das palmeiras se apresentaram como estruturas conspícuas, ocorreram apenas na face abaxial e ocuparam quase toda a espessura da lâmina foliar, o que está de acordo com as observações realizadas para a tribo Cocoseae apresentadas por Tomlinson (1961).

Tomlinson et al. (2011) apontam que o mesofilo em Attaleinae é isobilateral ou dorsiventral, e Moraes (1996) observou que, para o gênero Allagoptera, o mesofilo é dorsiventral. Os mesofilos de $A$. brevicalyx (Restinga) e A. caudescens (Mata Atlântica) são claramente dorsiventrais, e a camada de células paliçádicas é bem evidente, conforme sugerem Tomlinson et al. (2011) (Fig. 4 e Fig. 6). Já A. campestris e $A$. robusta (espécies de Cerrado), em contraposição, apresentam mesofilos homogêneos (Fig. 5 e Fig. 8). Para A. arenaria (Restinga) e A. leucocalyx (Cerrado), observou-se que as células do mesofilo variavam muito ligeiramente em tamanho (Fig. 3 e Fig. 7). Esta variação ocorria de maneira gradativa, da face adaxial para a face abaxial, não sendo possível distinguir um parênquima paliçádico típico. Dessa maneira, é proposta aqui uma nova classificação em mesofilo dorsiventral clássico (parênquima paliçádico e lacunoso bem diferenciados entre si) e mesofilo dorsiventral gradativo (células do mesofilo diminuem gradativamente de tamanho).

Para todas as espécies, a hipoderme em geral apresentou-se bem desenvolvida e mais espessa que a epiderme, tanto adaxial quanto abaxialmente, à semelhança do observado por Tomlinson (1961) para o gênero Syagrus e por Tomlinson et al. (2011) para o gênero Cocos. No entanto, as células hipodérmicas apresentaram-se uniestratificadas, tanto adaxial quanto abaxialmente, em contraposição ao observado por Moraes (1996). Quando analisamos a camada epidérmica juntamente com a camada hipodérmica, percebemos que, enquanto Allagoptera brevicalyx apresentou tanto a epiderme quanto a hipoderme bem desenvolvidas, para $A$. robusta observou-se que as células hipodérmicas quase substituíram a camada epidérmica, sendo esta quase inexistente. Quando comparadas às células 
hipodérmicas, as células epidérmicas das palmeiras são quase sempre mais delgadas (Tomlinson et al., 2011).

Todas as espécies apresentaram hipoderme adaxial mais espessa que abaxial, exceto $A$. caudescens. Por habitar formações florestais mesofíticas, estas plantas estão sujeitas a intensidades luminosas e condições de estresse hídrico menores que as demais espécies analisadas (DeWalt et al., 2003; McElhinny et al., 2005). A hipoderme adaxial menos espessa é um estado de carácter presente em A. caudescens relacionado à ausência de pressões seletivas ambientais, que ocorrem nas nos habitats da demais espécies analisadas. A hipoderme abaxial dessa mesma espécie, no entanto, foi a mais espessa dentre todas, tendo sido observada nessa mesma face foliar a presença de papilas. Uma análise quanto às diferenças fisiológicas das duas faces epidérmicas da folha de $A$. caudescens seria um interessante estudo a ser realizado futuramente.

Observou-se que os feixes apresentam-se dispostos mais abaxialmente na lâmina foliar, o que coaduna com os resultados obtidos por Moraes (1996). No presente estudo, constatou-se que os feixes de primeira e segunda ordem encontram-se em contato com ambas as faces epidérmicas (exceto em $A$. caudescens, espécie de Mata Atlântica), os de terceira ordem, com uma ou ambas as faces epidérmicas e os de quarta ordem, apenas com a face abaxial. Tais observações estão de acordo com o apresentado por Tomlinson et al. (2011), que afirmam que os feixes longitudinais encontram-se em contato com uma ou ambas as faces epidérmicas em Attaleinae.

Analisando-se as fórmulas vasculares de todas as espécies (Fig. 11), ficam evidenciadas as diferenças relativas à classificação do mesofilo e dos feixes vasculares e o número aproximado de feixes entre uma margem foliar e outra. Ao mesmo tempo, observa-se que o padrão vascular é uma característica em comum entre as espécies. Todas as espécies apresentaram feixes vasculares de quatro ordens de grandeza, à exceção de $A$. brevicalyx, espécie de Restinga. A fórmula vascular aplicada evidenciou muitas diferenças entre as espécies, tornando possível uma comparação mais rápida entre estas, à semelhança do que ocorreu para espécies de Poaceae, conforme assinalado por Silva (2012). 
A. arenaria $|\overline{\underline{\mathrm{P}}}\{\underline{\underline{\mathrm{Q}}} \underline{\underline{\mathrm{T}}} \underline{\underline{\mathrm{Q}}}\} \underline{\overline{\mathrm{S}}}\{\underline{\underline{\mathrm{Q}}} \underline{\underline{\mathrm{T}}} \underline{\underline{\mathrm{Q}}}\} \underline{\overline{\mathrm{P}}}|^{\mathrm{E}}|\mathrm{J}| \approx 100$

A. brevicalyx $|\underline{\underline{\underline{\mathrm{P}}}}\{\underline{\underline{\underline{T}}} \underline{\underline{\overline{\mathrm{S}}}} \underline{\underline{\mathrm{T}}}\} \underline{\underline{\overline{\mathrm{P}}}}|^{\mathrm{E}}|\mathrm{T}| \approx 50$

A. campestris $\left|\underline{\overline{\mathrm{P}}}\{\underline{\underline{\mathrm{Q}}} \overline{\overline{\mathrm{T}}} \underline{\underline{\mathrm{Q}}}\}_{3} \underline{\overline{\mathrm{S}}}\{\underline{\underline{\mathrm{Q}}} \overline{\overline{\mathrm{I}}} \underline{\underline{\mathrm{Q}}}\}_{3} \underline{\overline{\overline{\mathrm{P}}}}\right|^{\mathrm{E}}|\mathrm{I}| \approx 100$

A. caudescens $|\underline{\overline{\mathrm{P}}}\{\underline{\underline{\mathrm{Q}}} \underline{\underline{\mathrm{T}}} \underline{\underline{\mathrm{Q}}}\} \underline{\underline{\mathrm{S}}}\{\underline{\underline{\mathrm{Q}}} \underline{\underline{\mathrm{T}}} \underline{\underline{\mathrm{Q}}}\} \underline{\overline{\mathrm{P}}}|^{\mathrm{E}}|\mathrm{T}| \approx 120$

A. leucocalyx $\mid \underline{\overline{\mathrm{P}}}\left\{\left.\underline{\underline{Q}} \underline{\underline{Q}} \underline{\underline{\mathrm{S}}}\{\underline{\underline{\mathrm{Q}}} \underline{\underline{\mathrm{Q}}}\} \underline{\overline{\mathrm{P}}}\right|^{\mathrm{E}}|\mathrm{J}| \approx 70\right.$

A. robusta $|\underline{\underline{\mathrm{P}}}\{\underline{\underline{\mathrm{Q}}} \underline{\overline{\overline{\mathrm{T}}}} \underline{\underline{\mathrm{Q}}}\} \underline{\overline{\mathrm{S}}}\{\underline{\underline{\mathrm{Q}}} \overline{\overline{\overline{\mathrm{T}}}} \underline{\underline{\mathrm{Q}}}\} \underline{\overline{\mathrm{P}}}|^{\mathrm{E}}|\mathrm{I}| \approx 70$

Fig. 11. Fórmulas Vasculares (FV) obtidas para as espécies de Allagoptera (Arecaceae).

Assim como a Fórmula Vascular, o Esquema Vascular é uma proposta que permite uma rápida comparação entre espécies com base em características gerais da lâmina foliar e dos feixes vasculares. Contudo, enquanto a Fórmula Vascular sintetiza por meio de uma fórmula geral o padrão vascular observado, o Esquema Vascular busca esquematizar este padrão por meio de um esboço simples da lâmina foliar A simbologia empregada por Silva (2012), embora prática, não evidencia tão rapidamente a organização e a altura dos feixes vasculares entre si na lâmina foliar. Além disso, verificou-se que, na mesma lâmina, feixes da mesma ordem apresentam mais de uma classificação quanto à sua ligação com a hipoderme, podendo ser travados ou semi-travados, semi-travados ou livres e até mesmo travados ou livres. Silva (2012) não propõe uma forma sintética de evidenciar essas faixas de variação existentes entre os feixes; a proposta inicial do autor, na verdade, era representar unicamente o padrão mais observado na lâmina foliar. A Fig. 12 ilustra os Esquemas Vasculares das espécies do gênero Allagoptera.

De uma maneira geral, as fibras apresentaram-se abundantes, com padrões de organização distintos na hipoderme adaxial, conforme apontado por Tomlinson (1961) para a tribo Cocoseae. De acordo com Tomlinson et al. (2011), as fibras em Attaleinae encontram-se sempre associadas à uma das faces hipodérmicas, podendo situar-se interna ou externamente a essa estrutura. Em Allagoptera, observou-se que $A$. caudescens (espécie de Mata Atlântica) foi a única espécie que apresentou fibras situadas internamente à hipoderme, tendo essas estruturas se situado externamente à hipoderme nas demais espécies. 
Verificou-se que a variação no formato, na frequência e no número de fibras em cada grupo foram caracteres que permitiram uma boa diferenciação entre as espécies. Da mesma forma, variações quanto a altura do grupo de fibras marginais também se apresentaram como características úteis para a distinção taxonômica dentro do gênero. Em Syagrus, as principais características distintivas entre as espécies são a margem foliar e a localização dos feixes vasculares e dos grupos de fibras com relação à margem (Noblick, 2013). Estudos como este evidenciam que as variações na margem foliar e nos grupos de fibras que ocorrem entre as espécies dos diferentes gêneros de Attaleinae podem apresentar grande importância taxonômica para esta subtribo.

Os testes histoquímicos evidenciaram a abundância de taninos nas células do mesofilo (Fig. 9 e Fig. 10), confirmando a constatação feita por Moraes (1996). Isto evidenciou que as espécies de Allagoptera realocam grande parte de seus metabólitos para defesa contra herbívoros e fitopatógenos. Um estudo que está em andamento verificou que, para diferentes estágios ontogenéticos de $A$. campestris, o investimento da planta em compostos fenólicos excede o gasto com açúcares (Pinedo, dados não publicados), o que indica que possivelmente o gênero possua uma estratégia de crescimento mais lento, porém defesa mais intensa.

A. arenaria

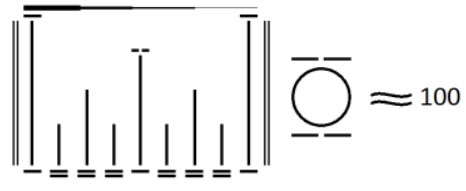

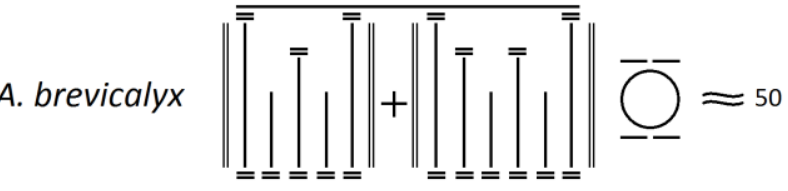

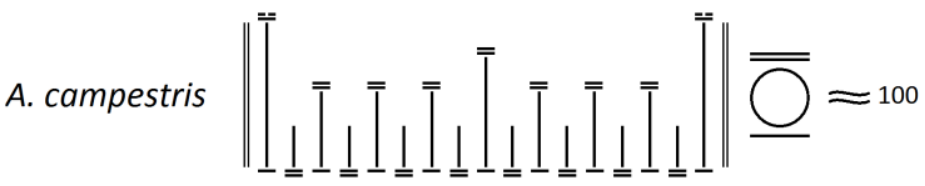

A. caudescens

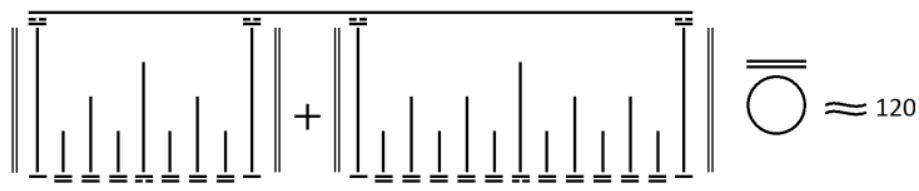

A. leucocalyx

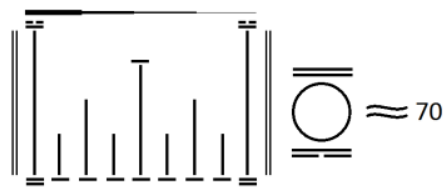

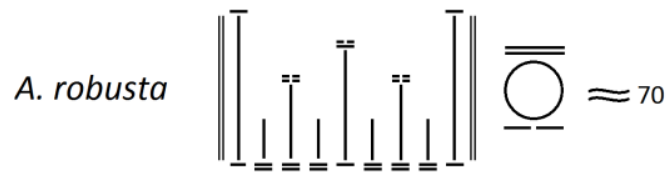

Fig. 12: Esquemas Vasculares (EV) obtidos para as espécies de Allagoptera (Arecaceae). 


\section{Referências bibliográficas}

Afonso, A. S., Medeiros, A., Nunes, C. S., Rodrigues, G., Nunes, R., Tavares, L. F., Conde, M. 2007. Florística da vegetação arbustiva aberta na Restinga da Marambaia - RJ. Revista Brasileira de Biociências, 5(2):450-452.

Alvarado, G., Jáuregui, D. 2011. Anatomía del raquis y la lámina foliar de Attalea butyracea (Mutis ex Lf) Wess. Boer y Attalea maripa (Aubl.) Mart. (Arecaceae, Arecoideae). Pittieria, 35:71-83.

Aoqui, M. 2012. Caracterização do óleo da polpa de macaúba (Acrocomia aculeata (Jacq.) Lodd. ex Mart.) e azeite de oliva (Olea europaea L.) virgem extra e seus efeitos sobre dislipidemia e outros parâmetros sanguíneos, tecido hepático e mutagênese em ratos Wistar. Campo Grande, Instituto de Biotecnologia, Departamento de Biotecnologia da Universidade Católica Dom Bosco. 143 p. Dissertação de Mestrado.

Appezzato-da-Glória, B., Carmello-Guerreiro, S. M. 2009. Anatomia Vegetal. Minas Gerais: Editora UFV.

Arduin, M., Krauss, J. E. 1997. Manual básico de técnicas em anatomia vegetal. Rio de Janeiro: Edur.

Balick M. J. 1988. The palm-tree of life: biology, utilization and conservation. New York: The New York Botanical Garden.

Barfod, A. 1988. Leaf anatomy and its taxonomic significance in phytelephantoid palms (Arecaceae). Nordic Journal of Botany, 8(4):341-348.

Batagin-Piotto, K. D., Almeida, C. V. D., Piotto, F. A., Almeida, M. D. 2012. Anatomical analysis of peach palm (Bactris gasipaes) leaves cultivated in vitro, ex vitro and in vivo. Brazilian Journal of Botany, 35(1):71-78.

Blackmore, S., Stafford, P., Persson, V. 1995. Palynology and systematics of Ranunculiflorae. In: Systematics and Evolution of the Ranunculiflorae. Springer Vienna. p. 71-82.

Carvalho, J. M., Maia, G. A., Sousa, P. H. M., Junior, G. A. M. 2006. Água-de-coco: propriedades nutricionais, funcionais e processamento. Semina: Ciências Agrárias, 27(3):437-452.

Chase, M. W. 2004. Monocot relationships: an overview. American Journal of Botany, 91(10):16451655. 
Craene, L. P. R. 2002. Floral development and anatomy of Pentadiplandra (Pentadiplandraceae): a key genus in the identification of floral morphological trends in the core Brassicales. Canadian Journal of Botany, 80(5):443-459.

Cutler, D. F., Botha, C. E. J., Stevenson, D. W. 2008. Plant anatomy: an applied approach. Oxford: Blackwell.

d'Almeida, J. R. M., Aquino, R. C. M. P., Monteiro, S. N. 2006. Tensile mechanical properties, morphological aspects and chemical characterization of piassava (Attalea funifera) fibers. Composites Part A: Applied Science and Manufacturing, 37(9):1473-1479.

de Melo, P. G. 2012. Produção e caracterização de biodieseis obtidos a partir da oleaginosa macaúba (Acrocomia aculeata). Uberlândia, Instituto de Química, Departamento de Química da Universidade Federal de Uberlândia. 93 p. Dissertação de Mestrado.

DeWalt, S. J., Maliakal, S. K., Denslow, J. S. 2003. Changes in vegetation structure and composition along a tropical forest chronosequence: implications for wildlife. Forest Ecology and Management, 182(1):139-151.

Dransfield, J., Uhl, N. W., Asmussen, C. B., Baker, W. J., Harley, M. M., Lewis, C. E. 2008. Genera Palmarum. Royal Botanic Gardens Kew, Kew UK.

Esau, K., Morretes, B. L. 1974. Anatomia das plantas com sementes. São Paulo: Edgard Blücher.

Fahn, A. 1982. Anatomía Vegetal. Pergamon Press.

Glassman, S. F. 1972. Systematic studies in the leaf anatomy of palm genus Syagrus. American Journal of Botany, 59(8):775-788.

Gomes, S. M., Borges, J. B. 2013. Fórmula vascular (FV) na descrição anatômica foliar de Syagrus glazioviana (Arecaceae). Anais do 640 Congresso Nacional de Botânica, Belo Horizonte. 10 a 15 de Novembro de 2013.

Gomes, S. M. A., Silva, E. A. M. D., Lombardi, J. A., Azevedo, A. A., Vale, F. H. A. 2005. Anatomia foliar como subsídio à taxonomia de Hippocrateoideae (Celastraceae) no sudeste do Brasil. Acta Botanica Brasilica, 19(4):945-961.

Gomes, S. M., Somavilla, N. S. D. N., Gomes-Bezerra, K. M., Miranda, S. D. C. D., Carvalho, P. S., Graciano-Ribeiro, D. 2009. Leaf anatomy of Myrtaceae species: contributions to the taxonomy and phylogeny. Acta Botanica Brasilica, 23(1):224-238.

Herr Jr, J. M. 1984. Embryology and taxonomy. In: Embryology of angiosperms. Springer Berlin Heidelberg. p. 647-696. 
Horn, J. W., Fisher, J. B., Tomlinson, P. B., Lewis, C. E., Laubengayer, K. 2009. Evolution of lamina anatomy in the palm family (Arecaceae). American journal of Botany, 96(8):1462-1486.

Johansen, D. A. 1940. Plant microtechnique. Mc Graw-Hill Book: New York.

Johnson, D. V. 1989. Present and potential economic usages of palms in arid and semi-arid areas. In: Plants for Arid Lands. Springer Netherlands.

Judd, W. S., Campbell, C. S., Kellog, E. A., Stevens, P. F., Donoghue, M. J. 2009. Sistemática vegetal: um enfoque filogenético. Editora Artmed: São Paulo.

Keating, R. C. 1984. Leaf histology and its contribution to relationships in the Myrtales. Annals of the Missouri Botanical Garden, 71:801-823.

Leitman, P., Henderson, A., Noblick, L., Martins, R. C. 2015. Arecaceae. In: Lista de espécies da flora do Brasil. Jardim Botânico do Rio de Janeiro. (http://floradobrasil.jbri.gov.br/jabot/floradobrasil/FB15662)

Lorenzi, H. 2010. Flora brasileira: Arecaceae (palmeiras). Instituto Plantarum de Estudos da Flora.

Lorenzi, H., Souza, H. M. D. 2010. Plantas ornamentais no Brasil: arbustivas, herbáceas e trepadeiras. Instituto Plantarum de Estudos da Flora.

Ma, O. S. W., Saunders, R. M. K. 2003. Comparative floral ontogeny of Maesa (Maesaceae), Aegiceras (Myrsinaceae) and Embelia (Myrsinaceae): taxonomic and phylogenetic implications. Plant Systematics and Evolution, 243(1-2):39-58.

Macía, M. J. 2004. Multiplicity in palm uses by the Huaorani of Amazonian Ecuador. Botanical Journal of the Linnean Society, 144(2):149-159.

Martins, R. C. 2012. A família Arecaceae (Palmae) no estado de Goiás: florística e etnobotânica. Brasília, Instituto de Ciências Biológicas, Departamento de Botânica da Universidade de Brasília. 297 p. Tese de Doutorado.

Martins, R. C., Filgueiras, T. S. 2010. Roteiro morfológico para coleta de palmeiras no Cerrado. Heringeriana, 4(1):51-59.

Martins, R. C., Filgueiras, T. S., Ulysses, P. 2012. Ethnobotany of Mauritia flexuosa (Arecaceae) in a maroon community in central Brazil. Economic botany, 66(1):91-98.

Martins, R. C., Filgueiras, T. D. S., Albuquerque, U. P. 2014. Use and diversity of palm (Arecaceae) resources in Central Western Brazil. The Scientific World Journal, 2014.

Martins, R. C., Filgueiras, T. S., Graciano-Ribeiro, D., Somavilla, N. S. 2015. A new species of Allagoptera (Arecaceae) from the Cerrado of central Brazil. Phytotaxa, 197(2):115-124. 
Mathew, A., Bhat, K. M. 1997. Anatomical diversity of Indian rattan palms (Calamoideae) in relation to biogeography and systematics. Botanical Journal of the Linnean Society, 125(1):71-86.

McElhinny, C., Gibbons, P., Brack, C., Bauhus, J. 2005. Forest and woodland stand structural complexity: its definition and measurement. Forest Ecology and Management, 218(1):1-24.

Neto, J. A. A., Júnior, A. W. 2002. Parâmetros fitossociológicos de um Cerrado no Parque Nacional da Serra do Cipó, MG. Revista Árvore, 26(5):645-648.

Menezes, L. D., Araujo, D. D. 2000. Variação da biomassa aérea de Allagoptera arenaria (Gomes) O. Kuntze (Arecaceae) em uma comunidade arbustiva de Palmae na Restinga de Marambaia, RJ. Revista Brasileira de Biologia, 60(1):147-157.

Millán, B., Kahn, F. 2010. Characterization of leaf anatomy in species of Astrocaryum and Hexopetion (Arecaceae). Revista Peruana de Biología, 17(1):81-94.

Mollet, M., Herzog, F., Behi, Y. E. N., Farah, Z. 2000. Sustainable exploitation of Borassus aethiopum, Elaeis guianeensis and Raphia hookeri for the Extraction of Palm Wine in Côte D'Ivoire. Environment, Development and Sustainability, 2(1):45-59.

Moraes, M. 1993. Allagoptera brevicalyx (Palmae), A new species from Bahia, Brazil. Brittonia, 45(1):2124.

Moraes, M. 1996. Allagoptera (Palmae). Flora Neotropica, 73:1-34.

Muñiz-Miret, N., Vamos, R., Hiraoka, M., Montagnini, F., Mendelsohn, R. O. 1996. The economic value of managing the açaí palm (Euterpe oleracea Mart.) in the floodplains of the Amazon estuary, Pará, Brazil. Forest Ecology and Management, 87(1):163-173.

Noblick, L. R. 2013. Leaflet anatomy verifies relationships within Syagrus (Arecaceae) and aids in identification. PhytoKeys, 26:75-99.

Noraini, T., Ruzi, A. R., Nurnida, M. K., Hajar, N. R. 2012. Systematic significance of leaf anatomy in Johannesteijsmannia H. E. Moore (Arecaceae). Pertanika Journal of Tropical Agricultural Science, 35(2):223-235.

Oliveira, D. M. T., Machado, S. R. 2009. Álbum didático de anatomia vegetal. Instituto de Ciências de Botucatu.

Plotkin, M. J., Balick, M. J. 1984. Medicinal uses of South American palms. Journal of Ethnopharmacology, 10(2):157-179.

Raven, P. H., Evert, R. F., Eichhorn, S. E. 2007. Biologia Vegetal. Sétima Edição. Editora Guanabara Koogan: Rio de Janeiro. 
Rolim, S. G., Ivanauskas, N. M., Rodrigues, R. R., Nascimento, M. T., Gomes, J. M. L., Folli, D. A., Couto, H. D. 2006. Composição florística do estrato arbóreo da floresta estacional semidecidual na planície aluvial do rio Doce, Linhares, ES, Brasil. Acta Botânica Brasilica, 20(3):549-561.

Rudall, P. J., Abranson, K., Dransfield, J., Baker, W. 2003. Floral anatomy in Dypsis (Arecaceae-Areceae):

a case of complex synorganization and stamen reduction. Botanical Journal of the Linnean Society, 143(2):115-133.

Sampaio, M. B. 2012. Ecologia, manejo e conservação do buriti (Mauritia flexuosa, Arecaceae) nos brejos do Brasil Central. Campinas, Instituto de Biologia, Departamento de Botânica da UNICAMP. Tese de Doutorado.

Sanders, R. W. 1987. Taxonomic significance of chromosome observations in Caribbean species of Lantana (Verbenaceae). American Journal of Botany, 74(6):914-920.

Sanín, M. J., Galeano, G. 2011. A revision of the Andean wax palms. Phytotaxa, 34:1-64.

Santiago, E. J. A., Pinto, J. E. B. P., Castro, E. M., Lameira, O. A., Conceição, H. E. O. 2001. Aspectos da anatomia foliar da pimenta-longa (Piper hispidinervium C. DC.) sob diferentes condições de luminosidade. Ciências agrotécnicas, 25(5):1035-1042.

Seubert, E. 1996a. Root anatomy of palms II. Calamoideae. Feddes Repertorium, 107(1-2):43-59.

Seubert, E. 1996b. Root anatomy of palms III. Ceroxyloideae, Nypoideae, Phytelephantoideae. Feddes Repertorium, 107(7):597-619.

Seubert, E. 1997. Root anatomy of palms. I. Coryphoideae. Flora, 192:81-103.

Seubert, E. 1998a. Root anatomy of palms IV. Arecoideae, part 1, General remarks and descriptions on the roots. Feddes Repertorium, 109(1-2):89-127.

Seubert, E. 1998b. Root anatomy of palms IV. Arecoideae, part 2 systematic implications. Feddes Repertorium, 109(3-4):231-247.

Silva, A. L. H. D. 2012. Anatomia do colmo e lâmina foliar de espécies de Paspalum L.(Poaceae: Panicoideae: Paniceae): novos caracteres taxonômicos e proposta de uma fórmula vascular para representação dos feixes vasculares da lâmina foliar. Brasília, Instituto de Ciências Biológicas, Departamento de Botânica da Universidade de Brasília. 86 p. Dissertação de Mestrado.

Silva, R. J. F., Potiguara, R. C. D. V. 2008. Aplicações taxonômicas da anatomia foliar de espécies amazônicas de Oenocarpus Mart.(Arecaceae). Acta Botanica Brasilica, 22(4):999-1014.

Sosnowska, J., Balslev, H. 2008. American palms used for medicine, in the ethnobotanical and pharmacological publications. Revista Peruana de Biología, 15:143-146.

Souza, V. C., Lorenzi, H. 2012. Botânica sistemática. Editora Plantarum: São Paulo. 
Tomlinson, P. B. 1961. Anatomy of the monocotyledons. II. Palmae. Clarendon Press: Oxford University Press.

Tomlinson, P. B., Horn, J. W., Fisher, J. B. 2011. The anatomy of palms. Arecaceae - Palmae. USA: Oxford University Press.

Türpe, A. M. 1967. Histotaxonomía de las especies argentinas del género Paspalum. Lilloa, 32:35-299.

Uhl, N. W., Moore, H. E. 1980. Androecial development in six polyandrous genera representing five major groups of palms. Annals of Botany, 45(1):57-75.

Zambrana, N. Y. P., Byg, A., Svenning, J. C., Moraes, M., Grandez, C., Balslev, H. 2007. Diversity of palm uses in the Western Amazon. Biodiversity and Conservation, 16(10):2771-2787. 


\section{Capítulo II}

Filogenia de Allagoptera Nees (Arecaceae) com base em dados morfoanatômicos 
Arecaceae (= Palmae; classe Liliopsida) é uma família monofilética pertencente à ordem Arecales. O grupo é constituído por cinco subfamílias, sendo Arecoideae a maior e mais diversificada. Dentro de Arecoideae gêneros de relevância econômica se destacam, como Elaeis, Cocos, Allagoptera, Attalea e Syagrus. Contudo, as relações de parentesco entre tribos, subtribos e gêneros de Arecoideae ainda permanecem incertas. Para Allagoptera, poucos estudos foram realizados, e a inclusão de duas espécies novas no gênero ( $A$. caudescens e $A$. robusta) torna necessária a realização de uma análise filogenética do grupo. Objetivou-se aqui traçar uma filogenia com base nos dados anatômicos observados para as espécies de Allagoptera (ver capítulo I), utilizando a espécie Phytelephas macrocarpa como grupo externo. A análise filogenética foi realizada no software PAST e alguns dados morfológicos das espécies, extraídos da literatura, também foram incluídos no estudo. As espécies mais basais da filogenia foram $A$. arenaria e $A$. caudescens, tendo esta última se diferenciado das demais por um grupo de nove caracteres morfoanatômicos. As relações filogenéticas entre as outras quatro espécies não puderam ser bem esclarecidas devido à baixa resolução (bootstrap) obtida, no entanto, parece claro que elas constituem um grupo mais derivado e, possivelmente, monofilético. O gênero provavelmente se diferenciou de outro gênero de Arecaceae em áreas litorâneas do Brasil, se diversificando em outras espécies à medida que começou a colonizar vegetações mais fechadas e ambientes mais distantes da costa. A elevada plasticidade fenotípica observada em espécies com ampla distribuição pelo território nacional, como A. campestris, aliada à baixa eficiência dos métodos morfoanatômicos em distinguir esta das demais espécies derivadas, levantam hipóteses sobre a existência de outras espécies ou subespécies dentro do gênero.

Palavras-chave: Attaleinae, parentesco, variabilidade morfológica, anatomia. 


\section{$A_{\text {bstract }}$}

Arecaceae (= Palmae; Liliopsida class) is a monophyletic family belonging to the order Arecales. The group is composed by five subfamilies, being Arecoideae the greater and most diversified. In Arecoideae genera of economic relevance stand out, such as Elaeis, Cocos, Allagoptera, Attalea and Syagrus. However, the phylogenetic relationships between tribes, subtribes and genera of Arecoideae still remain uncertain. For Allagoptera, few studies were performed, and the inclusion of two new species on the genus ( $A$. caudescens and $A$. robusta) makes necessary the achievement of a phylogenetic analysis of the group. We objectified here to delineate a phylogeny based on the anatomical data observed for the Allagoptera species (see chapther I), using the specie Phytelephas macrocarpa as outgroup. The phylogenetic analysis was performed on the software PAST and some morphological data of the species, extracted from the literature, were also included on the analysis. The most basal species of the phylogeny were $A$. arenaria and $A$. caudescens, the latter being distinguished from the others by a group of nine morphoanatomical characters. The phylogenetic relationships between the four other species could not be well enlightened due to the low resolution (bootstrap) obtained, however, it seems clear that they constitute a group more derivative and, possibly, monophyletic. The genus probably was differentiated from other Arecaceae genus in coastal areas of Brazil, diversifying in other species as it started to conquer closer vegetations and farther environments to the seashore. The high phenotypic plasticity observed in species with wide distribution on the national territory, such as A. campestris, together with the low efficiency of the morphoanatomical methods in distinguishing this of the remaining derivative species, raise hipothesis about the existence of other species or subspecies inside the genus.

Key-words: Attaleinae, relationship, morphological variability, anatomy. 
Desde os tempos mais remotos da humanidade a organização e a sistematização desempenham papel essencial ao homem, auxiliando-o na estruturação e na divisão de tarefas na sociedade (Wilson, 2012). Contudo, ao longo da história, surgiram dificuldades na análise dos organismos vivos devido à carência de um sistema de organização geral que classificasse os seres dos mais simples aos mais complexos.

O filósofo Aristóteles foi o primeiro a apresentar um sistema de classificação dos organismos animais - scala naturae -, que levava em consideração o tipo de reprodução e a temperatura corporal (Ariza \& Martins, 2010). Contudo, este sistema de classificação ainda não era completo e não levava em conta a evolução biológica. Muitos séculos depois, tendo encerrado o período de Idade Média na Europa, os irmãos Johann e Gaspar Bauhin já faziam uso de um sistema de classificação bastante eficiente, que posteriormente foi aperfeiçoado e popularizado pelo cientista sueco Carl Linnaeus (Jarvis \& Knees, 1988). Tratava-se do sistema de classificação binomial dos organismos, que revolucionou a ciência e tornou possível um método sintético e conveniente para a classificação biológica (Raven et al., 2007). Porém, apenas no século XIX Darwin tornou possível a integração da evolução biológica nos sistemas de classificação, o que possibilitou analisar os organismos como seres em constante adaptação ao meio em que estão inseridos (Judd et al., 2009).

Entende-se por taxonomia a teoria e a prática da delimitação e da classificação dos tipos de organismos (Simpson, 1961). A sistemática é o estudo científico dos tipos e da diversidade dos organismos, e de todo e qualquer parentesco entre eles (Mayr \& Ashlock, 1969). Dessa maneira, a taxonomia busca simplesmente a identificação e a descrição, enquanto a sitemática procura analisar as relações entre os organismos descritos pela taxonomia. De certa forma, a sistemática pode remontar a história evolutiva de diferentes grupos de organismos, sendo nesse caso denominada filogenia (Raven et al., 2007).

De acordo com Souza \& Lorenzi (2012), os primeiros sistemas filogenéticos foram surgindo após Darwin ter publicado suas ideias sobre evolução em sua obra clássica "Origem das Espécies". No entanto, apenas a partir da segunda metade do século XX, com a popularização dos trabalhos do alemão Willi Hennig em cladística, estas ideias passaram a ser mais consolidadas (Schmitt, 2003). A aplicação de técnicas moleculares a partir do final do século XX também deu outro enfoque às análises filogenéticas, que até então eram feitas com base em caracteres morfológicos e anatômicos (Raven et al., 2007). 
No meio botânico, tais ideias começaram a ser aplicadas na década de 1980 com o sistema de classificação de Cronquist (Cronquist, 1981) e tomaram força na década de 1990 com o "Angiosperm Phylogeny Group" (APG, 1998), que se encontra em sua terceira atualização (APG III, 2009). Apesar do sistema elaborado por Cronquist (1981) ainda ser bastante utilizado nos dias atuais, vale ressaltar que este sistema é gradista, ao passo que o APG apresenta uma abordagem cladista, sendo mais aceito pela comunidade científica (Souza \& Lorenzi, 2012).

\section{Taxonomia de Arecaceae}

Arecaceae Bercht. \& J. Presl (Palmae) é a única família que compõe a ordem Arecales Bromhead. Embora esta ordem taxonômica seja claramente monofilética (Judd et al., 2009), as relações de parentesco com as outras monocotiledôneas ainda não são muito claras, ainda que alguns autores apontem um possível parentesco com as Commelinales Mirb. ex Bercht. \& J. Presl. (Dahlgren et al., 1985; Chase, 2004).

Na década de 1970, o estudo pioneiro sobre a filogenia de Arecaceae foi publicado (Moore, 1973). Nesse trabalho, as noções evolutivas existentes entre os diferentes gêneros das palmeiras foram primeiramente elucidadas por meio de um sistema de classificação. A ideia de que Arecaceae constitui uma família monofilética dentro do grupo das monocotiledôneas (Chase et al., 2000) cada vez mais temse consolidado. No entanto, as relações filogenéticas das tribos que compõem a família ainda são incertas (Asmussen et al., 2006).

As relações de parentesco entre os grupos que compõem a família têm sido reveladas por meio de alguns trabalhos (Asmussen \& Chase, 2001; Hahn, 2002; Baker et al., 2011). Está claro que Calamoideae Beilschm. e Nypoideae Griff. constituem grupos monofiléticos, sendo Calamoideae grupo irmão de todas as outras palmeiras (Asmussen et al., 2006). Arecoideae Burnett é grupo irmão de Ceroxyloideae Drude, e estes dois grupos juntos são irmãos de Coryphoideae Burnett (Asmussen et al., 2006; Baker et al., 2011). A Fig. 1 ilustra as relações de parentesco entre as subfamílias de Arecaceae. 


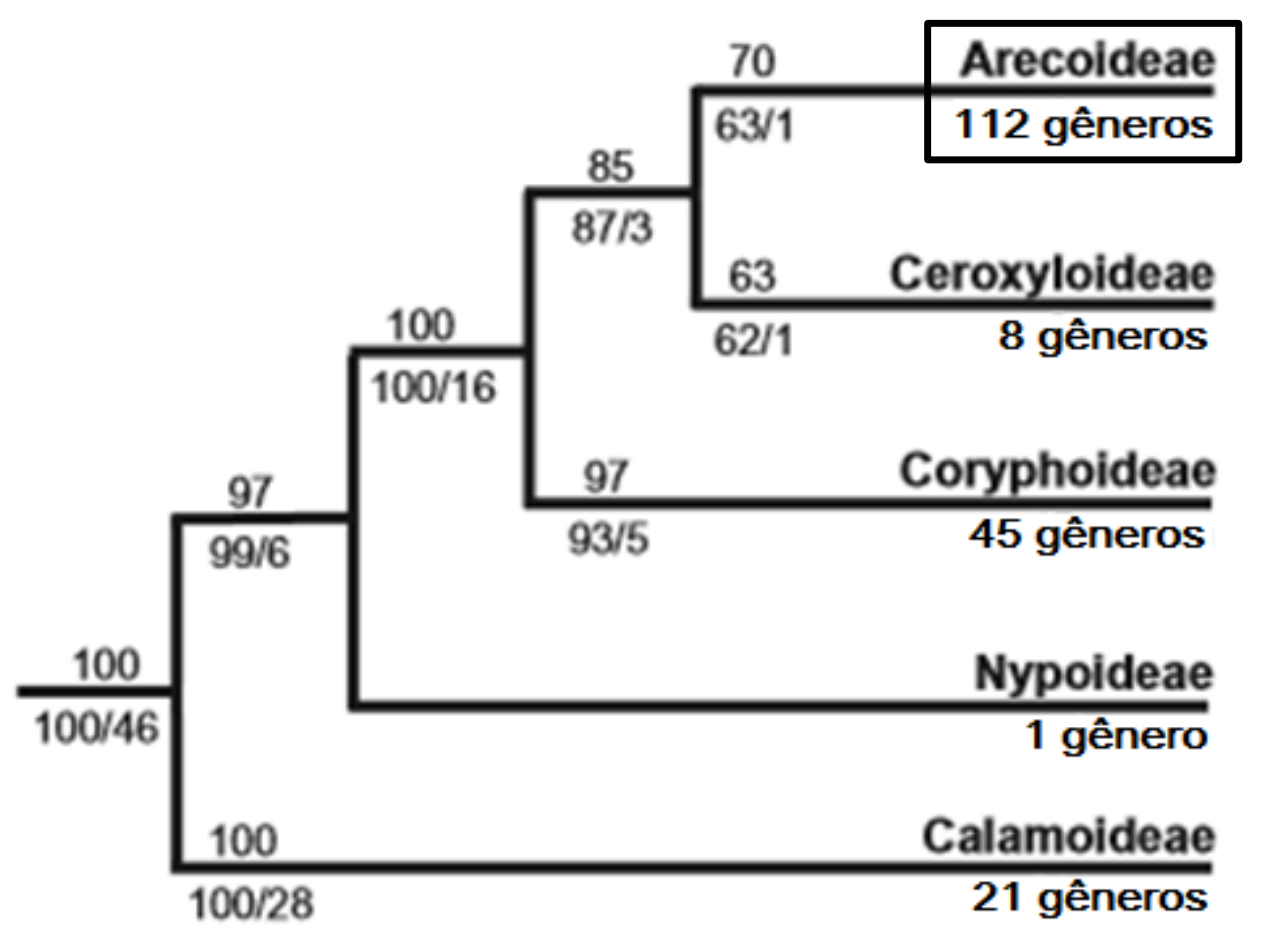

Fig. 1: Relações de parentesco entre as subfamílias de Arecaceae. Fonte: Asmussen et al., 2006.

As relações morfológicas e taxonômicas de muitos clados de Calamoideae Beilschm. ainda permanecem mal compreendidas (Baker et al., 2000). Embora claramente monofilética (Asmussen \& Chase, 2001), Arecoideae, que é a mais diversificada subfamília de Arecaceae, possui relativamente poucos caracteres informativos parcimoniosos, o que também torna a classificação do grupo precária (Asmussen et al., 2006).

Dentre as tribos que compõem Arecoideae, sabe-se que Geonomateae Luerss. é grupo irmão de Manicarieae J. Dransf., N. W. Uhl, Asmussen, W. J. Baker, M. M. Harley \& C. E. Lewis (Asmussen et al., 2006), enquanto Oranieae Becc. e Podococceae J. Dransf. \& N. W. Uhl, Sclerospermeae J. Dransf., N. W. Uhl, Asmussen, W. J. Baker, M. M. Harley \& C. E. Lewis estariam juntas em um mesmo clado (Baker et al., 2011). Segundo estes mesmos autores, Areceae Mart. é uma tribo que compreende alguns gêneros com posicionamento ainda incerto.

A tribo Cocoseae Mart. tem uma história filogenética ainda pouco estudada (Gunn, 2004; Dransfield et al., 2008), embora sua monofilia seja consenso (Hahn, 2002; Baker et al., 2011). O grupo é constituído por 18 gêneros, distribuídos em três subtribos: Attaleinae Drude, Bactridinae Drude e Elaeidinae Drude, que são monofiléticas entre si (Gunn, 2004). As relações filogenéticas entre as tribos e subtribos que compõem a subfamília Arecoideae são ilustradas na Fig. 2.

Podemos então observar que, apesar da ampla literatura sobre a filogenia de Arecaceae, ainda existem muitas lacunas no conhecimento, principalmente quanto às relações de parentesco entre 
gêneros e subtribos que constituem a família, havendo grande necessidade de estudos em especial para a subtribo Attaleinae (Tomlinson et al., 2011). Com efeito, para muitos gêneros do grupo, a monofilia ainda não foi testada (Dransfield et al., 2008).

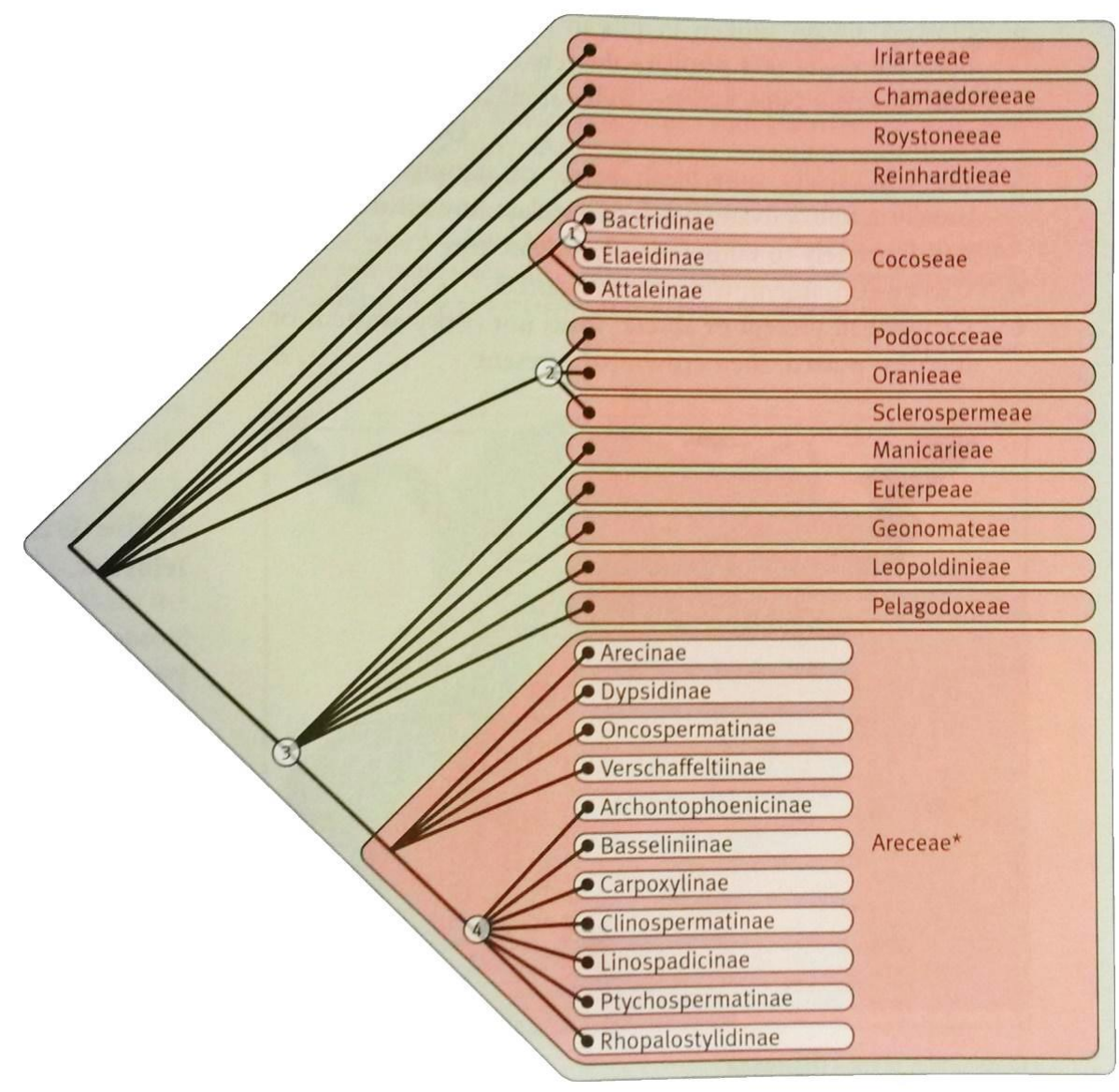

Fig. 2: Relações entre as subtribos e tribos da subfamília Arecoideae. Fonte: Dransfield et al., 2008.

\section{Taxonomia de Allagoptera Nees}

Allagoptera Nees é um gênero pertencente à subtribo Attaleinae, sendo claramente monofilético (Gunn, 2004). É grupo irmão do clado de Attalea Kunth, Lytocaryum Toledo e Syagrus Mart. (baixo suporte) e gênero irmão de Cocos L. e Attalea Kunth (baixo suporte; Hahn, 2002).

Historicamente, Allagoptera é um grupo taxonômico reconhecido desde 1821 (Nees von Esenbeck, 1821), porém as espécies que constituem o grupo passaram a fazer parte do gênero Diplothemium Martius (Martius, 1824 apud Moraes, 1996). Somente a partir de meados do século XX o gênero foi validado por Moore (Moore, 1962). Allagoptera pertencia à Butiinae, porém Dransfield et al. (2005) propuseram que os gêneros dessa subtribo fossem transferidos para Attaleinae e que Butiinae deixasse de existir. 
Quatro espécies (Allagoptera arenaria (Gomes) Kuntze, A. brevicalyx M. Moraes, A. campestris (Mart.) Kuntze e A. leucocalyx (Drude) Kuntze) foram reconhecidas na revisão taxonômica de Allagoptera (Moraes, 1996). Uma quinta espécie - A. caudescens (Mart.) Kuntze, anteriormente pertencente ao gênero Polyandrococos Barb. Rodr., foi listada por Dransfield et al. (2008) e Lorenzi (2010), totalizando cinco espécies, que ocorrem no Paraguai, na Bolívia e no Brasil. Uma sexta espécie, Allagoptera robusta R. C. Martins \& Filg., foi acrescentada à lista (Martins et al., 2015).

Embora alguns estudos contemplem as relações de parentesco com outros gêneros (Asmussen \& Chase, 2001; Hahn, 2002; Gunn, 2004), ainda é inexistente uma análise de parentesco entre as espécies de Allagoptera. Em sua revisão taxonômica, Moraes (1996) observou a existência de dois grupos de espécies: um formado por $A$. campestris, A. leucocalyx e A. arenaria e outro formado por uma única espécie, $A$. brevicalyx. Embora esta revisão taxonômica seja bastante ampla, ela não contempla a filogenia do gênero e não inclui as espécies até então desconhecidas $A$. caudescens e $A$. robusta. Dessa forma, as relações de parentesco entre as espécies de Allagoptera apresentam lacunas a esclarecer. 


\section{$\mathbf{H}_{\text {iptiteses }}$}

- Existe relação de parentesco entre as espécies de Allagoptera.

- Allagoptera campestris, A. leucocalyx e A. arenaria constituem um clado distinto do clado de Allagoptera brevicalyx. Esta hipótese busca contemplar o agrupamento proposto por Moraes (1996), que distinguiu A. brevicalyx do grupo formado por A. campestris, A. leucocalyx e A. arenaria.

\section{Objetivo geral}

- Analisar as relações filogenéticas entre as espécies de Allagoptera Nees com base em caracteres morfoanatômicos.

\section{Objetivos específicos}

- Analisar e considerar as relações de parentesco entre as espécies de Allagoptera Nees.

- Identificar quais caracteres são mais basais e quais são mais derivados dentro do gênero. 


\section{$\mathbf{M}_{\text {aterial e métodos }}$}

\section{Análise filogenética}

Os dados utilizados neste estudo foram os obtidos por meio da análise anatômica descrita no capítulo I dessa dissertação. Foram também acrescentados alguns caracteres morfológicos consultados na literatura (Uhl \& Dransfield, 1987; Moraes, 1996; Martins, 2012), de modo a dar uma consistência maior na análise. Os dados foram transformados em uma matriz de 0, 1 e 2 e posteriormente transferidos para o software PAST (PAleontological STatistics), onde foram processados 5 vezes, com 500 replicações, utilizando o método Heurístico NNI (Nearest Neighbour Interchange), com otimização de Fitch, e o cladograma de consenso estrito foi selecionado. Caracteres quantitativos foram primeiramente organizados em diferentes grupos e só então transformados em números.

A espécie Phytelephas macrocarpa Ruiz \& Pav. foi utilizada como grupo externo. Esta espécie foi selecionada por ser uma espécie nativa do Brasil e por já ter sido analisada em sua anatomia foliar (Tomlinson, 1961; Barfod, 1988; Tomlinson, 2011). Os caracteres anatômicos analisados para Allagoptera, mas que não foram encontrados na literatura sobre Phytelephas não foram descartados, tendo sido simplesmente marcados com um ponto de interrogação (?) para a análise no programa PAST.

Um total de 154 caracteres das seis espécies de Allagoptera e de Phytelephas macrocarpa foram analisados por meio do software PAST, sendo 106 caracteres anatômico-foliares e 48 morfológicos externos. Os diferentes caracteres utilizados para a realização da filogenia encontram-se relacionados na Tabela 1 em anexo.

Com base em dados da literatura (Moraes, 1996; Lorenzi, 2010; Leitman et al., 2015), um mapa com a distribuição das espécies foi delineado. A construção desse mapa visou correlacionar o ambiente onde as espécies ocorrem (Cerrado, Mata Atlântica ou Restinga) com sua posição filogenética (espécie mais basal ou espécie mais derivada) e com sua distribuição geográfica (espécie mais generalista ou espécie mais especialista). 


\section{$\mathbf{R}_{\text {esultados }}$}

A filogenia obtida a partir da análise dos 154 caracteres morfoanatômicos revelou que Allagoptera caudescens foi a espécie que primeiramente se diferenciou no gênero (bootstrap = 100), sendo sucedida por $A$. arenaria (bootstrap =98). Estas duas espécies divergiram de forma independente das demais e entre si, formando três grupos: um constituído por $A$. caudescens, outro formado por $A$. arenaria e outro constituído pelas demais espécies, aparentemente monofiléticas. As relações entre as demais espécies ficaram obscurecidas pelos baixos valores obtidos para o bootstrap, porém parece claro que essas espécies são as mais derivadas do gênero (Fig. 3). Allagoptera campestris, A. leucocalyx e A. robusta constituem um clado distinto do clado de Allagoptera brevicalyx.

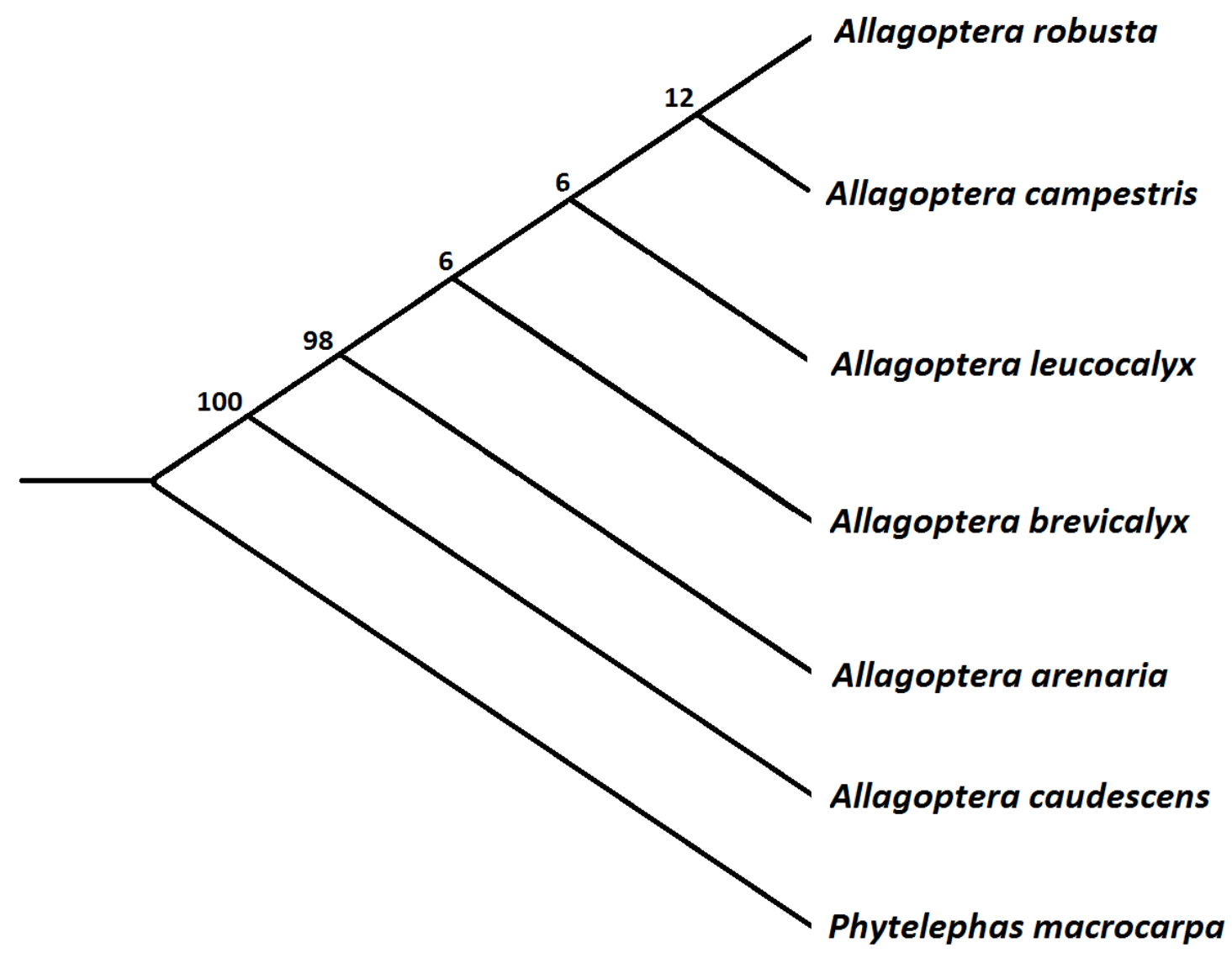

Fig. 3. Árvore filogenética de Allagoptera Nees (Arecaceae), com base em 154 caracteres morfoanatômicos. Valores de bootstrap indicados nos nós. 
Allagoptera caudescens distinguiu-se das demais do gênero por ter apresentado uma epiderme sem papilas adaxialmente, células epidérmicas comuns com contorno tanto regular quanto irregular abaxialmente, hipoderme adaxial menos espessa que abaxial, células da hipoderme adaxial ovoides ou circulares em secção transversal, fibras situadas internamente à hipoderme e ausência de grupos de fibras marginais. Morfologicamente, a espécie distinguiu-se por seu porte arbóreo e pelos seus segmentos inseridos no mesmo plano da raque foliar.

Allagoptera arenaria diferenciou-se por apresentar células da epiderme adaxial exclusivamente retangulares ou hexagonais em vista paradérmica, relação largura:altura das células comuns da epiderme adaxial sempre maior que 2:1 (células bem mais largas que altas), estômatos distribuídos em três ou mais fileiras estomáticas, células hipodérmicas abaxiais exclusivamente circulares em secção transversal um único vaso de metaxilema e grupos de fibras exclusivamente elíptico deitados. Em termos morfológicos, esta espécie distinguiu-se por sua flor pistilada séssil, sépalas da flor estaminada livres, sépalas e pétalas da flor pistilada com tricomas e mais de uma semente por fruto.

Allagoptera brevicalyx, A. campestris, A. leucocalyx e A. robusta formaram um grupo monofilético com baixo suporte. A monofilia do grupo foi sustentada pelo formato quadrangular, retangular ou ovoide das células da epiderme adaxial em seç̧ão transversal, relação largura:altura das células comuns da epiderme adaxial ligeiramente semelhante $(1: 2,1: 1$ ou 2:1) - ou com muitas variações na mesma lâmina -, estômatos distribuídos em uma ou duas fileiras estomáticas, células hipodérmicas abaxiais ovoides, circulares ou retangulares em seç̧ão transversal, um ou dois vasos de metaxilema no feixe vascular principal e grupos de fibras com formato obtriangular ou elíptico deitado.

Ausência de depressões na face abaxial e protoxilema localizado tanto no centro da lâmina quanto próximo a face adaxial são caracteres que delimitam a monofilia - com baixo suporte - de Allagoptera campestris, A. leucocalyx e A. robusta. O outro grupo, constituído por Allagoptera arenaria e A. brevicalyx, é caracterizado por depressões na face abaxial e pelo protoxilema voltado apenas para a face adaxial da lâmina. Os caracteres morfológicos distinguem esses dois grupos mais visivelmente: Allagoptera arenaria e $A$. brevicalyx são ambas espécies de Restinga, com raque curta e relativamente poucos segmentos de cada lado da folha.

Allagoptera campestris e $A$. robusta constituem um grupo monofilético também com baixo suporte, sendo a monofilia do grupo sustentada pela ocorrência do complexo estomático tanto na região costal quanto na região intercostal da lâmina, células buliformes tão largas quanto altas, mesofilo homogêneo e grupos de fibras abundantes ao longo da lâmina foliar. As três demais espécies Allagoptera arenaria, A. brevicalyx e A. leucocalyx - apresentaram um complexo estomático apenas na região costal, células buliformes mais largas que altas, mesofilo dorsiventral (clássico ou gradativo) e grupos de fibras não tão abundantes. Morfologicamente, essas espécies possuem um porte maior que Allagoptera campestris e A. robusta e apresentam ramenta na face abaxial de seus segmentos. 
O mapa obtido indicou que as espécies de Restinga - Allagoptera arenaria e A. brevicalyx - e a espécie de Mata Atlântica - $A$. caudescens - são restritas a regiões costeiras, enquanto as espécies de Cerrado - A. campestris, A. leucocalyx e A. robusta - encontram-se distribuídas exclusivamente pelo interior do território brasileiro (Fig. 4). A. brevicalyx e A. robusta apresentaram-se restritas às regiões do Recôncavo Baiano e do Planalto Central, respectivamente, enquanto A. campestris e A. leucocalyx foram as espécies mais generalistas, com distribuição por toda a extensão do Cerrado brasileiro.

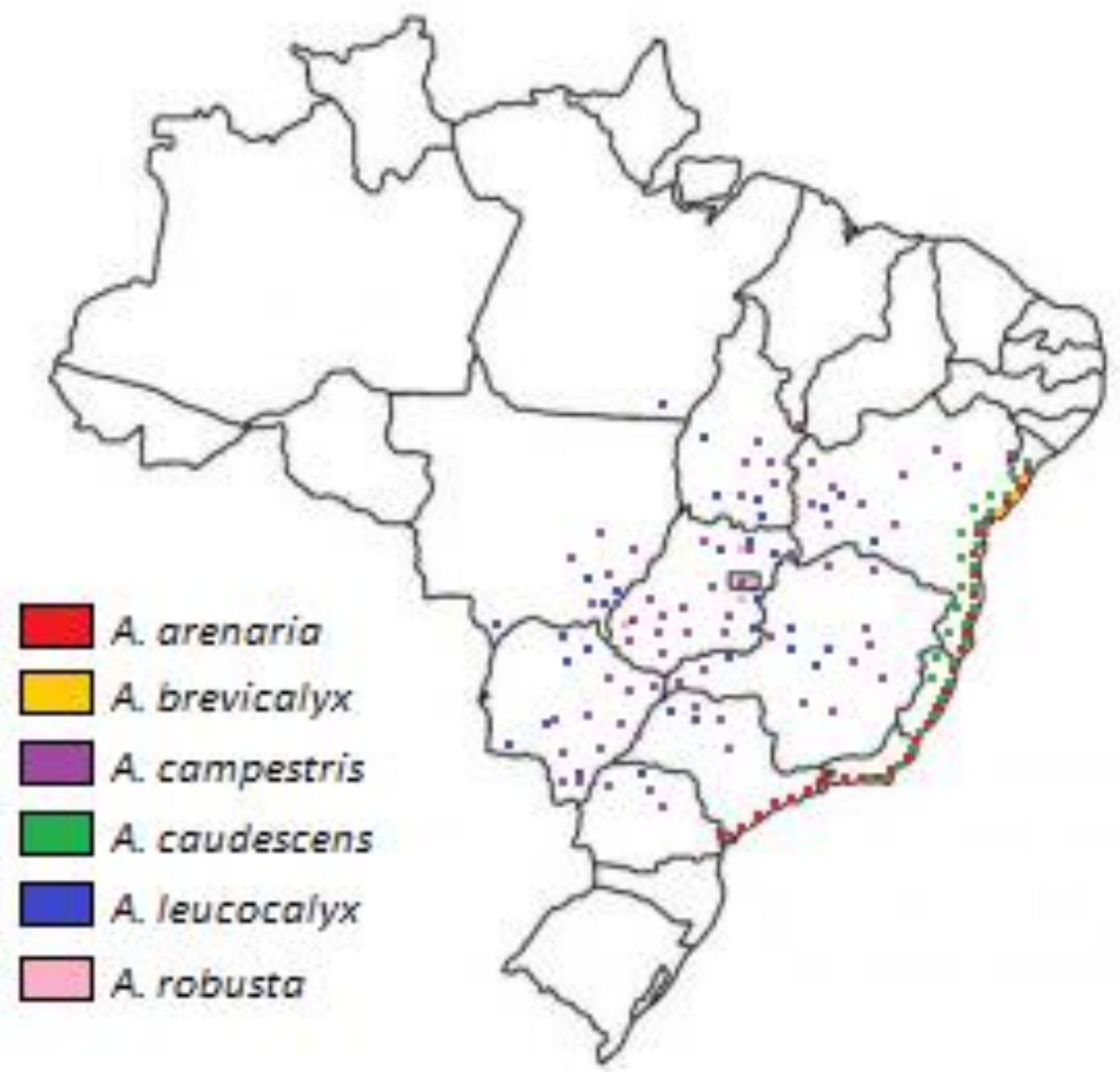

Fig. 4. Distribuição geográfica de Allagoptera Nees (Arecaceae) pelo território brasileiro. Fonte: Lorenzi, 2010; Leitman et al., 2015. 
A partir dos resultados obtidos, podemos inferir que Allagoptera caudescens é a espécie que mais diverge das demais espécies do gênero. Esta constatação está de acordo com a literatura, uma vez que $A$. caudescens apresenta uma série de características - principalmente na sua morfologia externa consideradas exceção para o gênero como um todo, como planta de mais de três metros de altura, segmentos organizados no mesmo plano da raque foliar, inflorescência com mais de 1,0 metro de comprimento e número de estames superior a 60 (Uhl \& Dransfield, 1987; Moraes, 1996, sobre Polyandrococos caudescens Barb. Rodr.; Lorenzi, 2010).

As análises também apontaram que $A$. arenaria não está incluída na monofilia de $A$. brevicalyx, A. campestris, A. leucocalyx e A. robusta. Em um estudo taxonômico do gênero, Moraes (1996) postulou que este é constituído por dois grupos de espécies, um formado por Allagoptera arenaria, A. campestris e $A$. leucocalyx, que seriam distintos de $A$. brevicalyx. Nesse sentido, nossos resultados corroboram em parte esta hipótese, pois verificou-se que $A$. arenaria seria a espécie distinta das demais, enquanto $A$. brevicalyx, A. campestris e A. leucocalyx formariam um clado, juntamente com A. robusta. Cabe lembrar que $A$. caudescens e $A$. robusta são espécies que só passaram a compor o gênero a partir do trabalho de Dransfield et al. (2005) e Martins et al. (2015), respectivamente, não tendo sido, portanto, abordadas no trabalho de Moraes (1996).

O clado formado por A. brevicalyx, A. campestris, A. leucocalyx e A. robusta não tiveram uma resolução (bootstrap) satisfatória na árvore, não sendo, portanto, separadas de maneira satisfatória. Em sua comparação morfoanatômica entre A. campestris, A. leucocalyx e A. robusta, Martins et al. (2015) verificaram um grande número de caracteres compartilhados pelas três espécies, sendo a distinção entre elas muito sutil. É possível que $A$. brevicalyx também tenha muitos caracteres em comum com este grupo de plantas, uma vez que a espécie pode ser facilmente confundida com $A$. campestris nos ambientes em que as duas ocorrem juntas (Moraes, 1993).

Para A. campestris, Martins (2012) observou que o reconhecimento dessa espécie não se mostrou eficaz por meio da contagem do número de estames, que foi um método proposto por Moraes (1996) para o gênero Allagoptera. Assim como A. leucocalyx, esta espécie encontra-se distribuída por amplas extensões do Cerrado brasileiro, estando possivelmente sujeita a uma elevada variabilidade morfológica (Fig. 4) Diante disso, nossos resultados parecem razoáveis ao apontar A. robusta como sendo a espécie mais derivada, formando um grupo monofilético com $A$. campestris. A variabilidade 
morfológica dessa espécie ainda deve ser avaliada mais cautelosamente para que se possa saber se o gênero Allagoptera apresenta outras espécies ou subespécies.

As espécies nativas do bioma Cerrado - A. campestris, $A$. leucocalyx e A. robusta - apareceram como as mais derivadas dentro da monofilia, enquanto a espécie de Restinga $A$. brevicalyx foi apontada como a mais basal, estando próxima a $A$. arenaria e $A$. caudescens, espécies que também habitam zonas litorâneas (Fig. 4). Uma possível hipótese é a de que o gênero Allagoptera tenha se originado nas regiões litorâneas do Brasil, de onde se diversificou à medida que passou a conquistar ambientes mais fechados, como os Cerrados do Brasil Central e os Gran Chacos e Llanos de Moxos bolivianos, paraguaios e argentinos.

Em suas observações, Moraes (1996) constatou que, embora diferente das demais espécies, $A$. brevicalyx compartilha alguns poucos caracteres morfológicos com A. campestris. Nossas análises mostraram que a espécie se assemelha mais a $A$. arenaria. No entanto, devido à baixa resolução obtida neste clado, mais estudos devem ser realizados, de modo a verificar o parentesco entre $A$. brevicalyx e as demais espécies do gênero.

Embora tenham formado grupos distintos, $A$. arenaria e $A$. caudescens compartilharam alguns poucos caracteres, como células comuns da epiderme adaxial mais largas que altas, células hipodérmicas abaxiais exclusivamente circulares em secção transversal, um único vaso de metaxilema no feixe vascular principal e uma flor pistilada séssil. Apesar dessas características em comum, aspectos morfoanatômicos do caule (múltiplo em A. arenaria e solitário em A. caudescens), da folha (levemente sinuosa em $A$. arenaria e acentuadamente sinuosa abaxialmente em $A$. caudescens) e da flor (duas brácteas pedunculares em $A$. arenaria e uma única em $A$. caudescens) separam essas duas espécies (Lorenzi, 2010; Tomlinson et al., 2011). 


\section{$\mathrm{C}_{\text {onclusăo }}$}

Os resultados apresentados nesse estudo ressaltam a importância da utilização de características morfoanatômicas para a construção de chaves de identificação e filogenias, evidenciando que, quando associada à anatomia, a morfologia torna-se uma ferramenta poderosa. Contudo, embora os dados morfoanatômicos tenham desempenhado importante papel para a distinção das espécies de Allagoptera, eles não foram isoladamente resolutivos para a filogenia, sendo possível apenas afirmar que as espécies litorâneas $A$. caudescens e $A$. arenaria surgiram primeiro na evolução do gênero, que foi se interiorizando pelas vegetações mais fechadas do continente sul-americano. Allagoptera deve ser investigada futuramente sob outros aspectos - embriológicos, genéticos, palinológicos, citológicos, entre outros -, de modo a se obter uma árvore filogenética mais precisa. A variabilidade morfológica também deve ser levada em conta nas análises, sobretudo para espécies que apresentam ampla distribuição geográfica, como $A$. campestris e $A$. leucocalyx. As estratégias de defesa das espécies devem ser investigadas por estudos futuros, tendo em vista a abundância de taninos na lâmina foliar. A sugestão de padronização da terminologia "célula buliforme" à família Arecaceae, bem como os novos caracteres observados nesse estudo (mesofilo dorsiventral gradativo e cristas subsidiárias), visam contribuir e facilitar o estudo da Anatomia Vegetal. Semelhantemente, as Fórmulas e Esquemas Vasculares, que se apresentaram úteis para a descrição e distinção das espécies do gênero, também apresentam este propósito. 


\section{$\mathbf{R}_{\text {eferencias b bibliograficas }}$}

APG. 1998. An ordinal classification for the families of flowering plants. Annals of the Missouri Botanical Garden, 531-553.

APG III. 2009. An update of the Angiosperm Phylogeny Group classification for the orders and families of flowering plants: APG III. Botanical Journal of the Linnean Society 141:399-436.

Ariza, F. V., Martins, L. A. C. P. 2010. A Scala Naturae de Aristóteles na Obra De Generatione Animalium. Filosofia e História da Biologia 5(1):21-34.

Asmussen, C. B., Chase, M. W. 2001. Coding and noncoding plastid DNA in palm systematics. American Journal of Botany 88(6):1103-1117.

Asmussen, C. B., Dransfield, J., Deickmann, V., Barfod, A. S., Pintaud, J. C., Baker, W. J. 2006. A new subfamily classification of the palm family (Arecaceae): evidence from plastid DNA phylogeny. Botanical Journal of the Linnean Society 151(1):15-38.

Baker, W. J., Dransfield, J., Hedderson, T. A. 2000. Phylogeny, character evolution, and a new classification of the calamoid palms. Systematic Botany, 25(2):297-322.

Baker, W. J., Norup, M. V., Clarkson, J. J., Couvreur, T. L., Dowe, J. L., Lewis, C. E., Pintaud, J. C., Savolainen, V., Wilmot, T., Chase, M. W. 2011. Phylogenetic relationships among arecoid palms (Arecaceae: Arecoideae). Annals of Botany, 108(8):1417-1432.

Barfod, A. 1988. Leaf anatomy and its taxonomic significance in phytelephantoid palms (Arecaceae). Nordic Journal of Botany, 8(4):341-348.

Chase, M. W., De Bruijn, A. Y., Cox, A. V., Reeves, G., Rudall, P. J., Johnson, M. A., Eguiarte, L. E. 2000. Phylogenetics of Asphodelaceae (Asparagales): an analysis of plastid rbcL and trnL-F DNA sequences. Annals of Botany, 86(5):935-951.

Chase, M. W. 2004. Monocot relationships: an overview. American Journal of Botany, 91(10):16451655.

Cronquist, A. 1981. An Integrated System of Classification of Flowering Plants. Columbia University Press, New York, New York, USA.

Dahlgren, R. M. T., Clifford, H. T., Yeo, P. F. 1985. The families of the monocotyledons. Structure, evolution, and taxonomy. Brittonia, 37:231-3. 
Dransfield, J., Uhl, N. W., Asmussen, C. B., Baker, W. J., Harley, M. M., Lewis, C. E. 2005. A new phylogenetic classification of the palm family, Arecaceae. Kew Bulletin, 60:559-569.

Dransfield, J., Uhl, N. W., Asmussen, C. B., Baker, W. J., Harley, M. M., Lewis, C. E. 2008. Genera Palmarum. Royal Botanic Gardens Kew, Kew UK.

Gunn, B. F. 2004. The phylogeny of the Cocoeae (Arecaceae) with emphasis on Cocos nucifera. Annals of the Missouri Botanical Garden, 91(3):505-522.

Hahn, W. J. 2002. A molecular phylogenetic study of the Palmae (Arecaceae) based on atpB, rbcL, and 18S nrDNA sequences. Systematic Biology, 51(1):92-112.

Jarvis, C. E., Knees, S. G. 1988. Linnean names in the genus Athamanta L. (Umbelliferae: Apioideae) and their typification. Taxon, 37(2):472-477.

Judd, W. S., Campbell, C. S., Kellog, E. A., Stevens, P. F., Donoghue, M. J. 2009. Sistemática Vegetal: Um Enfoque Filogenético. Terceira Edição. Editora Artmed: São Paulo.

Leitman, P., Henderson, A., Noblick, L., Martins, R. C. 2015. Arecaceae in Lista de Espécies da Flora do Brasil. Jardim Botânico do Rio de Janeiro. (http://floradobrasil.jbrj.gov.br/jabot/floradobrasil/FB15662)

Lorenzi, H. 2010. Flora Brasileira: Arecaceae (Palmeiras). Instituto Plantarum de Estudos da Flora.

Mayr, E., Ashlock, P. D. 1969. Principles of systematic zoology.

Martins, R. C. 2012. A família Arecaceae (Palmae) no estado de Goiás: florística e etnobotânica. Brasília, Instituto de Ciências Biológicas, Departamento de Botânica da Universidade de Brasília. 297 p. Tese de Doutorado.

Martins, R. C., Filgueiras, T. S., Graciano-Ribeiro, D., Somavilla, N. S. 2015. A new species of Allagoptera (Arecaceae) from the Cerrado of central Brazil. Phytotaxa, 197(2):115-124.

Moore, H. E. 1962. Allagoptera and Diplothemium. Principes, 6:37-39.

Moore, H. E. 1973. The major groups of palms and their distribution. Gentes Herb 11, 27-141.

Moraes, M. 1993. Allagoptera brevicalyx (Palmae), A new species from Bahia, Brazil. Brittonia, 45(1):2124.

Moraes, M. 1996. Allagoptera (Palmae). Flora Neotropica, 1-34.

Nees von Esenbeck, C. G. D. 1821. Beschluss der Nachrichten über die beiden brasilischen Reisenden die Herren Doctoren v. Spix und v. Martius. Flora 4:289-330.

Raven, P. H., Evert, R. F., Eichhorn, S. E. 2007. Biologia Vegetal. Sétima Edição. Editora Guanabara Koogan: Rio de Janeiro. 
Schmitt, M. 2003. Willi Hennig and the rise of cladistics. The New Panorama of Animal Evolution, 369379.

Simpson, G. G. 1961. Principles of animal taxonomy, 20. Columbia University Press.

Souza, V. C., Lorenzi, H. 2012. Botânica Sistemática: Guia ilustrado para identificação das famílias nativas e exóticas no Brasil, baseado em APG III. Nova Odessa, Instituto Plantarum.

Tomlinson, P. B. 1961. Anatomy of the monocotyledons. II. Palmae. Clarendon Press: Oxford University Press.

Tomlinson, P. B., Horn, J. W., Fisher, J. B. 2011. The anatomy of palms: Arecaceae-Palmae. USA: Oxford University Press.

Uhl, N. W., Dransfield, J. 1987. Genera palmarum: a classification of palms based on the work of Harold E. Moore, Jr. Lawrence: Kan., Allen Press.

Wilson, E. O. 2012. A Conquista Social da Terra. Editora Schwarcz S. A.: São Paulo. 


\section{$\mathbf{A}_{\text {nexo }}$}

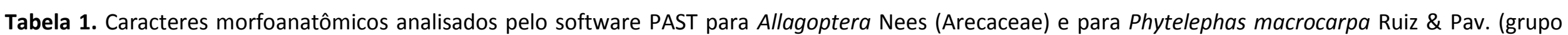

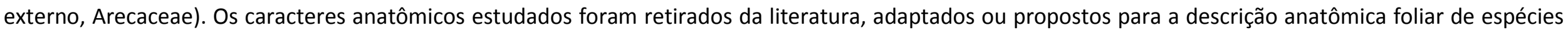

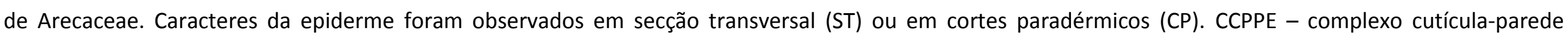

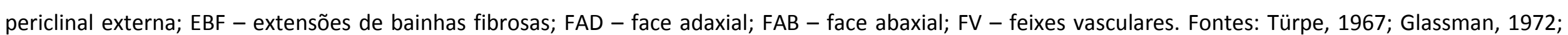

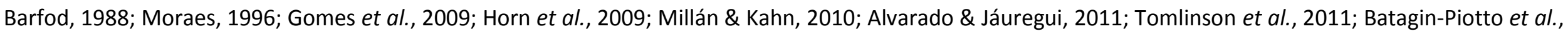
2012; Noraini et al., 2012; Silva, 2012; Noblick, 2013; Martins et al., 2015.

\section{Caracteres}

\section{Estados de caracteres}

\section{FOLHA}

1. Formato da lâmina foliar (ST)

plana (0), convexa adaxial e plana abaxialmente (1) ou convexa adaxial e côncava abaxialmente (2)

2. Sinuosidade da lâmina na FAD (ST) sulcada (0), depressões leves (1) ou sem ondulações (2)

3. Sinuosidade da lâmina na FAB (ST) sulcada (0), depressões leves (1) ou sem ondulações (2)

4. Espessura protoplasto:CCPPE (ST) 2:1 a $1: 1(0), 1: 1$ a $1: 2(1)$ ou $1: 2$ a $1: 4$ (2) 
continuação.

\section{EPIDERME}

\section{Relação FAD:FAB (ST)}

FAD mais espessa que FAB (0), FAD semelhante a FAB (1) ou FAD mais delgada que FAB (2)

6. Localização dos estômatos (ST)

anfiestomático (0), hipoestomático (1) ou epiestomático (2)

7. Localização dos tricomas (ST)

ausentes (0), FAD (1) ou FAB (2)

8. Localização das células buliformes (ST)

ausentes (0), FAD (1) ou FAB (2)

\section{FACE ADAXIAL}

\section{Número de camadas celulares (ST)}

10. Classificação da espessura da epiderme (ST)

\section{- Células comuns da epiderme}

11. Contorno celular (CP)

regular (0), irregular (1) ou ambos (2)

12. Tamanho das células entre si (CP)

semelhante (0) ou variável (1)

\section{Formato (ST)}

14. Relação largura:altura (ST) uniestratificada (0) ou biestratificada (1)

delgada - abaixo de 7,5 $\mu \mathrm{m}$ (0) -, mediana - 7,5 a 10,0 $\mu \mathrm{m}$ (1) - ou espessa - acima de 10,0 $\mu \mathrm{m}$ (2) 
continuação.

\section{- Outras células}

15. Tricomas (ST)

16. Papilas (ST)

17. Células buliformes (ST)

ausentes (0) ou presentes (1)

\section{- Papilas}

18. Formato (CP)

globosas (0) ou outros formatos (1)

19. Número em cada célula (CP)

$1(0)$ ou $2(1)$

\section{FACE ABAXIAL}

20. Número de camadas celulares (ST)

uniestratificada (0) ou biestratificada (1)

21. Classificação da espessura da epiderme (ST)

delgada - abaixo de 7,5 $\mu \mathrm{m}$ (0) -, mediana - 7,5 a 10,0 $\mu \mathrm{m}$ (1) - ou espessa - acima de 10,0 $\mu \mathrm{m}$ (2)

\section{- Células comuns da epiderme}

22. Contorno celular (CP)

23. Tamanho das células entre si (CP) regular (0), irregular (1) ou ambos (2)

semelhante (0) ou variável (1) 


\section{continuação.}

24. Formato (ST)

25. Relação altura:largura - RI (ST)

\section{- Complexo estomático}

26. Classificação (CP)

tetracítico (0) ou outra classificação (1)

27. Região de ocorrência (CP)

RC (0), RI (1) ou ambas (2)

28. Organização na epiderme (CP)

dispostos regularmente (0) ou irregularmente (1) em fileiras estomáticas

29. Distribuição (CP)

distribuídos em 1 (0), 2 (1) ou 3 ou mais (2) fileiras estomáticas

30. Posição das fileiras estomáticas (CP)

organizadas na RI (0) ou sem um padrão específico (1)

31. Câmaras subestomáticas (ST)

ausentes (0) ou presentes (1)

32. Cristas estomáticas (ST)

ausentes (0) ou presentes (1)

33. Cristas subsidiárias (ST)

ausentes (0) ou presentes (1)

\section{Células-guarda}

34. Formato (ST) reniformes (0) ou outros formatos (1) 
continuação.

35. Posição (ST)

proeminentes (0), em depressões (1) ou ao nível das células epidérmicas (2)

\section{Células subsidiárias}

36. Formato das células subsidiárias (ST)

reniformes (0), em forma de "V" (1) ou outros formatos (2)

37. Células subsidiárias ao redor das células guarda (CP) 2 (0), 4 (1) ou 6 (2)

\section{- Outras células}

38. Tricomas (ST)

ausentes (0) ou presentes (1)

39. Papilas (ST)

ausentes (0) ou presentes (1)

40. Células buliformes (ST)

ausentes (0) ou presentes (1)

\section{- Papilas}

41. Formato $(\mathrm{CP})$

globosas (0) ou outros formatos (1)

42. Número em cada célula (CP)

1 (0) ou 2 (1)

\section{Células buliformes}

43. Número de camadas celulares (ST)

1 (0), 2 (1) ou 3 ou mais (2) 
continuação.

44. Formato das células (ST)

45. Altura:largura (ST)

MESOFILO

46. Simetria histológica

dorsiventral clássico (0), dorsiventral gradativo (1) ou homogêneo (1)

47. Variação gradativa nas células do mesofilo ausente (0) ou presente (1)

48. Classificação da espessura do mesofilo delgado - abaixo de $150 \mu \mathrm{m}$ (0) -, mediano - 150 a $250 \mu \mathrm{m}$ (1) - ou espesso - acima de $250 \mu \mathrm{m}(2)$

49. Idioblastos taníferos ausentes (0) ou presentes (1)

50. Ráfides

ausentes (0) ou presentes (1)

\section{PARÊNQUIMA}

- Parênquima clorofiliano

51. Altura:largura das células

2:1 a $3: 1(0), 3: 1$ a $4: 1(1)$ ou $>4: 1(2)$

52. Espaços intercelulares

ausentes (0) ou presentes (1) 
continuação.

\section{- Parênquima paliçádico}

\section{Número de camadas celulares}

$1(0), 2$ (1) ou 3 ou mais (2)

\section{Altura:largura das células}

$<3: 1(0), 3: 1$ a $4: 1$ (1) ou >4:1 (2)

\section{- Parênquima lacunoso}

55. Número de camadas celulares

$1(0), 2$ (1) ou 3 ou mais (2)

56. Formato das células

isodiamétricas (0) ou braciformes (1)

\section{HIPODERME}

57. Número de camadas celulares

1 (0), 2 (1) ou mais de 2 (2)

58. Localização

FAD (0), FAB (1) ou ambas (2)

59. Formato das células na FAD

ovoides (0), circulares a ovoides (1) ou circulares (2)

60. Formato das células na FAB

ovoides (0), circulares a ovoides (1) ou circulares (2)

61. Classificação da espessura (FAD)

delgada - abaixo de 14,0 $\mu \mathrm{m}(0)$-, mediana - 14,0 a 16,0 $\mu \mathrm{m}$ (1) - ou espessa - acima de 16,0 $\mu \mathrm{m}(2)$

62. Classificação da espessura (FAB)

delgada - abaixo de 14,0 $\mu \mathrm{m}(0)$-, mediana - 14,0 a 16,0 $\mu \mathrm{m}(1)$ - ou espessa - acima de 16,0 $\mu \mathrm{m}(2)$ 
continuação.

63. Tamanho relativo FAD:FAB

$>2: 1(0), 2: 1$ a $1: 1(1)$ ou $<1: 1(2)$

\section{Espessura em relação à epiderme}

mais delgada (0), semelhante (1) ou mais espessa (2)

\section{FEIXES VASCULARES (FV)}

65. Ordens de grandeza

$3(0)$ ou $4(1)$

66. Características da bainha perivascular

sem bainha (0), esclerificada contínua (1) ou esclerificada descontínua (2)

\section{- Bainha dos FV}

\section{Formato das células}

ovoides (0) ou circulares (1)

68. Natureza

parenquimática (0) ou esclerenquimática (1)

- Região da nervura principal

69. Proeminência da nervura

não proeminente (0), FAD (1) ou FAB (2)

\section{- FV principal}


continuação.

72. Ligação com a FAD travado (0), semi-travado (1) ou livre (2)

73. Ligação com a FAB travado (0), semi-travado (1) ou livre (2)

74. Localização do protoxilema centro da lâmina (0), voltado para a FAD (1) ou ambas as regiões (2)

75. Localização do metaxilema centro da lâmina (0), voltado para a FAD (1) ou ambas as regiões (2)

76. Número de vasos do metaxilema $\quad 1(0), 2(1)$ ou ambos (2)

77. Divisão da região condutora do floema não dividido (0) ou dividido em secções (1)

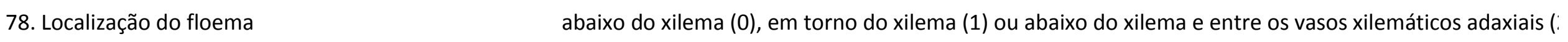

- FV de 1a ordem

79. Formato

circulares (0) ou ovoides (1)

80. Ligação com a FAD

travados (0), semi-travados (1) ou livres (2)

81. Ligação com a FAB

travados (0), semi-travados (1) ou livres (2)

\section{- Bainha dos FV de 1ํa ordem}


continuação.

- FV de 2a ordem
83. Formato
circulares (0) ou ovoides (1)

84. Ligação com a FAD

travados (0), semi-travados (1) ou livres (2)

85. Ligação com a FAB

travados (0), semi-travados (1) ou livres (2)

Bainha dos FV de 2 o ordem

86. Tipo

completa (0) ou incompleta (1)

\section{- FV de 3a ordem}

87. Formato

circulares (0) ou ovoides (1)

88. Ligação com a FAD

travados (0), semi-travados (1) ou livres (2)

89. Ligação com a FAB

travados (0), semi-travados (1) ou livres (2)

\section{Bainha dos FV de 3망em}


continuação.

- FV de 4a ordem
91. Formato
circulares (0) ou ovoides (1)

92. Ligação com a FAD

travados (0), semi-travados (1) ou livres (2)

93. Ligação com a FAB

travados (0), semi-travados (1) ou livres (2)

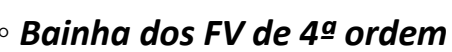

94. Tipo

completa (0) ou incompleta (1)

\section{- FV comissurais}

95. Localização

mais adaxialmente (0), equidistantes (1) ou mais abaxialmente (2)

\section{CÉLULAS ESCLERENQUIMÁTICAS}

\section{- Fibras}

96. Formato predominante dos grupos de fibras

97. Frequência relativa dos grupos de fibras

98. Classificação dos grupos de fibras obtriangulares (0), elíptico deitados (1) ou ambos (2)

raros (0), frequentes (1) ou abundantes (2)

livres no mesofilo (0), unidos à camada superficial (1) ou ambos (2) 


\section{continuação.}

99. Continuidade da camada de fibras

100. Localização dos grupos de fibras

101. Localização em relação à hipoderme

102. Número de fibras em um grupo

camada contínua (0) ou camada descontínua (1)

FAD apenas (0) ou ambas as faces (1)

internamente (0), externamente e adjacentes (1) ou externamente e não adjacentes (2)

103. Fibras do mesofilo e dos feixes vasculares

distintas (0) ou semelhantes (1) entre si

MARGEM FOLIAR

104. Formato $\quad$ arredondada (0) ou inclinada (1)

105. Formato dos grupos de fibras marginais

ovoides e/ou circulares (0) ou triangulares (1)

106. Número de grupos de fibras marginais

$1(0), 2$ ou mais (1) ou ambos (2)

\section{MORFOLOGIA EXTERNA}

\section{Altura da planta}

até 1,3 m (0), 1,3 a 2,0 m (1) ou maior que 2,0 m de altura (2)

108. Hábito da planta

cespitoso (0), solitário (1) ou ambos (2)

109. Habitat

Cerrado (0), Mata Atlântica (1) ou Restinga (2) 


\section{continuação.}
110. Estipe
subterrâneo (0), aéreo (1) ou ambos (2)

\section{- Folha}

111. Número de folhas

até 9 (0), 9 a 14 (1) ou mais de 14 folhas (2)

112. Pilosidade da bainha foliar

glabra (0) ou tomentosa (1)

113. Pilosidade do pecíolo

glabro (0) ou tomentoso (1)

114. Comprimento máximo do pecíolo

até $30,0 \mathrm{~cm}(0), 30,0$ a 45,0 cm (1) ou mais de $45,0 \mathrm{~cm}$ de comprimento (2)

115. Diâmetro máximo do pecíolo

até $1,0 \mathrm{~cm}(0), 1,0$ a $1,5 \mathrm{~cm}$ (1) ou mais de $1,5 \mathrm{~cm}$ de diâmetro (2)

116. Comprimento máximo da raque até $70,0 \mathrm{~cm}(0), 70,0$ a 100,0 cm (1) ou mais de $100,0 \mathrm{~cm}$ de comprimento (2)

\section{Pilosidade da raque}

glabra (0) ou tomentosa (1)

118. Número de segmentos de cada lado

até 60 (0), 60 a 80 (1) ou mais de 80 segmentos de cada lado (2)

119. Inserção dos segmentos

inseridos no mesmo ângulo (0) ou inseridos em ângulos distintos (1)

120. Pilosidade dos segmentos

glabras (0) ou tomentosas (1)

121. Flexuosidade dos segmentos

eretas (0) ou flexuosas (1) 


\section{continuação.}

122. Comprimento máximo dos segmentos basais

123. Largura máxima dos segmentos basais

124. Comprimento máximo dos segmentos medianos

125. Largura máxima dos segmentos medianos

126. Comprimento máximo dos segmentos apicais

127. Largura máxima dos segmentos apicais

128. Presença de ramenta

\section{- Flor}

129. Comprimento da inflorescência

até $70,0 \mathrm{~cm}(0), 70,0$ a $100,0 \mathrm{~cm}$ (1) ou mais de $100,0 \mathrm{~cm}$ de comprimento (2)

130. Comprimento do profilo

131. Comprimento da bráctea peduncular

até $50,0 \mathrm{~cm}(0), 50,0$ a $100,0 \mathrm{~cm}$ (1) ou mais de $100,0 \mathrm{~cm}$ de comprimento (2)

132. Diâmetro da bráctea peduncular

133. Pilosidade da bráctea peduncular até $28,0 \mathrm{~cm}(0), 28,0$ a $35,0 \mathrm{~cm}$ (1) ou mais de $35 \mathrm{~cm}$ de comprimento (2)

até $3,0 \mathrm{~cm}(0), 3,0$ a 4,0 cm (1) ou mais de 4,0 cm de diâmetro (2)

até $30,0 \mathrm{~cm}(0), 30,0$ a $50,0 \mathrm{~cm}$ (1) ou mais de 50,0 cm de comprimento (2)

até $1,0 \mathrm{~cm}(0), 1,0$ a 1,5 cm (1) ou mais de $1,5 \mathrm{~cm}$ de largura (2)

até $30,0 \mathrm{~cm}(0), 30,0$ a $60,0 \mathrm{~cm}$ (1) ou mais de 60,0 cm de comprimento (2)

até $1,0 \mathrm{~cm}(0), 1,0$ a 2,0 cm (1) ou mais de 2,0 cm de largura (2)

até $15,0 \mathrm{~cm}(0), 15,0$ a $30,0 \mathrm{~cm}$ (1) ou mais de $30,0 \mathrm{~cm}$ de comprimento (2)

até $0,5 \mathrm{~cm}(0), 0,5$ a 1,0 cm (1) ou mais de $1,0 \mathrm{~cm}$ de largura (2)

ausente (0) ou presente (1)

glabra (0) ou tomentosa (1) 
continuação.

\section{- Flor estaminada}

\section{Comprimento}

até 5,0 mm (0), 5,0 a 10,0 mm (1) ou mais de 10,0 mm de comprimento (2)

135. Comprimento do pedicelo

ausente (0), 1,0 $\mathrm{mm}$ ou menor (1) ou mais de 1,0 $\mathrm{mm}$ de comprimento (2)

136. Inserção do pedicelo

ausente (0), inserido paralelamente (1) ou inserido perpendicularmente (2)

137. Conação das sépalas

livres (0), conadas (1) ou conadas na base (2)

138. Pilosidade das sépalas

glabras (0) ou com tricomas (1)

139. Consistência das sépalas

coriáceas (0) ou membranáceas (1)

140. Prefloração das pétalas

valvadas (0) ou imbricadas (1)

\section{Conação das pétalas}

livres (0), conadas (1) ou conadas na base (2)

142. Pilosidade das pétalas

glabras (0) ou com tricomas (1)

143. Consistência das pétalas

coriáceas (0) ou membranáceas (1)

144. Número de estames

até 10 (0), 10 a 20 (1) ou mais de 20 estames (2)

145. Pistilódio

ausente (0), simples (1) ou trífido (2) 
continuação.

\section{- Flor pistilada}

146. Presença de pedicelo

147. Conação das sépalas

148. Pilosidade das sépalas

149. Conação das pétalas

150. Pilosidade das pétalas

151. Conspicuidade do estaminodio

152. Estigma

\section{- Fruto e semente}

153. Comprimento do fruto

até $2,0 \mathrm{~cm}(0), 2,0$ a $4,0 \mathrm{~cm}$ (1) ou mais de $4,0 \mathrm{~cm}$ de comprimento (2)

1 (0) ou mais de 1 (1)

154. Número de sementes séssil (0) ou pedicelada (1)

livres (0), conadas (1) ou conadas na base (2)

glabras (0) ou com tricomas (1)

livres (0), conadas (1) ou conadas na base (2)

glabras (0) ou com tricomas (1)

conspícuo (0) ou inconspícuo (1)

capitado (0) ou trífido (1) 
